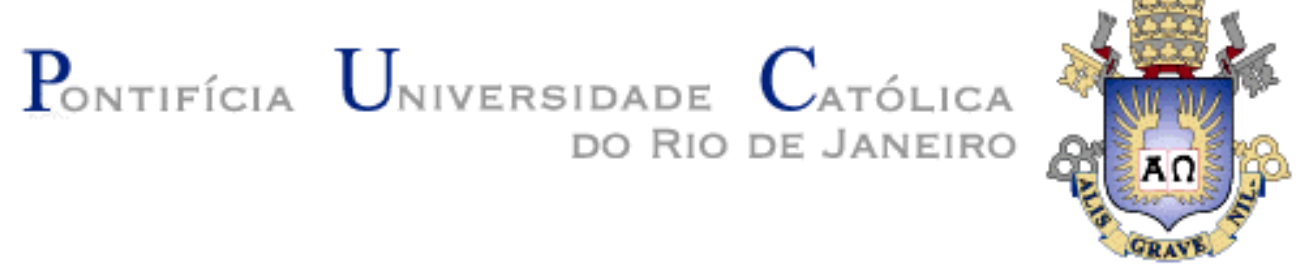

Vivian Peuker Sardon Steinhäuser

\title{
Institutional Effects on the Internationalization of Entrepreneurial Firms
}

Tese de Doutorado

Thesis presented to the Programa de Pósgraduação em Administração de Empresas of PUC-Rio in partial fulfillment of the requirements for the degree of Doutor em Administração de Empresas.

Advisor: Profa. Angela Maria Cavalcanti da Rocha Co-Advisor: Prof. Hartmut Holzmüller 


\section{Vivian Peuker Sardon Steinhäuser}

\section{Institutional Effects on the Internationalization of Entrepreneurial Firms}

Thesis presented to the Programa de Pós-graduação em Administração of PUC-Rio in partial fulfillment of the requirements for the degree of Doutor em Ciências Administração de Empresas. Approved by the undersigned Examination Committee.

Prof. Angela Maria Cavalcanti da Rocha

Advisor

PUC-Rio

Prof. Hartmut Holzmüller Co-Advisor

TU Dortmund

Prof. Fabio de Oliveira Paula

PUC-Rio

Prof. Luis Fernando Hor-Meyll Alvares

PUC-Rio

Prof. Gilberto Figueira da Silva ML-Consultoria

Prof. Otávio Henrique dos Santos Figueiredo

UFRJ

Prof. Renato Dourado Cotta de Mello

UFRJ

Rio de Janeiro, 29 de abril de 2021. 
All rights reserved.

\section{Vivian Peuker Sardon Steinhäuser}

Graduated in Product Design at Pontifícia Universidade Católica do Rio de Janeiro in 1998 and obtained her M.Sc. Degree in Business Administration from the at Pontifícia Universidade Católica do Rio de Janeiro in $2016 .$.

Bibliographic data

Steinhäuser, Vivian Peuker Sardon
Institutional effects on the internationalization
of entrepreneurial firms / Vivian Peuker Sardon
Steinhäuser ; advisor: Angela Maria Cavalcanti da
Rocha ; co-advisor: Hartmut Holzmüller. - 2021.
$145 \mathrm{f}$; $30 \mathrm{~cm}$
Tese (doutorado)-Pontifícia Universidade
do Rio de Janeiro, Departamento de
Católica
Administração, 2021.
Inclui bibliografia
1. Administração - Teses. 2. Negócios
internacionais. 3. Internacionalização de empresas
empreendedoras. 4. Instituições do país de origem. 5 .
Estudos de casos. I. Rocha, Angela Maria Cavalcanti
da. II. Holzmüller, Hartmut. III. Pontifícia Universidade
Católica do Rio de Janeiro. Departamento de
Administração. IV. Título.

CDD: 658 


\section{Aknowledgments}

To Alexandre, Ana and Eduarda for their support and for being the north of my journey.

To Angela, for her generosity and experience.

To Hartmut for opening his house for me and my family.

To the Technische Universität Dortmund for your support in such an adverse period, middle in the Pandemic.

To all professors and staff at PUC-Rio for your guidance and for always being open to help. You are part of my family.

Finally to PUC-Rio, for being my second home and my personal, professional and academic reference since graduation.

his work was carried out with the support of the Coordination for the Improvement of Higher Education Personnel - Brazil (CAPES) - Financing Code 001. 


\section{Abstract}

Steinhäuser, Vivian Peuker S.; da Rocha, Angela (Advisor); Holzmüller, Hartmut (co-advisor). Institutional Effects on the Internationalization of Entrepreneurial Firms. Rio de Janeiro, 2021. 145p. Tese de Doutorado Departamento de Administração, Pontifícia Universidade Católica do Rio de Janeiro.

This thesis focuses on a deeper understanding of different aspects of the effects of home country institutions on the firm internationalization process of mature entrepreneurial firms. It is composed by a bibliometric review of the literature on international entrepreneurship that uses institutional theory, covering the period between 2008 and 2020, and two in-depth longitudinal case studies. In the bibliometric review, a total of 65 articles were selected. The analysis proceeded in two steps. First, a descriptive analysis was performed to characterize the papers in terms of their nature and content. Second, the bibliographic coupling technique, using the VOS Viewer software, was employed to identify theoretical trends in the field. The 13-year period was divided into three periods of four years. The empirical part of this thesis consists of two case studies. The two separate cases helped to achieve a deeper understanding of different aspects of the effects of home country institutions on the firm internationalization process of mature entrepreneurial firms.

\section{Keywords}

International Business; Internationalization of entrepreneurial firms; Institutions of the home-country; Case Studies 


\section{Resumo}

Steinhäuser, Vivian Peuker S.; da Rocha, Angela (Orientadora); Holzmüller, Hartmut (Co-orientador). Efeitos das instituições na internacionalização de empresas empreendedoras. Rio de Janeiro, 2021. 145p. Tese de Doutorado - Departamento de Administração, Pontifícia Universidade Católica do Rio de Janeiro.

Esta tese busca uma compreensão mais profunda dos diferentes aspectos dos efeitos das instituições do país de origem no processo de internacionalização de empresas empreendedoras maduras. $\mathrm{O}$ estudo é composto por uma revisão bibliométrica da literatura sobre empreendedorismo internacional que utiliza a teoria institucional, abrangendo o período de 2008 a 2020, e dois estudos de caso longitudinais aprofundados. Na revisão bibliométrica, foram selecionados 65 artigos. A análise ocorreu em duas etapas. Primeiramente, foi realizada uma análise descritiva para caracterizar os artigos quanto à sua natureza e conteúdo. Em segundo lugar, a técnica de acoplamento bibliográfico, utilizando o software VOS Viewer, foi empregada para identificar tendências teóricas na área. O período de 13 anos foi dividido em três períodos de quatro anos. A parte empírica desta tese consiste em dois estudos de caso. Os dois casos separados chegam a uma compreensão mais profunda dos diferentes aspectos dos efeitos das instituições do país de origem no processo de internacionalização de empresas empreendedoras maduras

\section{Palavras Chave}

Negócios Internacionais; Internacionalização de empresas empreendedoras; Instituições do pais de origem; Estudos de Casos 


\section{Table of Contents}

1 Introduction 11

$\begin{array}{ll}\text { Abstract } & 11\end{array}$

1.1 Focus of the Thesis 11

$\begin{array}{ll}1.2 \text { Research Questions } & 13\end{array}$

$\begin{array}{ll}1.3 \text { Organization of the Thesis } & 14\end{array}$

1.4 References 15

2 Paper 1 - Institutional Theory and International Entrepreneurship:

$\begin{array}{ll}\text { A Review } & 17\end{array}$

$\begin{array}{ll}\text { Abstract } & 17\end{array}$

$\begin{array}{ll}2.1 \text { Introduction } & 17\end{array}$

2.2 Institutional Theory 20

2.3 Institutional Theory and Entrepreneurship Research 23

2.4 Method 26

2.5 Descriptive Results 29

2.6. Bibliographic Coupling (BC) 33

2.7 Discussion 43

2.8 Final Remarks $\quad 45$

$\begin{array}{ll}2.9 \text { References } & 46\end{array}$

3 Paper 2 - Institutional Environment, Liabilities, and Legitimacy The Case of a Brazilian Information Technology Firm 58

Abstract 58

3.1 Introduction $\quad 58$

3.2 Theoretical Background 60

3.2.1 Institutional voids $\quad 61$

3.2.2 Internationalization and the institutional environment 64

3.2.3 Liabilities of foreignness, emergingness and outsidership 66

3.2.4 Legitimacy $\quad 67$

$\begin{array}{ll}3.3 \text { Method } & 70\end{array}$

3.4 The Brazilian Information Technology Industry 72

3.5 The Case Stefanini IT Solutions 73

$\begin{array}{ll}3.5 .1 \text { Background } & 73\end{array}$ 
3.5.2 Internationalization trajectory

3.5.3 Entry and operations in the United States 81

3.5.4 Institutions in Brazil 85

3.6 Discussion 87

3.7 Final Remarks 92

3.8 References 93

4 Paper 3 - Institutional Distance and Perceived Institutional Familiarity

- A Case Study of a German Information Technology Company 101

Abstract 101

4.1 Introduction 101

4.2 Theoretical Background 103

4.2.1 Institutional distance 103

4.2.2 The role of institutional distance in IB decisions 106

4.2.3 Perceived institutional familiarity 108

4.3 Method 110

4.4 The Technology Information Industry in Germany and the Dortmund Area 112

4.5 The Case of Adesso SE $\quad 114$

4.5.1 Background 114

4.5.2 Internationalization trajectory $\quad 117$

4.5.3 Entry into Turkey and the creation of Adesso Turkey 119

4.5.4 Comparison of the institutional environments of Turkey and Germany 123

4.6 Discussion 126

4.7 Final Remarks 129

4.8 References 131

4.9 Appendix 1 - Hofstede's Cultural Dimensions - Other Countries 136

5 Conclusion 141

5.1 Thesis Overview and Cross-Case Comparison 141

5.2 Contributions of the Study 144

5.3 Suggestions for Future Research 145

5.4 References 145 


\section{List of Tables}

Chapter 2 (Paper 1)

Table 1. Research parameters

Table 2. Journals by number of articles published 39

Table 3. Types of Articles $\quad 30$

Table 4. Characteristics of the studies reviewed 31

Table 5. Most often cited articles 32

Table 6. Summary of Clusters 42

Chapter 3 (Paper 2)

Table 1 - Institutional Voids $\quad 62$

Table 2 - Liabilities and Assets of Foreignness 66

Table 3 - Dimensions of Legitimacy 68

Table 4 - Dimensions of Legitimacy and Strategies to Gain Legitimacy 69

Table 5 - Characteristics of the Case Selected 71

Table 6 - Summary of data sources $\quad 71$

Table 7 - Interviewee Profile $\quad 72$

Table 8 - Stefanini IT Solutions data (estimated) 74

$\begin{array}{ll}\text { Table } 9 \text { - Stefanini IT Time Line } & 74\end{array}$

Table 10 - Stages in Stefanini's Internationalization Process 87

Table 11 - Issues and corresponding liabilities faced by Stefanini in the 88 U.S.

Table 12 - Strategies for legitimation employed by Stefanini in the U.S. 90 according to the stages of firm internationalization

Chapter 4 (Paper 3)

Table 1 - Definitions of institutional distance according to the literature $\quad 104$

Table 2 - Hofstede's Cultural Dimensions 105

Table 3 - Characteristics of the selected case 111

Table 4 - Interviewee Profile 112

Table 5 - Adesso SE data 115

Table 6 - Adesso SE Time Line $\quad 116$

Table 7 - Adesso SE's Internationalization Trajectory 118

Table 8 - WGI Indicators of Regulatory and Normative Distance between $\quad 124$

Germany and Turkey

Table 9 - Economic Freedom in Germany and in Turkey 124

Table 10 - Reasons to Enter Turkey despite Large Institutional Distance 126

Table 11 - Perceived Differences between Germany and Turkey 127

Chapter 5 (Conclusion)

Table 1 - Comparison of the characteristics of Stefanini IT and Adesso SE 142 


\section{List of Figures}

Chapter 2 (Paper 1)

Figure 1 - Thematic clusters for the sub-period 2008-2011 34

Figure 2 - BC of the sub-period 2012-2015 (five clusters) 37

Figure 3 - BC of the sub-period 2016-2020 39

Chapter 3 (Paper 2)

Figure 1-Sales Growth (in billions of reals) $\quad 74$

Chapter 4 (Paper 3)

Figure 1 - Sales growth (in million euros) 116

Figure 2 - Comparison of the Hoftsede Dimensions between Germany and
Turkey

Figura 1a - Comparativo de Hoftsede, dos países de entrada da Adesso 136

SE (Alemanha e Suiça)
Figura $1 \mathrm{~b}$ - Comparativo de Hoftsede, dos países de entrada da Adesso

SE (Alemanha e Reino Unido) 137

Figura 1c-Comparativo de Hoftsede, dos países de entrada da Adesso
SE (Alemanha e Áustria)

Figura 1d-Comparativo de Hoftsede, dos países de entrada da Adesso SE 138

(Alemanha e Estados Unidos)
Figura 1e - Comparativo de Hoftsede, dos países de entrada da Adesso

SE (Alemanha e Espanha)

Figura $1 f$ - Comparativo de Hoftsede, dos países de entrada da Adesso SE (Alemanha e Bulgaria)

Figura $1 \mathrm{~g}$ - Comparativo de Hoftsede, dos países de entrada da Adesso

SE (Alemanha e Hungria)

Figura 1h - Comparativo de Hoftsede, dos países de entrada da Adesso

SE (Alemanha e Holanda) 
1

\section{Introduction}

\section{Abstract}

This thesis focuses on a deeper understanding of different aspects of the effects of home country institutions on the internationalization process of mature entrepreneurial firms. It is composed by a bibliometric review of the literature on international entrepreneurship that uses institutional theory, covering the period between 2008 and 2020, and two in-depth longitudinal case studies. In the bibliometric review, a total of 65 articles were selected. The analysis proceeded in two steps. First, a descriptive analysis was performed to characterize the papers in terms of their nature and content. Second, the bibliographic coupling technique, using the VOS Viewer software, was employed to identify theoretical trends in the field. The 13-year period was divided into three periods of four years. The empirical part of this thesis consists of two case studies. The two separate cases helped to achieve a deeper understanding of different aspects of the effects of home country institutions on the firm internationalization process of mature entrepreneurial firms.

\section{1}

Focus of the Thesis

This thesis focuses on three relevant issues in International Business (IB): home-country institutions (theme); entrepreneurial firms (unit of analysis) and emerging and developed markets (context). The study intends to contribute to the IB literature by investigating the effects of home country institutions on entrepreneurial firms' internationalization process. The concept of entrepreneurial firms in this thesis is based on Oviatt and McDougall (2000) who claim that international entrepreneurship applies to any entrepreneurial firm regardless of 
age or time of internationalization. The theoretical perspective adopted is institutional theory.

Home country factors, such as infrastructure, education, politics, bureaucracy, corruption, public policies, support programs, and taxes, influence not only the institutional context of the firm but also its growth and diversification strategies. When a firm decides to adopt internationalization as a diversification strategy, its foreign entry mode decision is directly related to the factors present in its country of origin (Laufs \& Schwens, 2014). Firms from emerging economies are particularly vulnerable to institutional change in their home countries (Cheng \& Yu, 2008). The literature offers two main explanations for the internationalization of emerging market firms: (i) the government promotion view, that is, when a firm internationalizes due to several support mechanisms offered by the home country government; and (ii) the "institutional escapism view", when a firm internationalizes to escape institutional voids of the home country (Li \& Ding, 2017, p.128). In the specific case of Brazil, a severe recession, combined with political turmoil since late 2014, has challenged the success, continuity and survival of many entrepreneurial firms, a situation that was followed by the pandemic and its effects. As a result, many entrepreneurial firms closed or went bankrupt, and several others were compelled to expand their activities abroad. Other firms that were already internationalized were less impacted by the crisis.

Entrepreneurial firms in emerging countries suffer from several constraints, such as regulations and lack of support to internationalize, when compared to their counterparts in developed countries. In spite of this, there is a surprising lack of studies that investigate the effects of emerging country institutions on the internationalization decision of entrepreneurial firms (Laufs \& Schwens, 2014). The comparison of emerging and developed countries can help scholars to understand the differences of effects that home country institutions may have on a firm's strategy, based on different contexts. In addition, international entrepreneurship scholars have not given much attention to entrepreneurial firms that internationalize later in their lifecycle. Quite the contrary, most of the international entrepreneurship literature focuses on international new ventures, with few studies looking at entrepreneurial firms that internationalize later in their lifecycle (Coviello, McDougall \& Oviatt, 2011; 
Covin \& Miller, 2013; Da Rocha, Moraes \& De Mello, 2019; Naldi, Achtenhagen \& Davidsson, 2015).

\section{2 \\ Research Questions}

The present thesis consists of three papers: a bibliometric review and two empirical studies using the case method of investigation. The first paper is a bibliometric review of the international entrepreneurship literature that uses institutional theory. This paper maps the research area examined in this study. Although it goes beyond the topics examined specifically in the second and third paper, the bibliometric review provides a broad understanding of the issues that have been considered in the field of international entrepreneurship under the umbrella of institutional theory. The bibliometric review sought to answer the following research question:

- What are the main themes studied in international entrepreneurship using an institutional perspective?

The second paper consists of a case study that investigates how home country institutions influence the internationalization process of a mature entrepreneurial firm from an emerging country, Brazil. Specifically, the focus of the case study is on how this firm has overcome national institutional voids (Khanna \& Palepu, 1997; Khanna, Palepu \& Sinha, 2005) and built legitimacy (Aldrich \& Fiol, 1994; Zhang et al., 2020) in a high-quality institutional context. Differences between the institutional environments were measured using indexes such as the World Governance Indicators of the World Bank and the Economic Freedom Index (EFI) of the Heritage Foundation. The case examined is Stefanini IT Solutions, one of the leading entrepreneurial firms and one of the most internationalized in the Brazilian software industry. The research questions addressed in this study are:

- How can an entrepreneurial firm from an emerging market overcome national institutional voids by expanding internationally, particularly to countries of high institutional quality? 
- How does the firm employ specific legitimation practices to develop its cross-border activities?

The third paper investigates a firm immersed in a high-quality institutional context in order to unveil its internationalization process to an emerging country with a weaker institutional context. The paper explores the interplay between the constructs of institutional distance (Kostova et al., 2020) and of perceived institutional familiarity (Schwens \& Kabst, 2011) as the basis to understand how a mature entrepreneurial firm from an advanced economy (Germany) enters and operates in a country with a lower quality institutional environment (Turkey). The case studied is that of Adesso SE, a German firm that customizes software solutions, which is presently one of the leading companies in industry-specific processes in Central Europe. The Adesso SE case was prepared while the researcher was on an international exchange program as a research visiting fellow at the Technical University of Dortmund, in Germany. The research questions addressed in this study are:

- How is the interplay between a high institutional distance between the headquarters and a subsidiary, and the perceived institutional familiarity with some aspects of the host environment by the entrepreneurs leading the firm?

- How does institutional distance and perceived familiarity impact the decisions along the subsidiary's trajectory in time?

\section{3}

\section{Organization of the Thesis}

The thesis is organized as following: after this introduction, the main theoretical background is concentrated in the first paper, the bibliometric review, presented in chapter 2. Chapter 3 consists of the second paper, focusing on institutional voids, liabilities of foreignness, emergingness and outsidership, and the responses of the firm to these challenges in order to gain legitimacy in a highquality institutional environment. Chapter 4 examines the interplay between institutional distance and perceived institutional familiarity in the context of vastly 
different institutional environments. Chapter 5 provides an overview of the conclusions of this thesis.

\section{4 \\ References}

Aldrich, H. E., \& Fiol, C. M. (1994). Fools rush in? The institutional context of industry creation. Academy of Management Review, 19(4), 645-670.

Cheng, H. L., \& Yu, C. M. J. (2008). Institutional pressures and initiation of internationalization: Evidence from Taiwanese small and medium-sized enterprises. International Business Review, 17(3), 331-348.

Coviello, N. E., McDougall, P. P., \& Oviatt, B. M. (2011). The emergence, advance and future of international entrepreneurship research-An introduction to the special forum. Journal of Business Venturing, 26(6), 625-631.

Covin, J G. \& Miller, D. (2014). International entrepreneurial orientation: Conceptual considerations, research themes, measurement items, and future research directions. Entrepreneurship Theory and Practice, 38(1), 11-44.

Da Rocha, A., Moraes, S.T.A., \& De Mello, R. C. (2020). Entrepreneurial behavior of mature firms in internationalization: evidence from a high-tech industry. Base Revista de Administração e Contabilidade da Unisinos, 16(4), 523551.

Economic Freedom Index (EFI)(2021). Heritage Foundation. Available at: https://www.heritage.org/index/about

Khanna, T., \& Palepu, K. (1997). Why focused strategies may be wrong for emerging markets. Harvard Business Review, 75(4): 41-51.

Khanna, T., Palepu, K. G., \& Sinha, J. (2005). Strategies that fit emerging markets. Harvard Business Review, June, 2-18.

Kostova, T., Beugelsdijk, S., Scott, W. R., Kunst, V. E., Chua, C. H., \& van Essen, M. (2020). The construct of institutional distance through the lens of different institutional perspectives: Review, analysis, and recommendations. Journal of International Business Studies, 51(4), 467-497.

Laufs, K., \& Schwens, C. (2014). Foreign market entry mode choice of small and medium-sized enterprises: A systematic review and future research agenda. International Business Review, 23(6), 1109-1126. 
Li, F., \& Ding, D. (2017). The dual effects of home country institutions on the internationalization of private firms in emerging markets: Evidence from China. Multinational Business Review, 25(2), 128-149.

Naldi, L., Achtenhagen, L., \& Davidsson, P. (2015). International corporate entrepreneurship among SMEs: A Test of Stevenson's Notion of Entrepreneurial Management. Journal of Small Business Management, 53(3), 780-800.

McDougall, P. P., \& Oviatt, B. M. (2000). International entrepreneurship: the intersection of two research paths. Academy of management Journal, 43(5), 902-906.

World Bank’s World Governance Indicators (WGI) (2019), World Bank’s. Available at: https://info.worldbank.org/governance/wgi/Home/Reports

Zhang, J., Deephouse, D.L., Van Gorp, D., \& Ebbers, H. (2020). Individuals' perceptions of the legitimacy of emerging market multinationals: Ethical foundations and construct validation. Journal of Business Ethics. Published online. 
2

$\begin{array}{lllll}\text { Paper } & 1 & - & \text { Institutional Theory and International } \\ \text { Entrepreneurship: A Review } & & \end{array}$

\section{Abstract}

This paper presents a bibliometric review of the empirical literature in international entrepreneurship that uses institutional theory, covering the period from 2008 to 2020. This time frame was based on Su, Zhai and Karlsson's (2017) review of institutional theory in entrepreneurship research. These authors have indicated that institutional theory only became fully accepted in entrepreneurship research after 2008. A total of 65 articles were selected. The analysis proceeded in two steps. First, a descriptive analysis was performed to characterize the papers in terms of their nature and content. Second, the bibliographic coupling technique, using the VOS Viewer software, was employed to identify theoretical trends in the field. The 13-year period was divided into three periods of four years. The results show a high proportion cross-country of empirical, quantitative, crosscountry studies using existing datasets, comparing characteristics of entrepreneurship in countries with different institutional profiles. However, recent studies seem to dedicate a growing attention to institutional issues impacting the internationalization of entrepreneurial firms.

\section{1}

Introduction

Although institutional theory is a relatively recent theoretical perspective used by international business (IB) scholars (Henisz \& Delios, 2000; Henisz \& Swaminathan, 2008), compared to other dominant theoretical approaches such as the international process model, internalization theory or the Eclectic Paradigm, it 
has "strongly impacted" the field (Scott, 2010, p.vii), becoming "one of the leading perspectives in IB strategy" (Peng \& Khoury, 2008, p.257). Dunning and Lundan (2008, p.577) contend, however, that "aspects of institutional analysis have been implicit in the existing theories of international business for a long time, $[\ldots]$ although this work may not have appeared under an institutional label." Typical examples are the studies on the role of culture in IB (e.g., Kogut \& Singh, 1988; Tung \& Verbeke, 2010) and those that have examined the impact of perceived political risk on corporate decisions (e.g. Kobrin, 1982; Tallman, 1988). Peng, Wang and Jiang (2008) argue that institutional theory adds "a third leg" to the "strategy tripod" (comprised also by the resource-based view and industrial organization theory), while Dunning and Lundan (2008) claim that this perspective helps to combine the macro and micro levels and formal and informal institutions into a theoretical framework.

In fact, the importance of considering the institutional environment is critical for firms that operate internationally, compared with those that operate only domestically, because the first need to adapt beliefs, structures, practices and routines developed in the home country environment to new institutional environments, which invariably differ from the original one, although the degree of difference may vary (Henisz \& Delios, 2000; Henisz \& Swaminathan, 2008). The easiness or difficulty to perform these changes depends on the similarities between the home country and the host country institutional environment (institutional distance) in key aspects to the firm's operations. From the firm's perspective, managers need to identify and deal with the differences they encounter; failure to do so implies higher costs of operations and, eventually, exiting (e.g., Dhanaraj \& Beamish, 2009; Demirbag, Apaydin, \& Tatoglu, 2011).

IB scholars have initially concentrated their attention in characteristics of the host country, particularly due to their focus on multinational enterprises (MNEs). Part of this literature examines how differences in the institutional environment between home and host country in the regulatory, normative and cognitive dimensions impact international strategies (e.g. Konara \& Shirodkar, 2018; Phillips, Tracey \& Karra, 2009). More recently, the IB literature has given special attention to emerging markets (e.g., James, Sawant \& Bendickson, 2020; 
Rottig, 2016). Surdu, Mellahi and Glaister (2018), reviewing the literature on entry modes of emerging market multinational enterprises (EMNEs), find that a growing number of studies have adopted institutional theory as the main theoretical perspective, while several others have used multiple perspectives, one of which is institutional theory. Kostova and Marano (2019, p.99) concur and expand this argument, stating that "the literature on emerging markets and emerging market firms is dominated by the institutional perspective."

Despite the substantial growth in IB studies using institutional theory, researchers have given limited attention to smaller firm internationalization, and even less to entrepreneurial firms' internationalization. Yet, when compared to large, established firms, entrepreneurial firms are even more sensitive to the institutional context. In addition, entrepreneurial firms from emerging economies are particularly vulnerable to institutional change in their home countries (Cheng \& Yu, 2008). Contrasted to their counterparts in developed countries, they suffer from additional constraints to their internationalization, such as regulatory and bureaucratic barriers and lack of support to internationalize.

This paper presents a bibliometric review of the empirical literature that uses institutional theory to examine the internationalization of entrepreneurial firms, covering the period from 2008 to 2020. Other relevant literature reviews on the use of institutional theory as a theoretical perspective have either covered the whole field of entrepreneurship (e.g., Bruton, Ahlstrom \& Li, 2010; Su, Zhai, \& Karlsson, 2017), or have examined several theoretical perspectives adopted in international entrepreneurship, one of which is institutional theory (e.g., Jones, Coviello \& Tang, 2011; Peiris, Akoorie \& Sinha, 2012). Only one previous literature review examined the same issue addressed in this paper but covered only articles published until 2008 (Szyliowicz \& Galvin, 2010). Aiming to filling this gap, the present study sought to answer the following research question: What are the main themes studied in international entrepreneurship using an institutional perspective?

The paper proceeds as follows. The next section presents a brief review of institutional theory and the main strands that appear under this label. The subsequent section examines several reviews on entrepreneurship and 
international entrepreneurship to identify how they have detected the use of institutional theory in these literatures. Then, the methodology adopted in this paper is described. Finally, the findings from a bibliometric review are presented, followed by a discussion of the findings and the final considerations.

\section{2 Institutional Theory}

Institutional theory has attracted the interest of scholars from several fields (Scott, 2005) as a powerful theoretical perspective to examine the environment in which organizations operate. Yet, because of the different approaches that coexist in the literature, this theoretical perspective presents different definitions of basic concepts, such as institutions and institutionalization, and "substantial variation among approaches" (Scott, 1987, p.493). While all the different approaches concur on the impacts of institutions on organizations, "there is little agreement on how, why and where [...] such effects occur" (Scott, 1987, p.501). Scott (1987) pointed out, however, to a certain degree of convergence among the various views, concerning the understanding that organizations of all kinds operate in an institutional environment, which not only defines the boundaries within which they have to act, but also is characterized by multiplicity, diversity, and variation. Three decades later, Kostova, Roth and Dacin (2008) also claim that research on MNCs using institutional theory could benefit by integrating different approaches.

Authors diverge on the number of different streams of institutional theory. Scott (1987) examines four approaches to institutional theory, while Hotho and Pedersen (2012) consider three strands in institutional theory: new institutional economics, new organizational institutionalism, and comparative institutionalism. Kostova and Marano (2019, p.100) recognize "at least" three different strands, which are similar to Hotho and Pedersen's (2012). Friel (2017) warns that even within one of these strands - institutional economics - there are different approaches and levels of analysis, and Kingston and Caballero (2009) offer a 
comparison of several theories of institutional change, one of the issues examined in institutional economics.

Institutional economics conceptualizes institutions as "humanly devised constraints that structure political, economic and social interaction", conceived "to create order and reduce uncertainty in exchange" (North, 1990, p.97). They can be purposefully established, as in the case of a country's constitution, or they can evolve over time. North recognizes two types of institutions: informal (including traditions, conventions, taboos, and codes of behavior) and formal (such as regulations, laws, and other types of formal rules). They can be used to forbid certain actions, or to limit what is considered acceptable to do. They are "the rules of the game" (North, 1991, p. 4). Acknowledging the importance of the understanding of the institutional environment, Koning, Mertens and Roosenboom (2018) claim that there is still limited knowledge in IB about the forces that drive institutional change. Institutional economics has looked at the institutional quality of a country and its impact on areas such as capital mobility (Younas, 2009), foreign direct investment (Masron, 2017; Ullah \& Khan, 2017), trade (Álvarez et al., 2018), and innovation (Tebaldi \& Elmslie, 2013), among other issues.

A related concept is "institutional voids" (Khanna \& Palepu, 1997), which refers to the weakness of formal institutions, typical of less developed economies. Such institutional deficiencies can create constraints to the development of firms. Institutional voids are also an obstacle for firms entering new markets with weak institutions because transactions costs will be higher there than in markets with a strong institutional environment. Researchers in institutional economics have also addressed the issue of institutional change (e.g., Bush, 1987; North, 1998), including economic liberalization, and other pro-market reforms. According to North (1991, p.6-7), institutional change is a complex process, which "can be a consequence of changes in rules, in informal constraints, and in kinds and effectiveness of enforcement." In his view, changes in the institutional environment tend to be incremental, not disruptive, particularly those concerning informal institutions. Institutions differ from organizations; while the first determine the economic opportunities available to organizations, the latter are created to exploit the opportunities. There is a "symbiotic relationship" between 
organizations and institutions; as organizations evolve, institutions change. In fact, there is a sort of lock-in between them, which may make it difficult for organizations from a given institutional environment to operate efficiently in another.

Organizational institutionalism sees institutions as "regulative, normative, and cognitive structures and activities that provide stability and meaning to social behavior" (Scott, 1995, p.33). These structures are the "pillars" of institutionalism. The regulatory pillar can be described as the rules, formal and informal, and their enforcement mechanisms that constrain the behavior of individuals and organizations. An organization suffers coercive pressures when it must follow rules or regulations imposed by institutions (e.g. environmental regulations, consumer protection laws) or by cultural practices. Government and state often represent the coercive pressures that enforce regulatory execution. The normative pillar consists of moral and cultural constraints that reflect a society's values and beliefs. Some normative pressures are applicable to all members of a society and others just for members of a group or persons with the same function (Scott, 1995). For example, normative pressures happen when members of an occupation define and institutionalize their work methods and accepted practices. Other normative pressures include formal university education and professional networks (DiMaggio \& Powell, 1983). Finally, the cognitive pillar refers to how individuals perceive reality. It is centered in the individual actor and is a subjective outcome of the interpretation of reality by the actor. The three pillars are considered "the bases of social order", and although independent "they most often appear in varying combinations" (Scott, 2010, p.7). An important concept in this strand is that of organizational field, in contrast with individual organizations. An organizational field is composed by "organizations that, in the aggregate, constitute a recognized area of institutional life," including suppliers, competitors, consumers, related government agencies and other relevant organizations (Di Maggio \& Powell, 1983, p.148). For an organizational field to exist several conditions are necessary, such as constant interaction among players and common awareness of their linkages, among others. However, the boundaries of an organizational field are permeable to different ideas, and models of behavior, 
opening possibilities of change; actors embedded in an organizational field may influence the adoption of new structures and practices (Hotho \& Perdersen, 2012).

The third strand is comparative institutionalism, which "seeks to describe, compare and explain the diversity, change and persistence of distinct systems of economic coordination and control" (Hotho \& Perdersen, 2012, p. 247). It departs from the assumption that institutions, particularly in developed economies, reinforce each other and are interdependent. Different institutional environments explain the diversity of organizational forms, structures, and practices.

\section{3}

\section{Institutional Theory and Entrepreneurship Research}

Researchers on entrepreneurship have increasingly used institutional theory (Bruton, Ahlstrom \& Li, 2010). Several literature reviews have contributed to map the use of institutional theory in entrepreneurship research and provide future research directions. According to Bruton, Ahlstrom and Li (2010), three main themes stand out in the literature on institutional theory and entrepreneurship: (i) the institutional environment and how it defines and limits entrepreneurial opportunities; (ii) legitimacy issues, that is, how a venture must engage in activities to legitimize its existence; and (iii) institutional entrepreneurship, that is, arrangements to create new institutions or to change existing ones. The authors identify three major shortcomings in this literature: (i) considering only one perspective of institutional theory; (ii) examining culture only, and not considering other factors; and (iii) concentrating the analysis on only one country, since it is difficult to evaluate the impact of institutions in a single country. In addition, Bruton, Ahlstrom and Li (2010, p.421) argue that institutional theory has proven "to be particularly powerful in examining international related topics" in entrepreneurship research.

A more recent review of institutional theory in the entrepreneurship literature (Su, Zhai, \& Karlsson, 2017, p. 505) claims that institutional theory "has long been used [...] to account for environmental influences on entrepreneurship in general and start-up rates and legitimizing strategies in specific." The authors 
point out that the first article examined in their review applying this theoretical perspective to entrepreneurship was published in 1992, but the number of articles per year remained quite low until "a leap" in 2008 in the number of publications. The authors identified three phases of entrepreneurship research using institutional theory: a "conceptual phase" (1992-2000), with only eight articles published; an "exploration phase" (2001-2007), with altogether 24 articles; and an "acceptance phase" (2008-2014), when institutional theory became widely used by entrepreneurship scholars, with a total of 152 articles using this perspective published in selected high impact journals.

Several literature reviews on international entrepreneurship, conducted during the last decade, have contributed to the understanding of the role of institutions. These literature reviews sometimes cover the whole field, while others are more specific. For example, Covin and Miller's (2014) review on international entrepreneurial orientation confirms that social and cultural values together with social, economic and political institutions encourage entrepreneurial orientation. Institutional voids, on the other side, reduce dramatically the potential impact of entrepreneurial orientation. Another focused review (Yang \& Gabrielsson, 2018) examines the interface between international entrepreneurship and international marketing, identifying two studies that use institutional theory.

Examining the entire field of international entrepreneurship, Jones, Coviello and Tang (2011) develop a thematic map of the literature. Institutional theory appears three times in this map. The theory has been used in the context of firm internationalization, when examining the environmental influences in this process, both in single country studies and in comparative international entrepreneurship research. In addition, the theory has been used to understand international entrepreneurship at a macro level. The authors mention that few studies have examined how the institutional environment shapes social networks. In their introduction to a special issue, Coviello, McDougall and Oviatt (2011) indicate that several studies had already integrated institutional theory into entrepreneurship research, and that this seems to be a growing trend in the field. In addition, they identify the use of institutional theory in comparative international entrepreneurship studies and recommend the use of this theoretical 
perspective in several topics, including international entrepreneurial orientation and opportunity recognition. Another review (Peiris, Akoorie, Sinha, 2012) identifies a small number of studies using institutional theory but also considers that the impact of the institutional environment is crucial to the internationalizing firm.

Kiss, Danis and Cavusgil (2012) find a growing use of institutional theory in the study of international entrepreneurship in emerging countries. Entrepreneurs from these countries find more institutional, political, and cultural barriers than their counterparts in developed countries. Differences in cultural values and norms impact entrepreneurial phenomena such as opportunity recognition, or new venture growth. In addition, the institutional context may also affect mode, strategy, and extent of internationalization. Institutional factors in economies in later stages of transition are similar to those in advanced economies. They also call the attention to specific problems in emerging economies, such as corruption, as an impediment to internationalization.

Addressing the topic of comparative international entrepreneurship, Terjesen, Hessels and Li (2016) provide a broad review of 259 empirical studies published between 1989 and 2010. These authors contend that this literature "is very fragmented, and there are substantial knowledge gaps in content, theory and methodology", and point out specifically at the "atheoretical nature" (p.299) of large part of these studies. In fact, despite being the most often used theoretical perspective in the studies examined, only 24 out of the 259 studies adopted institutional theory. Most of these articles followed the institutional economics approach, with North being the most frequently cited author, and researchers addressing national constraints to entrepreneurial activity. Some research also addressed Scott's three institutional pillars to examine differences among countries.

Summarizing, while scholars in the field of entrepreneurship and international entrepreneurship recognize the growing importance of institutional theory in both areas of study, existing reviews have mostly pointed out the fragmentary nature of international entrepreneurship research using institutional theory. An exception is a review by Szyliowicz and Galvin (2010), which offers a 
detailed evaluation of how institutional theory has been used in international entrepreneurship articles from 1992 to 2008. The review includes a total of 40 papers. The authors argue that researchers have relied too much on Scott's three pillars and point out to major flaws in the literature - oversimplification, limited understanding of Scott's model and of the interdependencies among the pillars, and very limited use of different strands of institutionalism. They also point out that "international entrepreneurship has heretofore focused on the entrepreneurship dimension to the neglect of the international" (p.324).

\section{4 \\ Method}

The present review uses articles in the fields of business, management, and entrepreneurship in peer-reviewed journals of the Scopus database (Elsevier), published between 2008 and September 2020. This time frame was based on $\mathrm{Su}$, Zhai and Karlsson's (2017) review of institutional theory in entrepreneurship research. These authors have indicated that institutional theory only became fully accepted in entrepreneurship research after 2008. In addition, Szyliowicz and Galvin's (2010) review of institutional theory in international entrepreneurship covers articles published until 2008, already providing a general picture of early research on this topic. The decision to include the fields of business, management, and entrepreneurship was taken because international entrepreneurship articles have appeared in journals related to these fields. All journals with an impact factors above 1 according to JCR in their respective areas were selected. Besides, two entrepreneurship journals were included, although not reaching the minimum impact factor, because they were deemed relevant to the area of international entrepreneurship: the Journal of International Entrepreneurship and the Journal of Small Business and Enterprise Development.

The filters used (Table 1) aimed at guaranteeing the inclusion of all the relevant articles on international entrepreneurship using institutional theory published during the 13-year period. We included both conceptual and empirical papers, assuming that even if some theoretical contributions were not tested 
empirically, they nonetheless deserved to be included to assure an adequate coverage of the theme. A total of 188 articles were initially selected from 35 journals.

Table 1. Research parameters

\begin{tabular}{|l|l|}
\hline Criteria & Values \\
\hline Keywords & $\begin{array}{l}\text { (institutions*) AND "start-up" OR "startup" OR "new venture" } \\
\text { OR "entrepreneur* AND (international*) }\end{array}$ \\
\hline Type of Document & Articles in English \\
\hline
\end{tabular}

Three criteria were adopted for the final selection of papers to be included in the analysis. First, the article should study small entrepreneurial firms, small or medium-sized firms (SMEs), new ventures or start-ups. Second, the article had to use institutional theory explicitly (by naming this theoretical perspective) or implicitly (using terms such as institutionalization, institutional change, institutional dimension, or similar). This procedure was adopted because the term "institution", used as a filter, is not always associated with institutional theory. For example, several articles on universities and innovation or university and entrepreneurial education that consider universities as institutions are not related to institutional theory. Third, the article had to deal with the internationalization of firms or to compare firms from different countries (typical of the comparative institutionalism strand). Some papers used the term "international", but in a different context. To assure that each article fitted the three research criteria the researcher and a research assistant (another PhD student) first examined all the abstracts to determine whether each paper should (or not) be included in the analysis. After this first selection, the remaining papers were read to confirm their adherence to the criteria.

As a result, 66 articles remained from the original list. The articles were then coded independently by two coders and classified in the following categories: type of article (conceptual/empirical; quantitative/qualitative); type of study (cross-country/single country/neither); country focus (home country/host county; developed/developing); and type of institution (formal/informal). 
Although a few divergences occurred between the coders, they were discussed until reaching an agreement.

The analysis proceeded in two steps. First, a descriptive analysis was performed, using the material coded and the articles, to characterize their nature in terms of whether they were conceptual or empirical and the methodology used (qualitative or quantitative). In addition, some other characteristics of the studies were examined. Second, the bibliographic coupling (BC) technique (Kessler, 1963) was employed to identify theoretical trends in the field. This technique groups the articles into research themes based on their similarity (Dagnino et al., 2015). The association is identified by the frequency of references cited for each pair of articles in the sample. The more similar the quotes between two articles, the more intense the association between them and the more likely it is that they belong to the same thematic group (Kessler, 1963). The 13-year period was divided into three sub-periods of four years, with the purpose of recognizing the theoretical trends in the field in each of the three sub-periods (the last one also included the first nine months of 2020). The use of the BC technique allowed to determine how the research themes have changed over time. The VOS Viewer software was used to conduct the analysis.

Out of the 66 articles initially selected, an analysis of the frequency of common quotes - using the criterium of at least five citations per article - led to the selection of 19 articles for the first sub-period (2008-2011), 19 articles for the second sub-period (2012-2015) and 27 articles for the third sub-period (20162020). One article was excluded from the analysis because it did not reach the five-citations criterium, thus reducing to 65 the number of articles examined in this step. A list of the most cited articles was made for each sub-period. The data was then plotted in squared matrices, with all articles displayed in the lines and in the rows, and each cell containing the number of common references between each pair of articles. The main diagonal of the matrix was filled with the number of quotes cited by the article represented by that position. The VOS Viewer software was used to draw the clusters. The assumption is that articles with more quotes in common have a higher probability to address similar themes. The 
content of the articles in each one of the clusters was analyzed qualitatively, aiming at identifying a common theme.

\section{5}

\section{Descriptive Results}

The study examines a total of 66 articles published in 23 journals (Table 2). The three journals with more articles were the Journal of International Entrepreneurship, International Business Review and the Journal of International Business Studies. The first is a journal that focuses specifically on international entrepreneurship; the second and the third are among the highest ranked journals in IB.

Table 2. Journals by number of articles published

\begin{tabular}{|l|c|}
\hline \multicolumn{1}{|c|}{ Journal } & No. of articles \\
\hline Journal of International Entrepreneurship & 10 \\
\hline International Business Review & 9 \\
\hline Journal of International Business Studies & 9 \\
\hline Journal of Small Business Management & 7 \\
\hline Asia Pacific Journal of Management & 5 \\
\hline Small Business Economics & 3 \\
\hline Corporate Governance & 2 \\
\hline European Management Journal & 2 \\
\hline International Entrepreneurship and Management Journal & 2 \\
\hline Journal of International Management & 2 \\
\hline Journal of Technology Transfer & 2 \\
\hline Management and Organization Review & 2 \\
\hline Journal of Management Studies & 1 \\
\hline Baltic Journal of Management & 1 \\
\hline California Management Review & 1 \\
\hline Corporate Social Responsibility and Environmental Management & 1 \\
\hline European Journal of International Management & 1 \\
\hline European Management Review & 1 \\
\hline International Entrepreneurship and Management Journal & 1 \\
\hline International Journal of Emerging Markets & 1 \\
\hline Journal of Small Business and Enterprise Development & 1 \\
\hline
\end{tabular}




\begin{tabular}{|l|c|}
\hline Research Policy & 1 \\
\hline International Small Business Journal & 1 \\
\hline Total & 66 \\
\hline
\end{tabular}

The literature that examines international entrepreneurship using the lenses of institutional theory is predominantly empirical and quantitative. Of the 66 articles, $56(85 \%)$ were empirical and 10 articles (15\%) conceptual. Among the empirical articles, 40 were quantitative and 16 qualitative (Table 3 ).

Table 3. Types of Articles

\begin{tabular}{|l|r|r|}
\hline Type & No. & $\%$ \\
\hline Conceptual & 10 & 15 \\
\hline Empirical & 56 & 85 \\
\hline - Quantitative & 40 & 61 \\
\hline - Qualitative & 16 & 24 \\
\hline Total & 66 & 100 \\
\hline
\end{tabular}

Among the articles employing quantitative approaches, the vast majority (29) used secondary data, 10 used survey, and one used both approaches. Interestingly, 21 articles used GEM1 data, often combined with other secondary data. As to the qualitative studies, 14 out of the 16 studies used the case method of investigation, but with a variety of units of analysis (individual entrepreneur, firm, incubator, cluster, and country). There are more cross-country (37) than singlecountry studies (19). The latter examine a restricted number of emerging or transition economies: China (5 studies), Russia (2 studies), Brazil, Colombia, Romania, Hungary, Moldova, Nepal, Ghana and Oman, in addition to a developed country, the Netherlands. The preference to performing single country studies -

${ }^{1}$ Global Entrepreneurship Monitor (GEM) is a project started by Babson College (U.S.) and London Business School (UK) to collect data about entrepreneurship in different countries. The GEM project's methodology provides indicators from individuals involved in different stages of entrepreneurship dynamics, including start-up efforts, nascent entrepreneurs, new ventures, and established firms. The project has built a rich database of entrepreneurial activities in up to 115 countries. 
which often allow a more in-depth investigation - in developing or transitional countries may be a result of the limited knowledge of Western scholars about these countries. The overwhelming majority of the articles examines home country issues; only four studies adopt the host country perspective, and three of them also examine home country issues (Table 4). This situation stems from the high emphasis on country studies, which tend to portray different national (home country) systems. Fewer articles examined developed countries only; most articles looked at developing countries only or both types of countries. Finally, almost half of the articles examine both formal and informal institutions.

Table 4. Characteristics of the studies reviewed

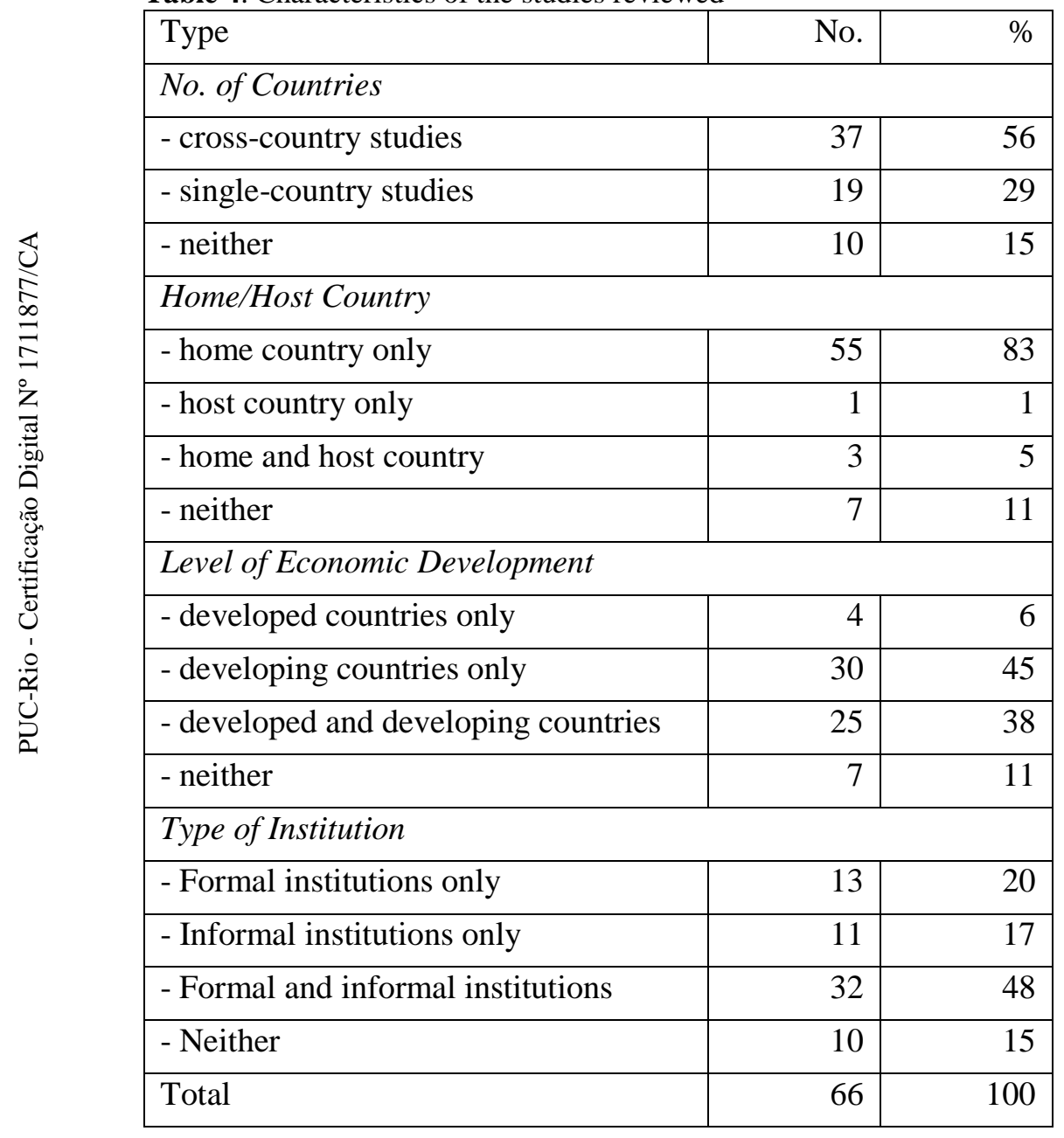

A list of the most often cited articles (20 or more citations) in each subperiod appears in Table 5. The most cited articles in each sub-period are usually the leaders of each theme found in the different clusters. In the sub-period 1 
(2008-2011) the most cited article is the one by Welter and Smallbone (2011), which analyses entrepreneurial behavior in emerging and transition economies. The second and third most cited articles in this sub-period (Bowen \& De Clercq, 2008; Stephan \& Uhlaner, 2010) are both studies on comparative entrepreneurship, using GEM data. In the second sub-period (2012-2015), the most often referenced paper is Stephan, Uhlaner and Stride (2015), also a crosscountry study, using GEM data. The paper examines how the institutional factors at the country level influence social entrepreneurship. The second paper, by Urbano and Alvarez (2014), also makes use of GEM data to examine the influence of the three pillars on the probability of becoming an entrepreneur. The third paper most often cited in the second period (Tang \& Tang, 2012) investigates in a cross-cultural setting the influence of Scott's three pillars on the probability of becoming an entrepreneur.

Finally, in the third sub-period (2016-2020), Zhang and White's (2016) article uses a qualitative research approach, based on a longitudinal case study of the solar photovoltaic industry in China, focusing on the differences between early and late entrants and different barriers encountered by these firms. The second paper is conceptual (Audretsch \& Caiazza, 2016), and looks at issues of competitiveness and performance. The third most cited paper in this sub-period (Hoogendoorn, 2016) is similar to others in the previous sub-periods; it is a crosscountry study using GEM data. The paper examines the role of institutional factors on the proportion of social start-ups on the total number of start-ups.

Table 5. Most often cited articles

\begin{tabular}{|l|c|}
\hline \multicolumn{1}{|c|}{ Sub-period 1 (2008-2011) } & No. of Citations \\
\hline Welter, F. \& Smallbone, D. (2011) & 330 \\
\hline Bowen, H. P., \& De Clercq, D. (2008) & 306 \\
\hline Stephan, U., \& Uhlaner, L. M. (2010) & 247 \\
\hline Lu, Y., Zhou, L., Bruton, G., \& Li, W. (2010) & 223 \\
\hline Levie, J., \& Autio, E. (2011) & 155 \\
\hline Bruton, G. D., Ahlstrom, D., \& Puky, T. (2009) & 123 \\
\hline Riddle, L., Hrivnak, G. A., \& Nielsen, T. M. (2010) & 109 \\
\hline De Clercq, D., Danis, W. M., \& Dakhli, M. (2010) & 100 \\
\hline Riddle, L., \& Brinkerhoff, J. (2011) & 88 \\
\hline
\end{tabular}




\begin{tabular}{|c|c|}
\hline Danis, W. M., Chiaburu, D. S., \& Lyles, M. A. (2010) & 82 \\
\hline Kiss, A. N., \& Danis, W. M. (2008) & 78 \\
\hline Dodgson, M. (2009) & 60 \\
\hline Szyliowicz, D., \& Galvin, T. (2010) & 59 \\
\hline Walder, A. G. (2011) & 54 \\
\hline Kiss, A. N., \& Danis, W. M. (2010) & 40 \\
\hline Dennis Jr, W. J. (2011) & 36 \\
\hline Zettinig, P., \& Benson-Rea, M. (2008) & 27 \\
\hline Terjesen, S., \& Hessels, J. (2009) & 24 \\
\hline Sub-period $2(2012-2015)$ & \\
\hline Stephan, U., Uhlaner, L. M., \& Stride, C. (2015) & 186 \\
\hline Urbano, D., \& Alvarez, C. (2014) & 112 \\
\hline Tang, Z., \& Tang, J. (2012) & 72 \\
\hline Oparaocha, G. O. (2015) & 64 \\
\hline Cumming, D., Johan, S., \& Zhang, M. (2014) & 53 \\
\hline Shirokova, G., \& McDougall-Covin, P. (2012) & 49 \\
\hline Yousafzai, S. Y., Saeed, S., \& Muffatto, M. (2015) & 47 \\
\hline Engel, J. S. (2015) & 44 \\
\hline Volchek, D., Jantunen, A., \& Saarenketo, S. (2013) & 28 \\
\hline Lin, D., Lu, J., Li, P. P., \& Liu, X. (2015) & 26 \\
\hline Sigmund, S., Semrau, T., \& Wegner, D. (2015) & 23 \\
\hline Hafer, R. W., \& Jones, G. (2015) & 22 \\
\hline Sub-period 3 (2016-2020) & \\
\hline Zhang, W., \& White, S. (2016) & 47 \\
\hline Audretsch, D., \& Caiazza, R. (2016) & 41 \\
\hline Hoogendoorn, B. (2016) & 39 \\
\hline Ayuso, S., \& Navarrete-Báez, F. E. (2018) & 33 \\
\hline Muralidharan, E., \& Pathak, S. (2017) & 29 \\
\hline Lim, D. S., Oh, C. H., \& De Clercq, D. (2016) & 29 \\
\hline Nikolaev, B. N., Boudreaux, C. J., \& Palich, L. (2018) & 26 \\
\hline Tomizawa, A., Zhao, L., Bassellier, G., \& Ahlstrom, D. (2020) & 26 \\
\hline Deng, Z., \& Sinkovics, R. R. (2018) & 26 \\
\hline Young, S. L., Welter, C., \& Conger, M. (2018) & 23 \\
\hline
\end{tabular}

\subsection{Bibliographic Coupling (BC)}


The BC analysis covered three sub-periods: 2008-2011, 2012-2015 e 2016-2020.

\section{$\underline{\text { Sub-Period } 1 \text { - 2008-2011 }}$}

The 19 articles selected to analyze the first sub-period, between 2008 and 2011, formed three thematic clusters. Figure 1 presents the articles in a twodimensional space. The clusters include articles with similar themes and more citations in common.

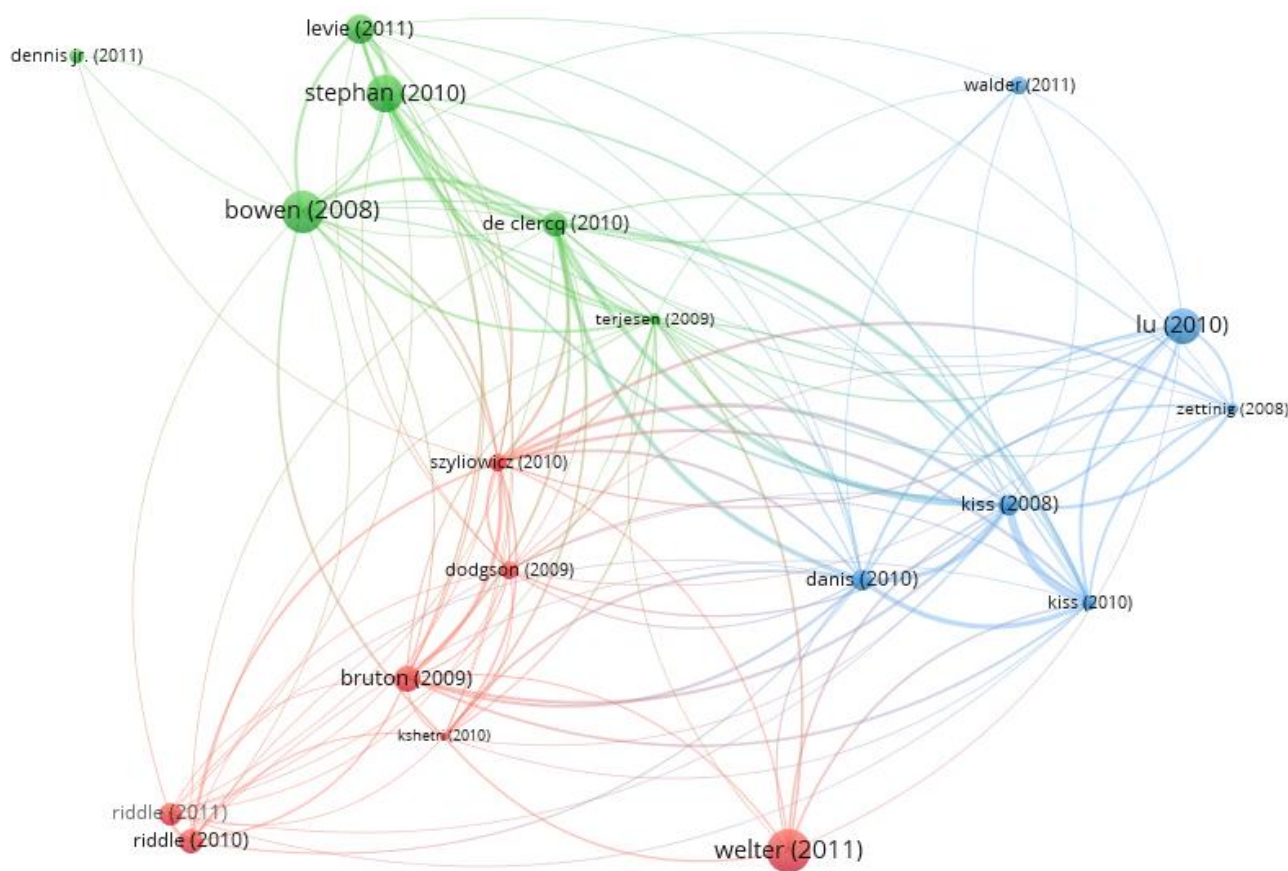

Figure 1 - Thematic clusters for the sub-period 2008-2011

Cluster 1, named Comparative Entrepreneurship, includes six papers, all of them adopting a macro, cross-country approach. These articles are directly associated to one of the strands of institutional theory, named comparative institutionalism. The tendency in this literature to focus on the country level, instead of the firm-level, is probably due to the fact that institutional theory gives less attention to the individual firm, as pointed out earlier by Szyliowicz and Galvin (2010). Five papers are quantitative, and use the GEM database, often combined with data from other sources, such as, for example, the Globe Project (Stephen \& Uhlaner, 2010), the Global Competitiveness Report (Terjesen \& Hessels, 2009), or the World Values Survey (De Clercq, Danis \& Dakhli, 2010). 
Only one paper is conceptual (Dennis, 2011) and offers typologies of institutional environments to be used as a basis for public policy. All the empirical papers examine formal institutions, while two also consider informal ones. Although all the papers in this cluster use institutional theory as a theoretical background and utilize concepts from this theory, not all of them mention institutional theory explicitly. Among the theoretical perspectives named appear varieties of capitalism, national business systems, national innovation systems, and several others. The papers also do not refer explicitly to one of the several strands of institutionalism, but it is sometimes possible to detect the strand by examining the references utilized, or by the arguments set forth by the authors. Even if most of these papers could be classified under the comparative institutionalism label, only one (Bowen \& De Clercq, 2008) does perfectly fit the label. The papers tend to use more authors from the institutional economics stream, but often they also cite authors that are key references of organizational institutionalism.

Cluster 2 - Institutional Change- includes seven papers that have in common the study of institutional change in emerging and transition economies. This cluster includes a variety of conceptual and empirical papers, using a micro or a macro approach. There are cross-country and single country studies. Four out of the five empirical papers are qualitative, using case studies: Bruton, Ahlstrom and Puky (2009) research with venture capital firms in Latin America and Asia, examining differences posed by the institutional environment in which these firms operate; Riddle, Hrivnak and Nielsen (2010) and Riddle and Brinkerhoff's (2011) case studies of organizations operating in diaspora contexts; and Dodgson (2009) country studies of innovation systems. The quantitative paper uses secondary data from the World Business Environment Survey (Kshetri, 2010). Interestingly, more papers in this cluster than in the previous one mention explicitly institutional theory as their theoretical perspective.

Finally, Cluster 3 -Networks and Internationalization - includes six papers that study the role of social ties or networks in promoting internationalization. One major difference concerning the other clusters in this sub-period is the focus on internationalization of entrepreneurial firms, rather than on comparing characteristics of the institutional environment for entrepreneurship in different 
countries. Three of the six papers in this cluster are conceptual and three are empirical (one case study and two survey-based research). The empirical papers analyze China (Lu et al., 2010; Walder, 2011) and Hungary (Danis, Chiaburu \& Lyles, 2010). The six papers support the argument that social ties play a role in the successful adaptation of firms to new institutional environments. For example, Lu et al. (2010) study firm-specific capabilities, including managerial ties, that allow the firm to transform key resources into performance outcomes; Kiss and Danis $(2008,2010)$ examine the role of social networks in the internationalization process of new ventures; and Danis, Chiaburu and Lyles (2010) find a strong and significant relationship between managerial networking intensity and firm growth in an early phase of an institutional transition process. Finally, a conceptual paper (Zettinig \& Benson-Rea, 2008), although focusing mostly on international entrepreneurship issues, is concerned with problems related to INVs' legitimacy and their adaptation to multiple institutional environments. Despite using some key concepts of institutional theory, the paper does not explicitly use this theoretical perspective. The same problem has been reported by other authors that reviewed the IB and IE literature using institutional theory (e.g., Terjesen, Hessels \& Li, 2016).

\section{Sub-Period 2 - 2012-2015}

In the second sub-period, from 2012 to 2015, 19 articles formed five clusters (Figure 2). 


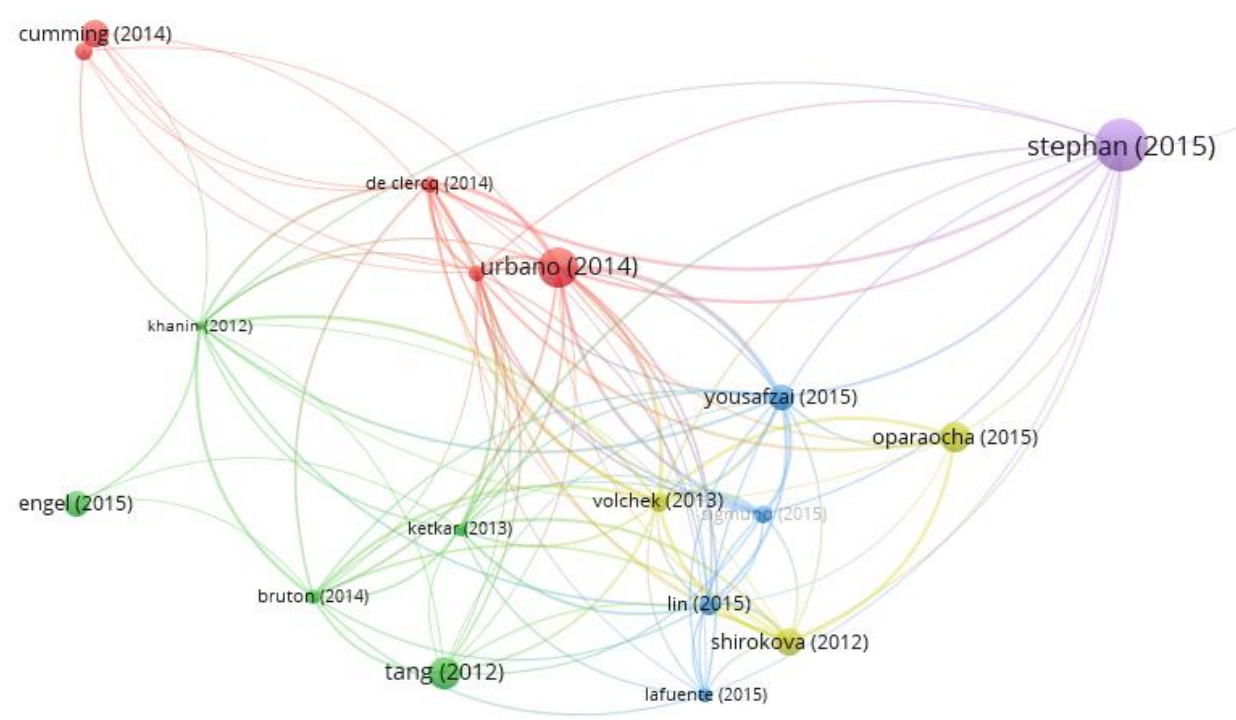

Figure 2 - BC of the sub-period 2012-2015 (five clusters)

The first cluster, named Comparative Entrepreneurship, consists of five cross-country studies that address the relationship between start-ups or new ventures and variables of the institutional environment. For example, Chowdhury, Audretsch and Belitski (2015) look at the impact of corruption on nascent entrepreneurship and find that corruption can play a dual role - "grease" and "sand" - on the development of start-ups; De Clercq, Lim and Oh (2014) find that informal investments (personal funds from relatives or friends) influence new venture activity, particularly in developing countries; Hafer and Jones (2015) examine the relationship between the country's cognitive skills and high-quality entrepreneurship; and Urbano and Alvarez (2014) indicate that Scott's three pillars influence the probability of becoming an entrepreneur, with the culturalcognitive dimension showing stronger empirical support. All articles on Cluster 1 are empirical and quantitative, using secondary data from the GEM database and other sources. Four articles explicitly mention institutional theory or one of its strands as one of the theoretical perspectives adopted in the study, but one article, although using constructs of institutional theory, does not mention it explicitly.

The second cluster - Institutions and Entrepreneurial Behavior - groups five articles that examine firms' responses to institutional variables. Examples of papers in this cluster are Bruton, Lau and Obloj's (2014) study, comparing strategic orientations, strategies adopted and "top management dynamics" in three 
transition economies with different institutional contexts; Ketkar and Acs's (2013) analysis of the impact of cultural variables on the adoption of internationalization; and Tang and Tang's (2015) test of whether different strategic types influence the relationship between entrepreneurial orientation and performance. One paper examines the internationalization of venture capital firms (Khanin, Ogilvie \& Leibsohn, 2012). All the papers are empirical; three use secondary data, one is survey-based, and one consists of case studies of clusters of innovation in different countries (Engel, 2015). Four articles adopt explicitly institutional theory, and one does not mention it, but uses institutional theory constructs.

The third cluster - Institutions and Firm Resources and Capabilities contains four papers that address firm's resources and capabilities. These papers adopt a macro or micro approach and are based on a variety of methods (survey, secondary data, and case studies). Lafuente, Stoian and Rialp (2015) look at to what extent resources and capabilities, together with institutional variables, explain the SME decision to internationalize in the context of a transitional economy. Social relationships and network capabilities are examined by Lin et al. (2015) and Sigmund, Semrau and Wegner (2015), while Yousafzai, Saeed and Muffatto (2015) look at the mediating role of national representations of female entrepreneurs and their impact on the relationship between the regulatory, normative and cognitive pillars of the institutional environment and women's entrepreneurial leadership.

The fourth cluster - Networks and Internationalization - contains three papers, two of which address the use of networks in the internationalization of SMEs. Oparaocha (2015) analyzes the "awareness, access to, and actual use of the resources available through institutional networks and whether these are inducements or deterrents for entrepreneurial activities in foreign markets" (p.861), based on five case studies of firms from two Scandinavian countries. On a different note, Shirokova and McDougall-Covin (2012) did not find networks to be as important with Russian entrepreneurs as predicted by the literature or evidenced in other studies. Both papers refer explicitly to institutional theory. Finally, the third paper in this cluster (Volchek, Jantunen \& Saarenketo, 2013) examines the influence of Scott's three pillars on the propensity of an SME to 
internationalize and to innovate, and finds, consistent with other studies, a stronger influence of the cognitive pillar.

Finally, the fifth cluster, named Institutional Change, comprises two crosscountry studies that examine the role of institutions on entrepreneurship and social entrepreneurship. They focus on institutional variables and on subareas within institutional theory; Stephan, Uhlaner and Stride (2015, p.308) indicate they use "institutional void and institutional support perspectives" and Gevorkyan (2015, p. 1019) mentions that the study contributes to "institutional studies on transitional economies."

$\underline{\text { Sub-Period } 3 \text { - 2016-2020 }}$

As to the last sub-period, from 2016 to 2020 (September), 27 articles formed four clusters (Figure 3).

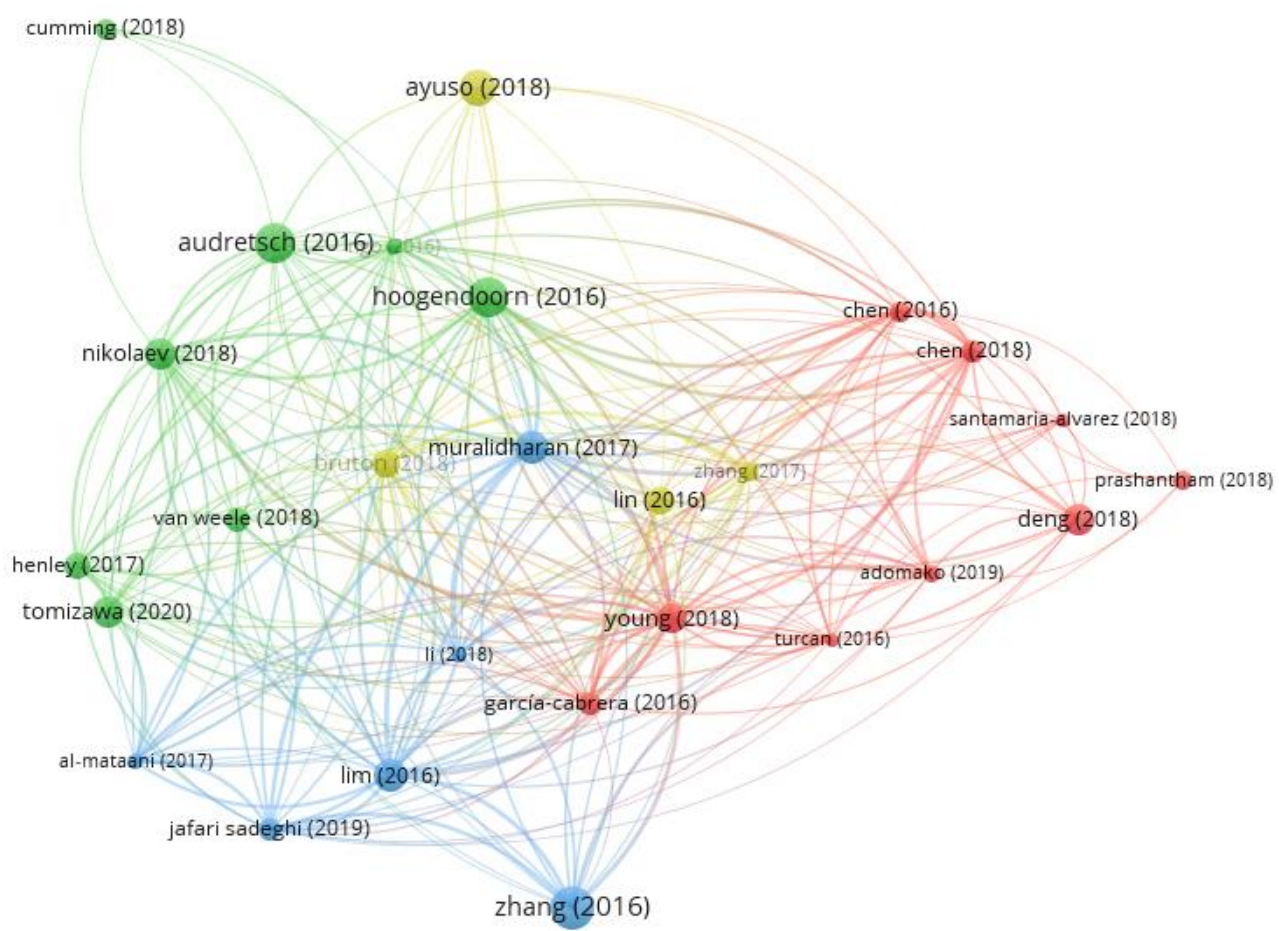

Figure 3 - BC of the sub-period 2016-2020 
Cluster 1 - Institutional Enablers of Internationalization - comprises nine articles that address different facets of venture internationalization. Eight papers are empirical and one conceptual. Methods include survey, secondary data analysis, case studies and ethnography. The three cross-country studies use the GEM database and/or other sources of country data. The single-country papers have their locus of research in emerging economies (Brazil, China, Colombia, Ghana, and Moldova). Two studies find that institutional voids in emerging countries can also play a positive role in venture internationalization (Adomako et al., 2019; Chen, Saarenketo \& Puumalainen, 2016). Home country formal institutions have a supportive role in the internationalization of for-profit new ventures (Chen, Saarenketo and Puumalainen, 2018), but the entrepreneur's perception of the regulative, normative, and cognitive dimensions of the institutional environment also interferes in the decision (García-Cabrera, GarcíaSoto \& Durán-Herrera, 2016). Deng and Sinkovics (2018) examine the relationship between institutional distance and the rapid expansion of international new ventures in China. The role of networks in transnational entrepreneurship is revisited by Santamaria-Alvarez et al. (2018). Six papers explicitly use institutional theory (or institution-based view, or neoinstitutionalism) as a theoretical perspective, Three papers use institutional theory as a conceptual background, referring to constructs and citing references associated to this theory, but without mentioning it explicitly.

Cluster 2 - Institutions and Entrepreneurial Behavior - consists of eight papers, three of which are conceptual and five empirical. Two conceptual papers propose theoretical frameworks to evaluate the impact of institutional factors on different aspects. Audretsch and Caiazza's (2016) proposal aims at explaining the competitiveness of firms, as well as the performance of places, while Ngo, Janssen and Falize's (2016) model looks at how to promote the internationalization of smaller firms from emerging and transition economies. The third paper (Tomizawa et al., 2020) adopts a historical perspective to understand the interrelationships of institutions, international trade and economic growth, and their supportive role to entrepreneurship and innovation. Among the empirical 
work, four studies are based on secondary data (three use GEM and other databases; one uses the VentureXpert database) and one uses interviews. The five empirical papers examine the relationship between institutions, formal or informal, and entrepreneurial behavior. Henley (2017) finds an association between evangelical and Pentecostal affiliation and entrepreneurial behavior, as well as a mediating effect of pluralism and regulation. Cumming and Schwienbacher (2018) examine the institutional environments of the countries to which fintech venture capital have gone in recent years, identifying their presence in countries with low quality regulatory environment. Nikolaev, Boudreaux and Palich (2018) identify relationships between certain institutions and the occurrence of opportunity-driven entrepreneurship and necessity-driven entrepreneurship. Hoogendoorn (2016) finds that the regulatory quality and public expenditure increase the share of social start-ups in all start-ups. Finally, Van Weele et al. (2018) examine comparative incubation practices in several countries and their impact on entrepreneurial ecosystems. As to their use of institutional theory, all papers used concepts and cite this literature, but two papers do not indicate institutional theory as a theoretical perspective adopted in the study.

Cluster 3 - Individual-level Factors and Institutional Conditions includes six papers that explore in different ways the complex interaction between entrepreneur characteristics and institutional conditions. The papers in this cluster are empirical, adopting both quantitative (secondary data) and qualitative strategies (interviews, case studies). The four quantitative studies use secondary data (GEM, GlOBE, World Values Survey and others). These studies adopt a comparative approach to entrepreneurship, either comparing the role of institutions to foster entrepreneurship or to encourage firm internationalization. Two papers look specifically at human capital's role in promoting entrepreneurship or firm internationalization (Jafari-Sadeghi et al., 2020; Lim, Oh \& De Clercq, 2016). Two papers use Scott's three pillars framework (Li, 2018; Lim, Oh \& De Clercq, 2016). Muralidharan and Pathak (2017) look specifically at the influence of certain informal institutions (performance orientation, selfexpression, and social desirability of entrepreneurship) on the inclination of newly founded firms to internationalize. Using in-depth interviews, Al-Mataani, 
Wainwright and Demirel (2017) also approach informal institutions, but they explore a very specific issue, which is the role of "hidden" international entrepreneurs in a developing economy, and how they contribute to institutional change. Zhang and White (2016) adopt a longitudinal approach based on case studies to examine differences between early and late entrants in a new industry in China, and how late entrants benefitted from efforts to establish legitimacy by early entrants, in such a way that the Chinese industry became the leading global manufacturer. Their study sheds light on how the industry and the institutional environment co-evolve. Institutional theory, or a perspective within institutional theory, is explicitly mentioned by all the papers in this cluster.

Cluster 4, named Institutions and Entrepreneurial Outcomes, consists of four papers that measure the relationship between institutions and different outcomes of entrepreneurial decisions: new venture performance (Bruton, $\mathrm{Su}$ and Filatotchev, 2018); commitment to sustainable development (Ayuso and Navarrete-Báez, 2018); international performance of export ventures (Zhang, Gao and Cho, 2017); and returnees' entrepreneurial decisions (Lin et al., 2016). The four studies are empirical, based on survey data and adopt institutional theory as a theoretical perspective.

A summary of the thematic clusters identified in the 13 years of the present review appears in Table 6.

Table 6. Summary of Clusters

\begin{tabular}{|c|c|c|}
\hline 2008-2011 & $2012-2015$ & 020 \\
\hline 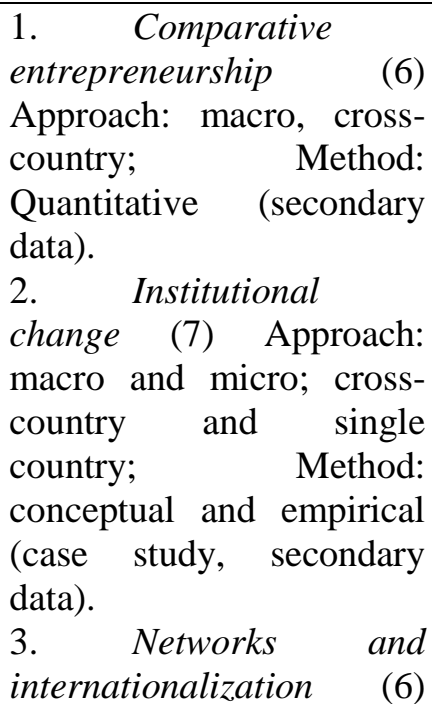 & 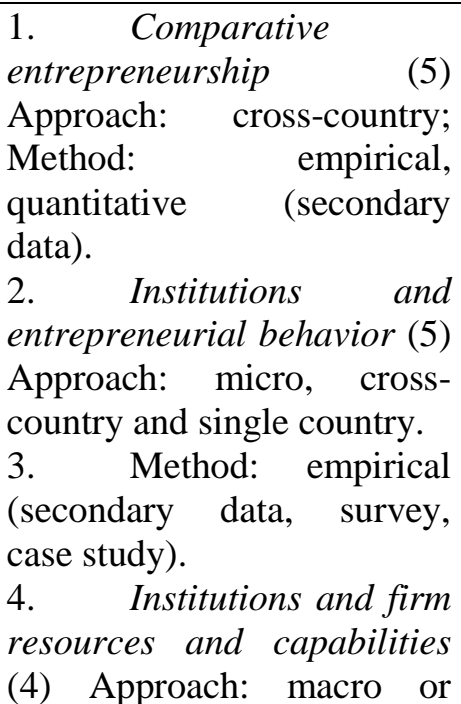 & $\begin{array}{l}\text { 1. Institutional } \\
\text { enablers of } \\
\text { internationalization (9) } \\
\text { Approach:. Macro and } \\
\text { micro, cross-country and } \\
\text { single country. Method: } \\
\text { conceptual and empirical } \\
\text { (survey, secondary data, } \\
\text { case study, ethnography). } \\
\text { 2. Institutions and } \\
\text { entrepreneurial behavior (8) } \\
\text { Approach: macro, cross- } \\
\text { country. Method: conceptual } \\
\text { and empirical (secondary } \\
\text { data, interviews). } \\
\text { 3. Individual-level }\end{array}$ \\
\hline
\end{tabular}




\begin{tabular}{|c|c|c|}
\hline $\begin{array}{l}\text { Approach: micro, single } \\
\text { country. } \\
\text { conceptual and empirical } \\
\text { (survey, case study). }\end{array}$ & $\begin{array}{l}\text { micro, single and cross- } \\
\text { country; Method: empirical } \\
\text { (survey, secondary data, } \\
\text { case studies). } \\
\text { 5. Networks and } \\
\text { internationalization (3) } \\
\text { Approach: micro, cross- } \\
\text { country and single country; } \\
\text { Method: empirical (case } \\
\text { study, secondary data). } \\
\text { 6. Institutional change } \\
\text { (2) Approach: cross-country; } \\
\text { Method: empirical. }\end{array}$ & $\begin{array}{l}\text { factors and institutional } \\
\text { conditions (6) Approach: } \\
\text { macro and micro, cross- } \\
\text { country and single country; } \\
\text { Method: empirical } \\
\text { (secondary data, interviews, } \\
\text { case studies). } \\
4 . \quad \text { Institutions and } \\
\text { entrepreneurial outcomes } \\
\text { (4) - Approach: micro; } \\
\text { Method: empirical (survey). }\end{array}$ \\
\hline
\end{tabular}

\section{7 \\ Discussion}

The review of the recent literature on international entrepreneurship and institutional theory shows a large number of empirical and quantitative studies, particularly using a cross-country approach. Cross-country studies adopt the home country perspective, that is, the country where the entrepreneur or the entrepreneurial firm is established. A large part of these articles uses secondary data. There is a need, however, to the use of other research methods, in order to improve the present knowledge on the complex relationship between international entrepreneurship and the institutional environment. For example, there is a limited number of articles using surveys, which of course are more difficult to be applied in a cross-country design and are also much more costly. Nevertheless, data gathered from surveys may fit better several research questions than secondary data. There is also substantial room for research using qualitative methods, such as case studies, ethnographic studies, narratives, and others.

The content of the articles has remained, to a large extent, quite similar along the whole period. Two major types of studies appear: comparative (crosscountry) entrepreneurship studies and firm internationalization studies. Comparative studies are typically associated to the comparative institutionalism strand in institutional theory. The proliferation of this type of studies is mostly due to the availability of large databases, particularly the GEM database, easily available to scholars, which has undoubtfully contributed to the development of a 
comparative entrepreneurship stream within the field of international entrepreneurship. However, the literature examined is strongly biased towards comparative institutionalism. Thus, there is still a broad space for research that contributes to the understanding of the internationalization of entrepreneurial firms.

Although comparative studies represent a large part of the sample, internationalization studies have become more frequent from the first to the third sub-period. Network studies appeared mostly in the first period, but also in the second, focusing on how social ties supported the internationalization of entrepreneurial firms. Yet in the second period two new clusters emerged, one examining the strategic behavior of entrepreneurial firms when facing institutional challenges in their internationalization, and the other focusing on firm's resources and capabilities to internationalize. Finally, the third period shows more diversity in themes concerning internationalization, including the outcomes of internationalization. In general, there is a tendency that the articles in each subsequent sub-period to focus on more specific issues, and to adopt "a more finegrained angle" (Bruton, Lau \& Obloj, 2014, p. 697) to examine institutional issues related to international entrepreneurship.

Many articles across the three sub-periods do not explicitly indicate the use of institutional theory as a theoretical perspective adopted in the study. In fact, some papers adopt it implicitly as a grand theory, under which more limited-range theories are used. Other papers remain atheoretical as pointed out by Terjesen, Hessels and Li (2016). In addition, very few papers indicate the strand of institutional theory used. One has to guess which strand of institutional theory is used based on the references in the article; even so, it often remains unclear. Most authors seem to follow the stream of institutional economics, but it is quite common the use of the literature from both institutional economics and organizational institutionalism. Interestingly, the flaws pointed out by Szyliowicz and Galvin (2010) in the international entrepreneurship literature using institutional theory from 1992 to 2008 - oversimplification, lack of understanding of the three pillars' model and the relationship among them and ignoring the 
different strands of institutionalism - appear to remain in much of the research published during the 13 years subsequent to their evaluation.

Several issues remain open for further research, particularly if researchers adopt a meso or micro approach. For example, the role of technology parks, industrial districts and clusters in firm internationalization has been examined only in a few articles (e.g., Engel, 2015), and digital clusters were not examined at all. Yet, these agglomerations may not only help entrepreneurial firms to internationalize, but also to reduce institutional distance and, in the case of emerging market firms, to overcome institutional voids. Diaspora studies focusing on firm internationalization using institutional theory are rare, but they could also be fruitful in understanding internationalization from a host country to the home country (such as the study of returnees by Lim et al., 2016). From a micro perspective, there is substantial room to develop research on the process of international opportunity creation and discovery as the entrepreneur faces new environmental conditions in a host country. Issues regarding how entrepreneurs learn from a different institutional environment and transfer knowledge to their home country could also deserve scholarly attention. In addition, there is a lack of studies focusing specifically on how mature entrepreneurial firms deal with home country and host country institutional differences.

\section{8 Final Remarks}

This review of the literature contributes not only to analyze the bulk of the literature on international entrepreneurship using an institutional perspective, but also helps to identify the main themes that emerged in the last years. The literature examined is strongly biased towards comparative institutionalism. Thus, there is still a broad space for research that contributes to the understanding of the internationalization of entrepreneurial firms. The limited number of studies that focuses on these issues tend to examine home country factors, with a small number of studies focusing on the challenges faced by entrepreneurial firms entering host countries with different institutional environments. 
This review has some limitations. The method of selection of the articles and the filters used may exclude some important works from the identified themes. The clustering method may also cause a bias in the identification of the themes as different ones could emerge from other configurations. However, these limitations did not prevent the study from providing relevant contributions.

\section{9 References}

Adomako, S., Amankwah-Amoah, J., Dankwah, G. O., Danso, A., \& Donbesuur, F. (2019). Institutional voids, international learning effort and internationalization of emerging market new ventures. Journal of International Management, 25(4), 100666.

Al-Mataani, R., Wainwright, T., \& Demirel, P. (2017). Hidden entrepreneurs: Informal practices within the formal economy. European Management Review, 14(4), 361-376.

Audretsch, D., \& Caiazza, R. (2016). Technology transfer and entrepreneurship: cross-national analysis. The Journal of Technology Transfer, 41(6), 1247-1259.

Álvarez, I.C., Barbero, J., Rodríguez-Pose,A., \& Zofío, J.L. (2018). Does institutional quality matter for trade? Institutional conditions in a sectoral trade framework. World Development, 103, 72-87.

Ayuso, S., \& Navarrete-Báez, F. E. (2018). How does entrepreneurial and international orientation influence SMEs' commitment to sustainable development? Empirical evidence from Spain and Mexico. Corporate Social Responsibility and Environmental Management, 25(1), 80-94.

Bowen, H. P., \& De Clercq, D. (2008). Institutional context and the allocation of entrepreneurial effort. Journal of International Business Studies, 39(4), 747-767.

Bruton, G. D., Ahlstrom, D., \& Li, H-L. (2010). Institutional theory and entrepreneurship: where we are now and where do we need to move in the future? Entrepreneurship Theory and Practice, 34(3), 421-440. 
Bruton, G. D., Ahlstrom, D., \& Puky, T. (2009). Institutional differences and the development of entrepreneurial ventures: A comparison of the venture capital industries in Latin America and Asia. Journal of International Business Studies, 40(5), 762-778.

Bruton, G. D., Lau, C. M., \& Obloj, K. (2014). Institutions, resources and firm strategies: a comparative analysis of entrepreneurial firms in three transitional economies. European Journal of International Management, 8(6), 697-720.

Bruton, G. D., Su, Z., \& Filatotchev, I. (2018). New venture performance in transition economies from different institutional perspectives. Journal of Small Business Management, 56(3), 374-391.

Bush, P. D. (1987). The theory of institutional change. Journal of Economic Issues, 21(3), 1075-1116.

Chen, J., Saarenketo, S., \& Puumalainen, K. (2016). Internationalization and value orientation of entrepreneurial ventures - a Latin American perspective. Journal of International Entrepreneurship, 14(1), 32-51.

Chen, J., Saarenketo, S., \& Puumalainen, K. (2018). Home country institutions, social value orientation, and the internationalization of ventures. International Business Review, 27(2), 443-454.

Cheng, H. L., \& Yu, C. M. J. (2008). Institutional pressures and initiation of internationalization: Evidence from Taiwanese small-and medium-sized enterprises. International Business Review, 17(3), 331-348.

Chowdhury, F., Audretsch, D. B., \& Belitski, M. (2015). Does corruption matter for international entrepreneurship?. International Entrepreneurship and Management Journal, 11(4), 959-980.

Coviello, N. E., McDougall, P. P., \& Oviatt, B. M. (2011). The emergence, advance and future of international entrepreneurship research-An introduction to the special forum. Journal of Business Venturing, 26(6), 625-631.

Covin, J. G., \& Miller, D. (2014). International entrepreneurial orientation: Conceptual considerations, research themes, measurement issues, and future research directions. Entrepreneurship Theory and Practice, 38(1), 11-44. 
Cumming, D., Johan, S., \& Zhang, M. (2014). The economic impact of entrepreneurship: Comparing international datasets. Corporate Governance: An International Review, 22(2), 162-178.

Cumming, D. J., \& Schwienbacher, A. (2018). Fintech venture capital. Corporate Governance: An International Review, 26(5), 374-389.

Dagnino, G. B., Levanti, G., Minà, A., \& Picone, P. M. (2015). Interorganizational network and innovation: A bibliometric study and proposed research agenda. Journal of Business \& Industrial Marketing, 30(3/4), 354-377.

Danis, W. M., Chiaburu, D. S., \& Lyles, M. A. (2010). The impact of managerial networking intensity and market-based strategies on firm growth during institutional upheaval: A study of small and medium-sized enterprises in a transition economy. Journal of International Business Studies, 41(2), 287-307.

De Clercq, D., Danis, W. M., \& Dakhli, M. (2010). The moderating effect of institutional context on the relationship between associational activity and new business activity in emerging economies. International Business Review, 19(1), 85-101.

De Clercq, D., Lim, D. S., \& Oh, C. H. (2014). Hierarchy and conservatism in the contributions of resources to entrepreneurial activity. Small Business Economics, 42(3), 507-522.

Deng, Z., \& Sinkovics, R. R. (2018). Rapid expansion of international new ventures across institutional distance. Journal of International Business Studies, 49(8), 1010-1032.

Dennis Jr, W. J. (2011). Entrepreneurship, small business and public policy levers. Journal of Small Business Management, 49(1), 92-106.

Demirbag, M., Apaydin, M., \& Tatoglu, E. (2011). Survival of Japanese subsidiaries in the Middle East and North Africa. Journal of World Business, 46(4), 411-425.

Dhanaraj, C., \& Beamish, P. (2009). Institutional environment and subsidiary survival. Management International Review, 49, 291-312.

DiMaggio, P. J., \& Powell, W. W. (1983). The iron cage revisited: Institutional isomorphism and collective rationality in organizational fields. American Sociological Review, 147-160. 
Dodgson, M. (2009). Asia's national innovation systems: Institutional adaptability and rigidity in the face of global innovation challenges. Asia Pacific Journal of Management, 26(3), 589-609.

Dunning, J. H., \& Lundan, S. M. (2008). Institutions and the OLI paradigm of the multinational enterprise. Asia Pacific Journal of Management, 25(4), 573-593.

Engel, J. S. (2015). Global clusters of innovation: Lessons from Silicon Valley. California Management Review, 57(2), 36-65.

Friel, D. (2017). Understanding institutions: different paradigms, different conclusions. Revista de Administração, 52(2), 212-214.

García-Cabrera, A. M., García-Soto, M. G., \& Durán-Herrera, J. J. (2016). Opportunity motivation and SME internationalisation in emerging countries: Evidence from entrepreneurs' perception of institutions. International Entrepreneurship and Management Journal, 12(3), 879-910.

Gevorkyan, A. V. (2015). The legends of the Caucasus: Economic transformation of Armenia and Georgia. International Business Review, 24(6), 1009-1024.

Hafer, R. W., \& Jones, G. (2015). Are entrepreneurship and cognitive skills related? Some international evidence. Small Business Economics, 44(2), 283-298.

Hair, J. F., Ringle, C. M., \& Sarstedt, M. (2013). Partial least squares structural equation modeling: Rigorous applications, better results and higher acceptance. Long Range Planning, 46(1-2), 1-12.

Henisz, W. J., \& Delios, A. (2000). Learning about the institutional environment. In: Ingram, P. \& Silverman, B. S. (Eds.) The New Institutionalism in Strategic Management (Advances in Strategic Management, Vol. 19). Bingley: Emerald (pp. 339-372).

Henisz, W. J., \& Swaminathan, A. (2008). Institutions and international business. Journal of International Business Studies, 39(4), 537-539.

Henley, A. (2017). Does religion influence entrepreneurial behaviour?. International Small Business Journal, 35(5), 597-617. 
Hoogendoorn, B. (2016). The prevalence and determinants of social entrepreneurship at the macro level. Journal of Small Business Management, 54(sup1), 278-296.

Hotho, J. J., \& Pedersen, T. (2012) Beyond the 'rules of the game': three institutional approaches and how they matter for international business. In: Wood, G. \& Demirbag, M. (eds.) Handbook of Institutional Approaches to International Business. Cheltenham, UK: Edward Elgar. (pp.236-273).

Jafari-Sadeghi, V., Nkongolo-Bakenda, J. M., Dana, L. P., Anderson, R. B., \& Biancone, P. P. (2020). Home country institutional context and entrepreneurial internationalization: The significance of human capital attributes. Journal of International Entrepreneurship, 18, 165-195.

James, B.E., Sawant, R.J., \& Bendickson, J.S. (2020). Emerging market multinationals' firm-specific advantages, institutional distance, and foreign acquisition location choice, International Business Review, 9(5), art.101702.

Jones, M. V., Coviello, N., \& Tang, Y. K. (2011). International entrepreneurship research (1989-2009): a domain ontology and thematic analysis. Journal of Business Venturing, 26(6), 632-659.

Kessler, M. M. (1965). Comparison of the results of bibliographic coupling and analytic subject indexing. American Documentation, 16(3), 223-233.

Khanin, D., Ogilvie, K., \& Leibsohn, D. (2012). International entrepreneurship, venture capital networks, and reinvestment decisions. Journal of International Entrepreneurship, 10(1), 1-24

Khanna, T., \& Palepu, K. (1997). Why focused strategies may be wrong for emerging markets. Harvard Business Review, 75(4), 41-51.

Ketkar, S., \& Acs, Z. J. (2013). Where angels fear to tread: Internationalization of emerging country SMEs. Journal of International Entrepreneurship, 11(3), 201-219.

Kingston, C., \& Caballero, G. (2009). Comparing theories of institutional change. Journal of Institutional Economics, 5(2), 151-180.

Kiss, A. N., \& Danis, W. M. (2008). Country institutional context, social networks, and new venture internationalization speed. European Management Journal, 26(6), 388-399. 
Kiss, A. N., \& Danis, W. M. (2010). Social networks and speed of new venture internationalization during institutional transition: A conceptual model. Journal of International Entrepreneurship, 8(3), 273-287.

Kiss, A. N., Danis, W. M., \& Cavusgil, S. T. (2012). International entrepreneurship research in emerging economies: A critical review and research agenda. Journal of Business Venturing, 27(2), 266-290.

Kobrin, S. J. (1982). Managing Political Risk Assessment: Strategic Response to Environmental Change. Berkeley, CA: University of California Press.

Kogut, B., \& Singh, H. (1988). The effect of national culture on the choice of entry mode. Journal of International Business Studies, 19(3), 411-432.

Konara, P., \& Shirodkar, V. (2018). Regulatory institutional distance and MNCs' subsidiary performance: Climbing up vs. climbing down the institutional ladder. Journal of International Management, 24(4), 333-347.

Koning, M., Mertens, G., \& Roosenboom, P. (2018). Drivers of institutional change around the world: The case of IFRS. Journal of International Business Studies, 49(3), 249-271.

Kostova, T., \& Marano, V. (2019). Institutional theory perspectives on emerging markets. In: Grosse, R., \& Meyer, K. E. (eds.) The Oxford Handbook of Management in Emerging Markets. New York: Oxford University Press. (pp. 99126).

Kostova, T., Roth, K., \& Dacin, M. T. (2008). Institutional theory in the study of multinational corporations: A critique and new directions. Academy of Management Review, 33(4), 994-1006.

Kshetri, N. (2010). Business perceptions of regulative institutions in Central and Eastern Europe. Baltic Journal of Management, 5(3), 356-377.

Lafuente, E., Stoian, M. C., \& Rialp, J. (2015). From export entry to deinternationalisation through entrepreneurial attributes. Journal of Small Business and Enterprise Development, 22(1), 21-37.

Levie, J., \& Autio, E. (2011). Regulatory burden, rule of law, and entry of strategic entrepreneurs: An international panel study. Journal of Management Studies, 48(6), 1392-1419. 
Li, T. (2018). Internationalisation and its determinants: A hierarchical approach. International Business Review, 27(4), 867-876.

Lim, D. S., Oh, C. H., \& De Clercq, D. (2016). Engagement in entrepreneurship in emerging economies: Interactive effects of individual-level factors and institutional conditions. International Business Review, 25(4), 933945.

Lin, D., Lu, J., Li, P. P., \& Liu, X. (2015). Balancing formality and informality in business exchanges as a duality: A comparative case study of returnee and local entrepreneurs in China. Management and Organization Review, 11(2), 315-342.

Lin, D., Lu, J., Liu, X., \& Zhang, X. (2016). International knowledge brokerage and returnees' entrepreneurial decisions. Journal of International Business Studies, 47(3), 295-318.

Lu, Y., Zhou, L., Bruton, G., \& Li, W. (2010). Capabilities as a mediator linking resources and the international performance of entrepreneurial firms in an emerging economy. Journal of International Business Studies, 41(3), 419-436.

Masron, T.A. (2017). Relative institutional quality and FDI inflows in ASEAN countries. Journal of Economic Studies, 44(1), 115-137.

McCain, K. W. (1990). Mapping authors in intellectual space: A technical overview. Journal of the American Society for Information Science (1986-1998), 41(6), 433-443.

Muralidharan, E., \& Pathak, S. (2017). Informal institutions and international entrepreneurship. International Business Review, 26(2), 288-302.

Ngo, V. D., Janssen, F., \& Falize, M. (2016). An incentive-based model of international entrepreneurship in emerging and transition economies. Journal of International Entrepreneurship, 14(1), 52-74.

Nikolaev, B. N., Boudreaux, C. J., \& Palich, L. (2018). Cross-country determinants of early-stage necessity and opportunity-motivated entrepreneurship: accounting for model uncertainty. Journal of Small Business Management, 56(sup1), 243-280. 
North, D. (1998). Five propositions about institutional change. In: Knight, J., \& Sened, I. (eds.) Explaining social institutions. Ann Arbor, MI: The University of Michigan Press. (pp. 15-26).

North, D. C. (1990). A transaction cost theory of politics. Journal of Theoretical Politics, 2(4), 355-367.

North, D. C. (1991). Institutions. Journal of Economic Perspectives, 5(1), 97-112.

Oparaocha, G. O. (2015). SMEs and international entrepreneurship: An institutional network perspective. International Business Review, 24(5), 861-873.

Peiris, I.K., Akoorie, M.E.M., \& Sinha, P. (2012). International entrepreneurship: a critical analysis of studies in the past two decades and future directions for research. Journal of International Entrepreneurship, 10, 279-324.

Peng, M. W., \& Khouri, T. A. (2008). Unbundling the institution-based view of international business strategy. In: Rugman, A. (Ed.). Oxford Handbook of International Business, Chapter 10. Oxford, UK: Oxford University Press. (pp. 256-268).

Peng, M. W., Wang, D.Y.L., \& Jiang, Y. (2008). An institution-based view of international business strategy: a focus on emerging economies. Journal of International Business, 39(5), 920-936.

Phillips, N., Tracey, P., \& Karra, N. (2009). Rethinking institutional distance: strengthening the tie between new institutional theory and international management. Strategic Organization, 7(3): 339-348.

Riddle, L., Hrivnak, G. A., \& Nielsen, T. M. (2010). Transnational diaspora entrepreneurship in emerging markets: Bridging institutional divides. Journal of International Management, 16(4), 398-411.

Riddle, L., \& Brinkerhoff, J. (2011). Diaspora entrepreneurs as institutional change agents: The case of Thamel. com. International Business Review, 20(6), 670-680.

Rottig, D. (2016). Institutions and emerging markets: effects and implications for multinational corporations. International Journal of Emerging Markets, 11(1), 2-17. 
Santamaria-Alvarez, S. M., Muñoz-Castro, D. C., Sarmiento-González, M. A., \& Marín-Zapata, S. I. (2018). Fragmented networks and transnational entrepreneurship: Building strategies to prosper in challenging surroundings. Journal of International Entrepreneurship, 16(2), 244-275.

Scott, W.R. (1987). The adolescence of institutional theory. Administrative Science Quarterly, 32, 493-511.

Scott, W. R. (1995). Institutions and organizations - Foundations for organizational science. London: Sage.

Scott, W. R. (2005). Institutional theory: Contributing to a theoretical research program. In Smith, K. G. \& Hitt, M. A. (Eds.). Great minds in management: The process of theory development. Oxford, UK: Oxford University Press.

Scott, W.R. (2010). Reflections: The past and future of research on institutions and institutional change. Journal of Change Management, 10(1), 5-21.

Shirokova, G., \& McDougall-Covin, P. (2012). The role of social networks and institutions in the internationalization of Russian entrepreneurial firms: Do they matter?. Journal of International Entrepreneurship, 10(3), 177-199.

Sigmund, S., Semrau, T., \& Wegner, D. (2015). Networking ability and the financial performance of new ventures: moderating effects of venture size, institutional environment, and their interaction. Journal of Small Business Management, 53(1), 266-283.

Stephan, U., \& Uhlaner, L. M. (2010). Performance-based vs socially supportive culture: A cross-national study of descriptive norms and entrepreneurship. Journal of International Business Studies, 41(8), 1347-1364.

Stephan, U., Uhlaner, L. M., \& Stride, C. (2015). Institutions and social entrepreneurship: The role of institutional voids, institutional support, and institutional configurations. Journal of International Business Studies, 46(3), 308331.

Su, J., Zhai, Q., \& Karlsson, T. (2017). Beyond red tape and fools: institutional theory in entrepreneurship research, 1992-2014. Entrepreneurship Theory and Practice, 41(4), 505-531. 
Surdu, I., Mellahi, K. \& Glaister, K. (2018). Emerging market multinationals' international equity-based entry strategies: review of theoretical foundations and future directions. International Marketing Review, 35(2), 342359.

Szyliowicz, D., \& Galvin, T. (2010). Applying broader strokes: Extending institutional perspectives and agendas for international entrepreneurship research. International Business Review, 19(4), 317-332.

Tallman, S. (1988). Home country political risk and foreign direct investment in the United States. Journal of International Business Studies, 19, 219-234.

Tang, Z., \& Tang, J. (2012). Entrepreneurial orientation and SME performance in China's changing environment: The moderating effects of strategies. Asia Pacific Journal of Management, 29(2), 409-431.

Tebaldi, E., \& Elmslie, B. (2013). Does institutional quality impact innovation? Evidence from cross-country patent grant data. Applied Economics, 45(7), 887-900.

Terjesen, S., \& Hessels, J. (2009). Varieties of export-oriented entrepreneurship in Asia. Asia Pacific Journal of Management, 26(3), 537-561.

Terjesen, S., Hessels, J., \& Li, D. (2013). Comparative international entrepreneurship: a review and research agenda. Journal of Management, 42(1), 299-344.

Tomizawa, A., Zhao, L., Bassellier, G., \& Ahlstrom, D. (2020). Economic growth, innovation, institutions, and the Great Enrichment. Asia Pacific Journal of Management, 37(1), 7-31.

Tung, R. L., \& Verbeke, A. (2010). Beyond Hofstede and GLOBE: Improving the quality of cross-cultural research. Journal of International Business Studies, 41, 1259-1274.

Ullah, I., \& Khan, M. A. (2017). Institutional quality and foreign direct investment inflows: evidence from Asian countries. Journal of Economic Studies, 44(6), 1030-1050. 
Urbano, D., \& Alvarez, C. (2014). Institutional dimensions and entrepreneurial activity: an international study. Small Business Economics, 42(4), 703-716.

Walder, A. G. (2011). From control to ownership: China's managerial revolution. Management and Organization Review, 7(1), 19-38.

Welter, F., \& Smallbone, D. (2011). Institutional perspectives on entrepreneurial behavior in challenging environments. Journal of Small Business Management, 49(1), 107-125.

Van Weele, M., van Rijnsoever, F. J., Eveleens, C. P., Steinz, H., van Stijn, N., \& Groen, M. (2018). Start-EU-up! Lessons from international incubation practices to address the challenges faced by Western European startups. The Journal of Technology Transfer, 43(5), 1161-1189.

Volchek, D., Jantunen, A., \& Saarenketo, S. (2013). The institutional environment for international entrepreneurship in Russia: Reflections on growth decisions and performance in SMEs. Journal of International Entrepreneurship, 11(4), 320-350.

Yang, M., \& Gabrielsson, P. (2018). The interface of international marketing and entrepreneurship research: Review, synthesis, and future directions. Journal of International Marketing, 26(4), 18-37.

Young, S. L., Welter, C., \& Conger, M. (2018). Stability vs. flexibility: The effect of regulatory institutions on opportunity type. Journal of International Business Studies, 49(4), 407-441.

Yousafzai, S. Y., Saeed, S., \& Muffatto, M. (2015). Institutional theory and contextual embeddedness of women's entrepreneurial leadership: Evidence from 92 countries. Journal of Small Business Management, 53(3), 587-604.

Zhang, M., Gao, Q., \& Cho, H. S. (2017). The effect of sub-national institutions and international entrepreneurial capability on international performance of export-focused SMEs: Evidence from China and South Korea. Journal of International Entrepreneurship, 15(1), 85-110.

Zhang, W., \& White, S. (2016). Overcoming the liability of newness: Entrepreneurial action and the emergence of China's private solar photovoltaic firms. Research Policy, 45(3), 604-617. 
Zettinig, P., \& Benson-Rea, M. (2008). What becomes of international new ventures? A coevolutionary approach. European Management Journal, 26(6), 354-365. 

Case of a Brazilian Information Technology Firm

\begin{abstract}
This study aimed at understanding the linkages between home country institutional voids and the internationalization of mature entrepreneurial firms, using the case study method of investigation. The study examines two issues: (i) how an entrepreneurial firm from a country with a weaker institutional environment can overcome national institutional voids and liabilities of foreignness, emergingness and outsidership, by expanding internationally, particularly to countries of high institutional quality; and (ii) how the firm employs specific legitimation practices to develop its cross-border activities. The study sheds light into the legitimation strategies used by an emerging market firm to overcome the liabilities of foreigness, emergingness and outsidership, and thus gain legitimacy in order to successfully establish itself as a global player in a high-tech industry.
\end{abstract}

\title{
3.1 Introduction
}

Institutional theory sees institutions as market-based mechanisms that provide informal and formal rules, thereby reducing uncertainty in transactions between different actors, and "establishing a stable structure to facilitate interactions" (Meyer, 2001, p.358). However, the institutional quality of a given country's environment may vary substantially, and firms must operate within the constraints imposed by their home country environment. The question of how firms operate in and adjust to different home/host country institutional environments has thus attracted the interest of International Business (IB) researchers. Yet the bulk of research has addressed these issues from the perspective of large multinational corporations (e.g. Abdi \& Aulakh, 
2012; Roy \& Oliver, 2009), and not from the perspective of domestic entrepreneurial firms in their internationalization process.

Moreover, despite the growing number of studies that have examined these issues, there is still a dearth of literature on how entrepreneurial firms from emerging economies have expanded internationally into markets that present very different institutional contexts. In fact, different outcomes are expected when entrepreneurial firms from emerging economies are compared to those from developed countries in their efforts to internationalize. Entrepreneurial firms from emerging economies suffer from regulatory and bureaucratic barriers to their internationalization processes and typically also from a lack of support for their efforts to internationalize (Cheng \& $\mathrm{Yu}$, 2008). In addition, when entering foreign markets they are faced with liabilities of foreignness, emergingness and outsidership, which may compromise their international expansion. Muralidharan and Pathak (2017, p.288) indicate specifically that the relationship between the home country's institutional environment and the internationalization of firms is a topic that "needs to be better understood and integrated into existing theoretical and conceptual frameworks."

Moreover, not only have entrepreneurial firms received less attention from IB researchers using institutional theory, but little research has been done using case studies to examine the international trajectory of these firms, as pointed out in the previous chapter of this thesis. The case study method of investigation is particularly useful when the phenomena of interest are processual, and when the context needs to be taken into consideration.

The present study uses the case method of investigation to answer the following research questions: (i) How can an entrepreneurial firm from an emerging market overcome national institutional voids by expanding internationally, particularly to countries of high institutional quality? and (ii) How does the firm employ specific legitimation practices to develop its cross-border activities? To answer these questions, the study adopts a longitudinal perspective of the internationalization process of an entrepreneurial firm from the Brazilian software industry - Stefanini IT - which is considered to be one of the most successful firms in the industry, and one of the most internationalized.

Hence, this study sheds additional light on the relationship between the internationalization process of entrepreneurial firms and the home country's institutional environment. In addition to the theoretical contribution, the study's results 
is also relevant to government agencies that promote the internationalization of indigenous firms. In fact, for government services to be effective in promoting international activities, as well as other services provided by private and non-profit entities, it should be helpful to understand how an emerging market firm can successfully gain legitimacy in developed markets. Such knowledge can better direct the efforts and resources allocated to promote the internationalization of firms from an emerging economy such as Brazil.

\section{2}

\section{Theoretical Background}

Institutional quality and prosperity seem to be related. In countries with high levels of institutional quality (Rodrik, 2004): (i) property rights are guaranteed, encouraging investors; (ii) the rule of law predominates; (iii) private and social goals are aligned; (iv) solid economic institutions are the basis for monetary and fiscal policies; (v) social insurance protects against extraordinary losses; and (vi) citizens are politically represented and their civil rights are assured. Countries with low levels of institutional quality are countries where all these characteristics are absent or not regularly found. High levels of institutional quality are usually related to developed, rich countries and low levels of institutional quality usually involve less developed, poor countries. However, since the direction of the causal relationship between institutional quality and economic development can go both ways, a country with low institutional quality may introduce changes that could strengthen institutions and thus promote economic growth (Rodrik, 2004).

Although early studies indicated that institutional quality had a geographical component (resources, latitude), more recent research on institutional quality shows that geography has almost no direct effect on income and economic growth (Rodrik, 2017). Acemoglu, Johnson and Robinson (2001) suggest that Western European countries have historically been associated with high quality institutions, but this is not surprising given the historical evolution of those societies. Tomizawa et al. (2020) investigated the causes of economic growth in several countries, finding evidence that productivity, innovation, new ventures, new markets, improved standards of living and positive institutions are factors that support the development of entrepreneurship and economic development. 
Research involving entrepreneurship and institutional theory has most often adopted a comparative approach, examining how the quality of the institutional environment impacts the emergence of entrepreneurship in a variety of countries. The low institutional quality of the home country - a typical situation in emerging economies - tends to create difficulties not only for the emergence of entrepreneurial firms, but also for their growth. Adomako et al. (2019, p. 2) point out that "differences in the national supportiveness and quality of the institutional environment remain a major problem facing firms [...] especially in Africa and unstable environments, such as those found in emerging economies."

In a literature review of studies linking entrepreneurship to the quality of formal and informal institutions, Salimath and Cullen (2010, p.372) provide support to the general consensus on the positive relationship between entrepreneurship and institutional quality, and to considering "external environment conditions as appropriate for explaining the process of entrepreneurship at the national level." Bowen and De Clercq (2008) use data from 40 countries and aver that gearing entrepreneurial efforts toward high-growth activities is positively related to a country's financial and educational systems targeting entrepreneurs, and negatively related to the level of corruption. There is also evidence that entrepreneurial activity tends to be impacted by financial limitations: while in developed economies it is easier for entrepreneurs to access credit, in developing countries it is harder for entrepreneurs to access credit (Escandon-Barbosa, Urbano-Pulido \& Hurtado-Ayala, 2019). Audretsch and Caiazza (2016, p.1252) indicate that "supported from institutional factors, entrepreneurship becomes a channel able to transform knowledge created, transformed and spilled over sources in economic growth." They call attention to the role of institutional support in promoting the emergence of technological competencies and indicate that formal institutions, namely regulatory institutions, industrial structure, availability of venture capital, and incubators may all play a major role in encouraging the evolution of technology start-ups.

\subsection{1 Institutional voids}

Khanna and Palepu (1997) coined the term "institutional voids" to designate the lack or failure of reliable institutions to support efficient and effective market 
transactions. Subsequently, Khanna, Palepu and Sinha (2005) developed the concept further, using several examples to illustrate its manifestations. Table 1 compiles and summarizes the ideas expressed in both articles. According to these articles, many institutions in emerging markets fail at supporting basic business operations. The political and social systems and the degree of openness of the economy shape the market contexts. Foreign firms must learn how to deal with differences in product, capital and labor markets in emerging markets, as well as with differences in government regulations. Because governments intervene much more heavily in business decisions, there is a tendency for there to be substantial bribery and corruption, as well as bureaucracy. Companies may have a difficult time communicating with their customers due to deficiencies in the communications infrastructure. Moreover, the lack of a strong educational system impacts the ability to hire skilled employees. Investors may also become discouraged due to limited access to information and reliable financial reporting. Strict labor laws prevent companies from laying off employees, and there is also a lack of government-provided unemployment benefits. Capital and financial markets in emerging economies have few stock exchanges and government-appointed regulators, with no reliable intermediaries such as credit-rating agencies, investment analysts, merchant bankers, or venture capital firms. As a result, firms must operate with the higher costs of complexity and coordination in a highly uncertain institutional context.

Table 1 - Institutional Voids

\begin{tabular}{|l|l|}
\hline Institutional Voids & Selected examples \\
\hline Political and Social & $\begin{array}{l}\text { Unbalanced distribution of power among the central, state and city } \\
\text { governments. } \\
\text { Lack of independence of the judiciary }\end{array}$ \\
\hline $\begin{array}{l}\text { Government } \\
\text { Regulations }\end{array}$ & $\begin{array}{l}\text { State intervention in business operations } \\
\text { Uncertainty of regulatory systems } \\
\text { High levels of corruption }\end{array}$ \\
\hline Contract enforcement & $\begin{array}{l}\text { Lack of effective mechanisms to enforce contracts } \\
\text { Unpredictability of decisions by the judicial system } \\
\text { Private property rights inefficiently protected by laws }\end{array}$ \\
\hline Capital Markets & $\begin{array}{l}\text { Unreliable financial reporting, a non-dynamic community of } \\
\text { analysts, and a non-aggressive, dependent financial press. } \\
\text { Ineffective banking systems } \\
\text { Unreliable corporate performance information }\end{array}$ \\
\hline Labor Markets & $\begin{array}{l}\text { Scarcity of well-trained people } \\
\text { Few strong educational institutions for technical and management } \\
\text { training } \\
\text { Limited knowledge and fluency in English } \\
\text { Lack of a standard practice for pay for performance }\end{array}$ \\
\hline
\end{tabular}




\begin{tabular}{|l|l|}
\hline Product Markets & $\begin{array}{l}\text { Underdeveloped communications and transportation infrastructures } \\
\text { Lack of information, mechanisms, organizations and liability laws } \\
\text { (and their enforcement) to protect consumers } \\
\text { Weak network of suppliers } \\
\text { Higher costs to develop credible brands }\end{array}$ \\
\hline Openness & $\begin{array}{l}\text { Government restrictions on foreign investments } \\
\text { Burdensome procedures for starting new ventures }\end{array}$ \\
\hline
\end{tabular}

Source: Compiled and adapted from Khanna and Palepu, 1997; Khanna, Palepu and Sinha, 2005.

Without referring specifically to institutional voids, several authors have examined the influence of formal institutional voids (governments' political, economic, and legal or regulatory institutions, property rights protection, infrastructure, and rule of law) (Pinkham \& Peng, 2017; Puffer, McCarthy \& Boisot, 2010; Webb et al., 2010). Interestingly, most of the literature examines institutional voids in the context of emerging markets. Nevertheless, Bendickson et al. (2020) argue that there are often pockets of institutional weakness within developed countries. They examined the specific situation of the city of Detroit, which went through a period of deinstitutionalization.

Prashantham, Eranova and Couper (2018, p.6) point out that institutional voids "constitute a major impediment to economic development in less developed parts of the world," a position shared by most scholars. Nevertheless, three studies in the bibliometric review (Essay 1) show that institutional voids in emerging countries can have both a negative and a positive effect on firm internationalization. Adomako et al. (2019) argue that institutional voids may have a positive influence on the internationalization of new ventures. Their study was based on new ventures in Ghana, and the results indicated that home country institutional voids help new ventures with their internationalization strategy, and that the firm's international learning effort when entering a host market is a mediator of the host country's environmental dynamism and competitive intensity. Thus, according to the authors, new ventures from emerging economies can engage in innovative activities in new markets by learning new capabilities. Bruton et al. (2014) studied the various impacts of institutions on high technology firms in China, Poland and Russia, and found that the main similarity between these national environments was their institutional background as communist countries, with controlled politics, economy and social life, which tended to yield similar institutional voids. These institutional voids were regarded as favorable for developing strategic orientations and gaining legitimacy in new host markets. Looking 
specifically at social entrepreneurship, Chen, Saarenketo \& Puumalainen (2016) argue that due to the negative reputation of their countries of origin, new ventures from Latin American countries are less likely to advance in their internationalization strategies than are new ventures from emerging markets in other regions. On the other hand, homecountry institutional voids trigger cross-border social entrepreneurial opportunities.

Several studies have shown that entrepreneurs from emerging economies make use of network and social ties to overcome institutional voids, by accessing local networks, such as suppliers and partners at the host countries (Lu et al., 2010; Walder, 2011; Danis, Chiaburu \& Lyles, 2010; Kiss \& Danis, 2008, 2010; Zettinig \& BensonRea, 2008; Oparaocha, 2015; Shirokova \& McDougall-Covin, 2012; Volchek, Jantunen \& Saarenketo, 2013) Based on these considerations, Puffer, McCarthy and Boisot (2010) suggest that entrepreneurship in emerging markets differs from that in more developed economies, and, therefore, deserves more scholarly attention.

\subsection{2 Internationalization and the institutional environment}

The literature examining the relationship between a country's institutional environment and the internationalization of firms has followed several different paths. Initially, a large part of the studies focused on how firms from developed countries enter host countries that have a low level of institutional quality (e.g. Elg, Ghauri, Child, \& Collinson, 2017; Luo, 2005; Papyrina, 2007). This literature is usually concerned with how MNEs from developed countries deal with weak institutions in host countries. For example, Meyer et al. (2009) found that MNEs from high-quality institutional environments use joint ventures to gain access to resources when they enter countries with low quality institutions, but they prefer acquisitions when the host country's institutional environment is strong. However, few studies have looked at how entrepreneurial firms from emerging markets respond to a large institutional distance to the host market. An exception is the study by Deng and Sinkovics (2018), which examined variations in the speed of internationalization of new ventures from emerging markets, depending on the institutional characteristics of the host market.

A second stream in this literature is concerned with home country institutional voids that affect EMNEs, and the impact on their choice of foreign markets and entry strategies (e.g. Gammeltoft, Pradhan, \& Goldstein, 2010; Wu et al., 2016). Concerning 
EMNEs specifically, Kostova and Marano (2019) classify IB studies into three broad areas: (i) the characteristics of the business environment in emerging markets, including institutional voids and institutional change; (ii) the interface between the firm and the institutional environment, including issues associated with MNEs' operations in emerging markets and EMNEs' expansions into foreign markets; and (iii) challenges faced by organizations "in and from emerging markets" (p.101) and their responses to these challenges. For example, Hobdari et al. (2017) studied EMNEs and linked institutions and resources in emerging market home countries to their domestic business eco-system. Webb, Khoury and Hitt (2020) proposed a framework to show how formal and informal institutional voids influence entrepreneurial activities in a particular country, and Yaprak, Yosun and Cetindamar (2018) examined a country's specific factors that, in addition to firm-specific factors, influence the internationalization strategy of firms from emerging markets. Among the country-specific factors, firm adaptability was a positive outcome of home country institutional voids.

Lastly, the third approach looks at how a firm's home country institutional environment influences its international choices (e.g. Liu \& Yu, 2018; Tang \& Buckley, 2020). A limited number of studies have looked specifically at how the home country's institutional environment either promotes or discourages the internationalization of entrepreneurial firms. For example, two studies examined the impact of home country factors on the internationalization of Chinese firms (Han, Liu, Xia \& Gao, 2018; Wei, Clegg \& Ma, 2015). Terjesen and Hessels (2009) found that Asian countries with high quality institutions are more likely to have higher proportions of young export-oriented firms. Furthermore, their study revealed that countries with higher proportions of export-oriented entrepreneurial activity tend to have flexible industrial relations, high quality vocational training, and confrontational labor-employer relations. Also, GarciaCabrera et al. (2016) observed that the three pillars of the institutional environment may impact entrepreneurial firms' decision to internationalization, and Chen, Saarenketo and Puumailanen (2018) determined that the likelihood of firm internationalization is increased in countries with higher quality formal institutions. 


\subsection{3}

\section{Liabilities of foreignness, emergingness and outsidership}

Scholars have recognized three major types of liabilities when a firm enters a foreign market: liabilities of foreignness, emergingness, and outsidership. If the new entrant is a small, young firm, there is also a liability of newness, which, however, also applies to a domestic market.

When a firm enters a new international market, it suffers from liabilities of foreignness, a construct advanced by Zaheer (1995) to designate the costs incurred by a firm when entering a foreign country in comparison with domestic firms. Gaur, Kumar and Sarathy (2011, p.211) argue that liabilities of foreignness originate from two sources: the environment and the firm. The "environmentally-derived liability of foreignness" comes from the unknown environment outside the firm in home and host country. The "firm-based liability of foreignness" is related to characteristics of the firm, such as its ownership structure, affiliation or resources. These sources may differ whether the firm comes from a developed or an emerging economy. Sethi and Judge (2009) study the costs of doing business abroad and treat liabilities of foreigness as one component of these costs, because other costs are related to another construct they named "liabilities of multinationality." They classify the costs involved in liability of foreigness in two categories: discriminatory and incidental. They also claim there are "assets of foreignness" (p.406). Table 2 presents these costs and assets according to the authors.

Table 2 - Liabilities and Assets of Foreignness

\begin{tabular}{|l|l|l|}
\hline Costs/Benefits & Liabilities/ Assets of \\
\hline $\begin{array}{l}\text { Costs of doing } \\
\text { business abroad }\end{array}$ & Discriminatory & $\begin{array}{l}\text { Costs of economic nationalism and prejudice against } \\
\text { foreign firms } \\
\text { Costs of host government restrictions and hostility }\end{array}$ \\
\cline { 2 - 3 } & Incidental & $\begin{array}{l}\text { Costs of lack of local information } \\
\text { Costs of cultural differences } \\
\text { Costs of lack of local relationships } \\
\text { Costs of not being isomorphic with local institutional } \\
\text { environment }\end{array}$ \\
\hline $\begin{array}{l}\text { Benefits of doing } \\
\text { business abroad }\end{array}$ & $\begin{array}{l}\text { Incentives from host government } \\
\text { Brand image and superior proprietary technology } \\
\text { First-mover advantages } \\
\text { Ability to influence national legislation and policy }\end{array}$ \\
\hline
\end{tabular}

Source: Sethi and Judge (2009, p. 406) 
A related concept that appears in the literature is liability of origin, conceptualized by Shapiro, Li and Feng (2020, p.1) as "disadvantages faced by firms sharing common national origins." However, according to Sethi and Judge's (2009) list, this concept is a manifestation of the liability of foreignness, while Marano, Tashman and Kostova (2017) associate this construct to emergingness.

If the new entrant is from an emerging market, it also suffers from a liability of emergingness (Tiwari et al., 2016). In both cases, the new entrant needs to build legitimacy to effectively operate in the foreign market. Zhou (2018) studied emerging market multinationals and distinguishes the constructs of liability of foreignness and liability of emergingness. He argues that liability of emergingness is a broader concept which includes the liability of foreignness. According to Zhou (2018), the liability of emergingness includes three types of costs: government-related, customer-related, and organization-related.

Another type of liability faced by firms entering a foreign market is the liability of outsidership. Johanson \& Vahlne (2009) describe this liability as the opposite of insidership in relevant networks. To guarantee the success in internationalization, a firm entering a foreign market has to oversome the liability of outsidership, that is, not to belong to any relevant network in the foreign market. This conceptualization is an evolution of these authors' original step-by-step model. Outsidership in relation to networks in a host country would have a more profound impact on internationalization than psychic distance, because of the uncertainty it generates (Johanson \& Vahlne, 2009, p. 1411). Vahlne, Schweizer and Johanson (2012, p. 224) argue that liabilities of outsidership are also responsible for the lack of knowledge of a multinational's headquarters about the actions of its subsidiaries. On a later paper, Vahlne and Johanson (2017) explain that the liability of outsidership can be understood as a manifestation of a firm's resource scarcity.

\subsection{4}

\section{Legitimacy}

Suddaby, Bitektine and Haack (2017, p.451) claim that legitimacy is "a pivotal but often confusing construct." In institutional theory, legitimacy refers to how organizations secure positions by complying with the rules of the institutional environment (Meyer \& Rowan, 1977; Scott, 1987). Zhang et al. (2020, p.1) see 
legitimacy as "the overall assessment of the appropriateness of organizational ends and means." Gaining legitimacy is thus an ethical issue that impacts emerging market multinationals because "enables them to succeed in foreign markets." Scholars also recognize different dimensions of legitimacy. Aldrich and Fiol (1994) propose that legitimacy can have two dimensions: cognitive legitimacy and sociopolitical legitimacy. The former has to do with how much a new firm is known, and the latter involves how stakeholders accept the firm once its rules and norms are recognized to conform to the standard. Zhang et al. (2020) identify four dimensions of legitimacy in the literature: regulatory, moral, pragmatic and cultural-cognitive (Table 3). The socio-political dimension of Aldrich and Fiol (1994) seems to incorporate the characteristics of the regulatory and pragmatic dimensions in Zhang et al.'s (2020) classification.

Table 3 - Dimensions of Legitimacy

\begin{tabular}{|l|l|}
\hline Dimension & Characteristics \\
\hline Regulatory & $\begin{array}{l}\text { "conforming to laws and rules set forth by governments and other } \\
\text { regulatory authorities." }\end{array}$ \\
\hline Moral & "adhering to the norms and values of society" \\
\hline Pragmatic & $\begin{array}{l}\text { "satisfying stakeholders' self-interests based on direct exchanges, consistent } \\
\text { with the economic responsibilities of the corporation" }\end{array}$ \\
\hline $\begin{array}{l}\text { Cultural- } \\
\text { cognitive }\end{array}$ & achieving "recognizability, comprehensibility, and cultural support" \\
\hline
\end{tabular}

Source: Compiled from Zhang et al. (2020, p.7)

Emerging market firms face liabilities of foreignness and may not be familiar with the regulatory system of a foreign country. However, moral legitimacy is considered a key type of legitimacy a firm needs to operate in a foreign market. For an emerging market firm, this dimension is even more critical, because of the lack of familiarity with the values and norms dominant in a foreign market, at the same time different stakeholders are not familiar with the firm's home country values and norms. Thus, according to Zhang et al. (2020), emerging market firms face both liabilities of foreigness and emergingness associated to this dimension of legitimacy. There are also concerns in advanced countries of whether emerging market firms can provide satisfactory products and services to consumers, although they are viewed as providing jobs and opportunities for local citizens. These aspects of pragmatic legitimacy are more related to liabilities of emergingness. Finally, since the cultural-cognitive dimension has to do with the extent to which a firm is known in a foreign country, this dimension is also related to the liabilities of foreignness and emergingness. 
The big question concerning legitimacy in international business is how do firms gain legitimacy, particularly firms from emerging markets that have to overcome the liabilities of foreignness, emergingness and outsidership, and, if they are young, also the liabilities of newness. From a more generic perspective, Aldrich and Fiol (1994) divides the strategies to gain legitimacy in four levels: organizational, intraindustry, interindustry and institutional (Table 4).

Table 4 - Dimensions of Legitimacy and Strategies to Gain Legitimacy

\begin{tabular}{|c|c|c|}
\hline \multirow[t]{2}{*}{ Level of Analysis } & \multicolumn{2}{|c|}{ Type of Legitimacy } \\
\hline & Cognitive & Sociopolitical \\
\hline Organizational & $\begin{array}{l}\text { Develop knowledge base via } \\
\text { symbolic language and behaviours }\end{array}$ & $\begin{array}{l}\text { Develop trust in the new activity } \\
\text { by maintaining internally } \\
\text { consistent stories }\end{array}$ \\
\hline Intraindustry & $\begin{array}{l}\text { Develop knowledge base by } \\
\text { encouraging convergence around a } \\
\text { dominant design action }\end{array}$ & $\begin{array}{l}\text { Develop perceptions of reliability } \\
\text { to take collective action }\end{array}$ \\
\hline Interindustry & $\begin{array}{l}\text { Develop knowledge base by } \\
\text { promoting activity through third- } \\
\text { party actors }\end{array}$ & $\begin{array}{l}\text { Develop reputation of a new } \\
\text { activity as a reality negotiating and } \\
\text { compromising } \quad \text { with } \\
\text { industries }\end{array}$ \\
\hline Institutional & $\begin{array}{l}\text { Develop knowledge } \text { base creating } \\
\text { linkages } \quad \text { with } \\
\begin{array}{l}\text { educational efforts } \\
\text { established }\end{array}\end{array}$ & $\begin{array}{l}\text { Develop legitimacy by organizing } \\
\text { marketing lobbying efforts }\end{array}$ \\
\hline
\end{tabular}

Source: Aldrich and Fiol (1994, p. 649)

Kostova, Roth and Dacin (2008) challenge the traditional explanations of institutional theory relative to the search of legitimacy by MNEs. While institutional theory suggests that in order to gain legitimacy firms accept isomorphic pressures from the institutional environment, thus becoming more similar, these authors claim that MNEs "engage in actor-specific manipulation and negotiation of their status aimed at social construction of their acceptance and approval" (p.1000). Therefore, the process of acquiring legitimacy would actually make firms less similar. Negotiation involves establishing communication, relationships and exchange with key actors, and associating the organization (or parts of it) with "other highly legitimate units" (p.1001). In addition, these authors claim that the process of building legitimacy by MNEs is to a large extent symbolic.

Gaining legitimacy is certainly more difficult for small, young firms than for large, mature ones. Two studies provide intriguing insights into the process of legitimation of smaller entrepreneurial firms in international markets (Turcan \& Fraser, 2016; Zhang \& White, 2016). Turcan and Fraser (2016) argue that empirical research 
on the internationalization and legitimation of international new ventures from emerging economies is scarce. They explain that there are three different forms in which legitimation can happen: legitimation of the new industry, legitimation of the new venture domestically, and legitimation of the new venture internationally. Symbolic legitimation strategies for new ventures are: credibility (personal capability and personal commitment to the venture); professional organizing (professional structures and processes); organizational achievement (products and technologies), age of the venture and the number of employees; and quality of the stakeholders (Turcan \& Fraser, 2016). There are a couple of ways for a firm to achieve legitimation: they can search for a favorable geographic location in the host country; they can act in conformance with similar rules and values such as those found in local organizations. Their findings indicate that there are four important factors for a new venture from an emerging country to achieve cognitive and sociopolitical legitimacy: a robust business model; strong, persuasive arguments based on host market beliefs; the promoting of local incentives; the use of technology legitimation strategies to overcome liability of emergingness. Zhang and White (2016) studied how entrepreneurs from China's private solar photovoltaic firms can build legitimacy and capabilities to overcome significant liabilities of newness. They suggest three strategies: a firm can maximize its existing sources of legitimacy; it can conform to local rules and norms; it can convince the host institutional environment to change its perceptions of legitimacy. They suggest that government policies and actions can create an environment in which experimentation and exploration is legitimate, making it easier for entrepreneurs, new ventures and new organizational forms to access critical resources and realize their potential.

\section{3 \\ Method}

The research adopted the case study method of investigation. The study uses a single case and adopts a longitudinal perspective. The case was selected with the specific purpose of exploring the process of legitimation (gaining legitimacy) of an emerging economy firm in a developed market possessing higher quality in the institutional environment, with a focus on how the firm overcame the institutional voids of the home country. A single case is considered appropriate to explore a theory in more 
depth and to provide additional insights to the existing knowledge on the research problem (Ghauri, 2004). This specific case showed a priori all the conditions for examining the theoretical issues under investigation.

The Brazilian software industry is the locus of the study. The following criteria were used to select the case: (i) the firm had to have reached a leading position in the Brazilian software industry; (ii) it had to have a successful internationalization path; (iii) secondary data about the firm would have to be available to permit a longitudinal study; and (iv) the firm's top management would have to agree to participate in the study. Four companies were identified that met the first three criteria (Totvs, CI\&T, Módulo and Stefanini IT). Because of the broad availability of secondary data, the firm Stefanini IT was selected and it agreed to participate. Characteristics of the firm are presented in Table 5, followed by a short description of the firm's internationalization process.

Table 5 - Characteristics of the Case Selected

\begin{tabular}{|l|c|}
\hline Firm Characteristics & Stefanini IT Solutions \\
\hline Home country & Brazil \\
\hline Year of inception & 1987 \\
\hline $\begin{array}{l}\text { Year internationalization } \\
\text { started }\end{array}$ & 1996 \\
\hline Total sales in 2020 & R\$ 4.0 billion \\
\hline Main product line & Applications, ITO, BPO, Software Solutions, Business \\
\hline
\end{tabular}

The study used both primary and secondary data. The sources included the company's website, articles published in business newspapers and magazines, a biographical book and academic articles that examined the firm (Table 6). Data triangulation was facilitated by the large amount of data available from different sources (Eisenhardt, 1989; Ghauri, 2004).

Table 6 - Summary of data sources

\begin{tabular}{|l|c|}
\hline Data Sources & Number \\
\hline News and interviews in the press & 72 \\
\hline Company website & 01 \\
\hline Academic articles & 05 \\
\hline Books & 01 \\
\hline
\end{tabular}


The primary data were collected using virtual interviews, with the support of a semi-structured script. Two in-depth interviews took place in March of 2021, generating 64 pages of transcripts (Table 7)

Table 7 - Interviewee Profile

\begin{tabular}{|l|l|}
\hline Name & Position \\
\hline Ailtom Barberino & Global Executive Vice-President \\
\hline Carla Ferber & Head of Marketing North America \\
\hline
\end{tabular}

The analysis adhered to the following protocol. First, a detailed description of the case history was done using secondary data and data from the in-depth interviews. Second, the study used within-case analysis, that is, an in-depth study of a single case (Miles \& Huberman, 1994). Third, the findings were compared with those in the literature (pattern-matching analysis).

A limitation of case studies is that they do not permit statistical generalization (Yin, 2017); that is, the results from a case are limited to the specific firm studied and cannot be extended to other firms in the population. Nevertheless, the method does allow for analytical generalization; that is, the results can help to clarify the conceptual domain of the constructs under study, as well as to arrive at theoretical propositions to be tested in future research. As pointed out by Welch, Piekkari, Plakoyiannaki and Paavilainen-Mäntymäki (2011, p.746), such limitation "does not preclude case studies from having a strong explanatory contribution to offer." Other limitations are associated to the small number of interviews, but this was partially overcome by the large availability of secondary data.

\section{4}

\section{The Brazilian Information Technology Industry}

The Brazilian information technology (IT) industry appeared in the 1970s and was protected by the Information Technology Law of 1984, which lasted until 1992. This law intended to protect domestic firms in the hardware segment of the industry, but it ended by supporting the birth and growth of a large number of small and mediumsized enterprises in the software and services segment of the IT Industry. With the end 
of market protection, most hardware manufacturers were unable to compete. However, in the software segment several firms prospered (Da Rocha, Moraes \& De Mello, 2020).

In 2019, Brazilian domestic IT market sales accounted for US\$ 44.3 billion, divided into software (US\$ 10.3 billion), services (US\$ 11.1 billion) and hardware (US\$ 22.9 billion). Although Brazil occupied the $10^{\text {th }}$ position in the world IT ranking, only $2.6 \%$ of total industry output was exported. Nevertheless, exports of software have increased by $29 \%$ in 2019 , compared to the previous year. In 2019 , over 20,000 companies were operating in the software and services industry, with around half of them involved in distribution and marketing activities (Associação Brasileira das Empresas de Software, 2020).

\section{5 \\ The Case Stefanini IT Solutions}

\subsection{1 \\ Background}

Stefanini IT Solutions was founded in 1987 in São Paulo, Brazil. Its core business at the time was to develop business software and to offer outsourcing services. In 1995, the company started national expansion into other major cities in Brazil. The decision to internationalize was made in 1996, a time when new international players were entering the Brazilian market. Strategic clients entering international markets offered an attractive business opportunity in a troubled domestic market with few incentives. Consequently, Stefanini followed one of its clients, a large Brazilian bank, to Argentina and acquired a local company there.

Subsequently, the firm entered other countries of Mercosur (the Southern Latin American Common Market). The next international move was outside Latin America, this time to the United States in 2001, opening an office in Florida. Between 2003 and 2006, Stefanini entered the Asian and the European Markets (Spain, Portugal, Italy, UK, India, China, etc.). Starting in 2015, the expansion continued to countries such as Greece, Morocco, Finland, Malaysia, Singapore and Israel, the last one through a joint venture with a local company.

In 2020, the company had 71 offices in 69 cities in 41 countries around the world. That same year, Stefanini had sales of around R\$ 4 billion and over 25,000 
employees worldwide. Table 8 presents company data and Figure 1 shows the firm's sales trajectory. Considering values in the domestic currency (reais), the company increased its sales by $20 \%$ from 2019 to 2020 .

Table 8 - Stefanini IT Solutions data (estimated)Erro! Indicador não definido.

\begin{tabular}{|l|c|}
\hline Indicator & $\mathbf{2 0 2 0}$ \\
\hline Sales Revenue & US\$ 786.596.397 \\
\hline Employees & 25.000 \\
\hline In the country & 13.000 \\
\hline Abroad & 12.000 \\
\hline
\end{tabular}

Source: CNN Brasil Business, 2020

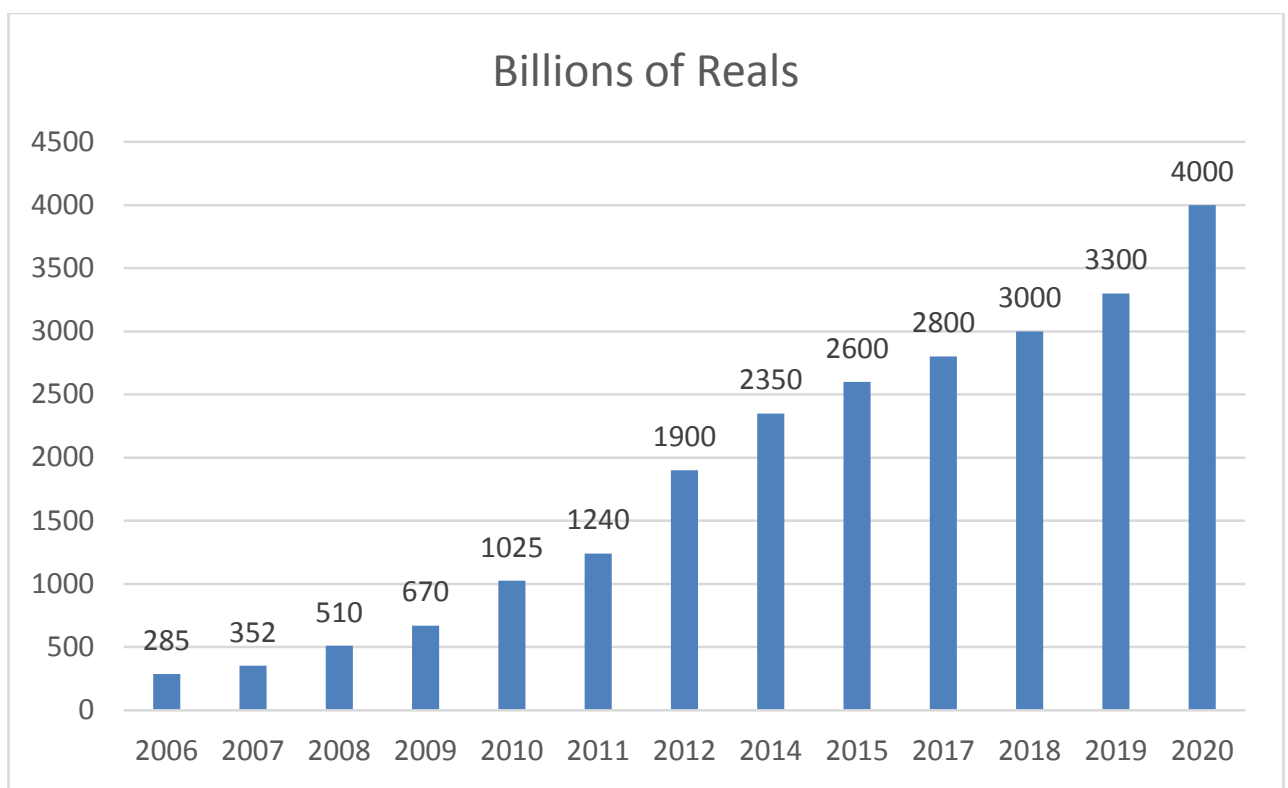

Figure 1 - Sales Growth (in billions of reals)

Source: prepared based on Stefanini Fact Sheet (2021)

Table 9 presents an overview of the main events that shaped Stefanini's trajectory since its inception.

Table 9 - Stefanini IT Time Line

\begin{tabular}{|l|l|}
\hline Year & Main Events \\
\hline 1987 & Start of activities with an office in Marco Stefanini’s house. \\
\hline 1989 & Opening of training courses for professionals from large companies. \\
\hline 1990 & Beginning of outsourcing services. \\
\hline 1991 & Expansion of outsourcing services. \\
\hline 1992 & Transfer from mainframe to new technologies. \\
\hline 1993 & Outsourcing and operation and production services. \\
\hline 1994 & First software factories; Growth close to $200 \% ;$ \\
\hline
\end{tabular}




\begin{tabular}{|c|c|}
\hline & Beginning of social responsibility projects. \\
\hline 1995 & $\begin{array}{l}\text { Beginning of national expansion with opening of branches in Campinas, Curitiba } \\
\text { and Porto Alegre; Opening of the new office in São Paulo. }\end{array}$ \\
\hline 1996 & $\begin{array}{l}\text { Obtaining ISO 9001; First international acquisition in Argentina; Partnership with } \\
\text { SAP; Expansion of activities (ERP) }\end{array}$ \\
\hline 1997 & $\begin{array}{l}\text { Opening of branches in Belo Horizonte and Rio de Janeiro; Creation of the } \\
\text { Networking division }\end{array}$ \\
\hline 1998 & $\begin{array}{l}\text { Opening of a branch in Fortaleza; Expansion of software factories across the } \\
\text { country. }\end{array}$ \\
\hline 1999 & Opening of a branch in Recife. \\
\hline 2000 & $\begin{array}{l}\text { Opening of a branch in Salvador and a subsidiary in Chile; Launch of CRM and } \\
\text { BI services. }\end{array}$ \\
\hline 2001 & $\begin{array}{l}\text { Opening of a branch in Brasilia and subsidiaries in Peru, Colombia and Mexico; } \\
\text { Opening of office in Fort Lauderdale, USA }\end{array}$ \\
\hline 2002 & Achievement of Capability Maturity Model (CMM) level 2. \\
\hline 2003 & Opening of a branch in Spain \\
\hline 2004 & $\begin{array}{l}\text { Opening of a branch in Portugal; operations in Angola; Achievement of CMM } \\
\text { level 3. }\end{array}$ \\
\hline 2005 & Opening of offices in New York (U.S.) and Italy; Achievement of CMM level 5. \\
\hline 2006 & Opening of offices in England and India. \\
\hline 2007 & Inclusion in The Black Book Outsourcing \\
\hline 2008 & Opening of a branch in Canada \\
\hline 2009 & Creation of Stefanini Document Solutions \\
\hline 2010 & Acquisitions of two firms in Brazil and of TechTeam in the U.S. \\
\hline 2011 & $\begin{array}{l}\text { Acquisitions in Colombia (Informatica \& Tecnología) and the U.S. (CXI); } \\
\text { Opening of branches in the Philippines and China. }\end{array}$ \\
\hline 2012 & Aquisition of companies in Brazil; Opening of a branch in South Africa. \\
\hline 2013 & Acquisition of a company in the U.S. (RCG Staffing) \\
\hline 2014 & $\begin{array}{l}\text { Strengthening of Business Consulting; Creation of Datastorm (company focused } \\
\text { on Big Data); Attainment of ISO } 27001\end{array}$ \\
\hline 2015 & $\begin{array}{l}\text { Merger with IHM Engenharia, joint venture with Tema Sistemas to create } \\
\text { Stefanini Capital Market and creation of Inspiring company, focused on } \\
\text { telecommunications; Acquisition of } 40 \% \text { of Saque e Pague; Opening of office in } \\
\text { Ontario (Canada) and Singapore }\end{array}$ \\
\hline 2016 & $\begin{array}{l}\text { Acquisition of the Colombian company Sysman; merger of an affiliate with Scala } \\
\text { IT; joint venture with the Israeli company Rafael. }\end{array}$ \\
\hline 2017 & $\begin{array}{l}\text { Obtaining ISO } 14001 \text { and the CarbonNeutral }{ }^{\circledR} \text { certificate; Acquisition of Gauge } \\
\text { in Brazil }\end{array}$ \\
\hline 2018 & $\begin{array}{l}\text { Acquisition of the companies Estatística Segura, Magma (health vertical) and } \\
\text { Intelligenti (management of labor claims) all in Brazil }\end{array}$ \\
\hline 2019 & Aquisition of TecCloud in Brazil \\
\hline
\end{tabular}

Source: organized based on Stefanini Fact Sheet (2021) and articles in the press.

\subsection{2}

\section{Internationalization trajectory}


The company's international trajectory can be divided into four waves, as explained by Global Vice President Ailtom Barberino:

"We came up with a new internationalization plan and divided the process into four waves. We did the first wave, which was for the Latin markets. That gave us bit of experience. Then the second wave, which consisted of entering more daring markets. The third wave was for accessing markets outside the continent. That's what we did: Latin America for initial experience; then growth and entry into the United States; the third expansion was to markets outside the Americas, on other continents. The fourth wave, which is still in progress, was expanding by means of acquisition."

The first wave, which began in 1996 with the opening of the first international subsidiary in Argentina, lasted until 2000. With the entry of multinationals into the Brazilian market, small local technology companies were threatened by the new global competition. This was the main reason for Stefanini seeking its first international acquisition at the time, a small Argentine company. Ailton Barberino, Global Vice President of Stefanini recalled:

"I was at working at Itaú, but I know the story very well. What happens is that Stefanini, at that moment, started to notice the entry of multinationals in the Brazilian market. Given the size of these global companies, these moves threatened companies that were still small. Marco Stefanini decided then that the company needed to explore other markets. There was an opportunity for an acquisition of a small company in Argentina. Marco had already had contact with the owners of that company. The Argentinian company was acquired and Stefanini's internationalization process started..." (Ailtom Barberino)

The same process is mentioned by Godinho (2011):

“The timing was not Marco's choice. The need for change came from pressure from outside Stefanini. After the opening of the technology market, Brazil was invaded by IT multinationals. Companies like IBM and EDA invested to win over customers in Brazil, just as they had in other countries..." (Godinho, 2011, p. 136).

After that, Stefanini initiated several operations in Latin America through the year 2000: Argentina, Chile, Peru, Colombia, Venezuela and Mexico. Except in the case of Argentina, where the entry was made through acquisition, all the other operations in the first wave were greenfield investments. The main objective of the first internationalization wave was for the company to become an international player. The second wave, which lasted from 2001 to 2003, occurred when Stefanini, having already established itself in Latin America, sought to enter a market considered "more daring" the United States.

"So, we were already preparing to fly higher: a major achievement, which was the big dream of establishing a position in the U.S. market. In 2001, I was already at Stefanini. That was when Marco [Stefanini] chose an executive, Antonio Moreira, to initiate the 
operation in the U.S. Antonio went there on a shoestring, but he was well supported by the company." (Ailtom Barberino).

The third wave started in 2003 and lasted until 2010. It was characterized by the entry into countries outside the Americas. Spain was the first European country that the company entered, along with Portugal. The main reason given for choosing these countries was the similarity of languages. Next came Italy and only then, England.

"I engineered our entry into England. I had been a customer of Mises, an English banking company, when I was CEO of Itaú in Europe. It was very interesting because Mises was in the process of hiring new suppliers. So, we started a new relationship there. Mises became a very important, strategic customer for Stefanini at that time. Consequently, we established an office in London to serve Mises. And from there, we continued with our expansion abroad." (Ailtom Barberino)

Also in Europe, the initial strategy was to carry out greenfield investments. It was to be based on a strategy of gaining positions with existing customers in those countries. Then, using those contacts, the company obtained references for new clients, thanks to its reputation with previous customers.

"We got some opportunities, some references, which is very important within a service segment. If you don't have any references for what you do, you're not going anywhere; you're not going to make it. The product is a little different. Why? Because the product meets technical standards, etc. that are already in the product's certification. It has to be adapted to the rules of that particular country. If the product meets the technical quality specifications, then there's the commercial question - whether it can compete in that market or not." (Ailtom Barberino).

In the case of the company's entry into Germany, the client companies had preferences that were very specific and distinct from those in other countries. Barberino explained:

"Germans don't like going offshore. German companies work with nearshore operations. Products with local or nearby support are okay to work with. But buying offshore doesn't work, except for a few platforms. For example, Deutsche Bank buys services from India. But what does it buy there? It buys developments in mainframe technology, platforms that they don't have in Europe. So, they import the service from those big systems platforms, but they end up having their own development centers there. They don't do anything long distance..." (Ailtom Barberino)

However, in Barberino's opinion, the sentiment about being a Brazilian company entering Germany was not as harsh as in the US: "It was different. Maybe a little veiled. But it was different. It was not so explicit as in the U.S. market." Barberino 
mentioned a meeting with a German company, where the client praised the cultural characteristic of Brazilian creativity:

"Marco Stefanini and I went to a meeting in Germany, in Berlin. And the client said: 'I want ground systems to be developed by Brazilians because you are very creative. You have a high degree of resolvability and we need to make the most of the space platform through ground solutions. We need you to come up with ideas to develop. For example, we have already created satellite-controlled pacemakers, warehouse solutions - stuff like that. But we want more; we need thousands of ground solutions to talk to the satellite and we have no idea what to do. We think that you Brazilians can come up with more ideas than we can.' It was the first time that we had heard a good compliment, but it was about something that was still a long way off. He was talking about a system that the company was going to develop some time in the future. Testing would begin in 2011, but we were talking in 2005 (laughs). For a Brazilian entrepreneur, that was unthinkable." (Ailton Barberino).

In 2006, Stefanini started preparing to go public. In addition to bringing in new resources for investment and growth, there was another reason to increase capital, which was "to increase customer confidence" (Godinho, 2011, p.180). Consequently, in November 2007 the company formally announced that the IPO would be launched in the second half of 2008. However, the year 2008 was marked by the global financial crisis, making the IPO impossible.

"The crisis totally changed the decision to go public. And we had designed a model where, after the IPO, we would start making acquisitions. How? We would make solutions acquisitions abroad that would increase our portfolio here in Brazil. And we would make acquisitions that would add volume in terms of customers, operations and international positions. The plan was very well designed and defined, based on the IPO. [...] Then, we held on to the plan. And then Marco made a personal reinvestment because Stefanini is a family company." (Ailtom Barberino)

Around 2010, when the Brazilian currency was strong against the U.S. dollar, Marco Stefanini decided to make a direct investment in the U.S. According to Godinho (2011, p.189):

"Marco Stefanini kept a fixed idea in mind: buy a company that would allow Stefanini to expand its operations in the U.S. and the world once and for all. This movement was nothing like what Marco had done in Stefanini's 22 years. Until then, the company had stayed on course, [...] without buying any competitor, but always via organic growth." (Godinho, 2011).

The first international acquisition in 2010 marked the beginning of Stefanini's fourth wave of internationalization. The company targeted for acquisition, TechTeam, had two divisions, one for private business and the other for business with the government. As a foreign company, it would be difficult for Stefanini to acquire the government division. However, months after negotiations started, another company 
acquired the government division, paving the way for Stefanini's acquisition of the other division. In November 2010, the purchase was finally approved by the TechTeam board

(Godinho, 2011). The company acquired all the shares held on the market and went private.

"We rebought all of TechTeam's capital and went private. We had a growth acceleration plan together with TechTeam and we were not going to have time to discuss it with a committee of shareholders. We literally needed to get our foot on the grass. Based on TechTeam's position and the references it had and its portfolio, it would be possible to cross sell at the base and leverage operations abroad." (Ailtom Barberino)

This acquisition was followed by others:

"We grew fast and continued to make acquisitions. From that point on, we made two more acquisitions in the U.S. And then we also expanded the U.S. operation there in 2010, 2011. We grew with two more acquisitions there, and after that there were several more acquisitions. [...] Since 2010, we have made 34 acquisitions, 26 of which are companies that we have put in a group called "Adventures." They are extremely advanced companies. Some of them were born in the startup movement and today they are part of a group that is highly specialized in digital transformation. They are part of an important group in this current scenario in which Stefanini is inserted, because the company strongly migrated from traditional services to digital services that could transform customer operations into digital operations and support innovation. Many of these acquisitions of innovative companies were in Brazil, and some were abroad. Today we have laboratories all over the world, in Romania, in the U.S., in Brazil, in Singapore, etc. The labs are all interconnected. They work in an innovation ecosystem where the creation of solutions ends up permeating all these fronts and adding more value and speed in the development of a new solution for our customers or a process of real transformation in that company. We are very well positioned and are growing a lot in that area." (Ailtom Barberino)

In 2012, in an interview with PIB magazine (2012), Marco Stefanini established

a growth target abroad for the company:

"I wanted $50 \%$ of our operations - maybe a little more - to be abroad. I intend to achieve that soon, perhaps in the next two years. Because internationalization also has its disadvantages, of course - everything in life comes with its pros and cons. The con, in this case, is the expenditure of energy and money. Normally, operations abroad have a lower margin than in Brazil. The pros? First, [internationalization] opens your mind; you get access to the best practices in the world. It also provides better capacity for planning and organization, quality certifications. Another point is that we open markets. The perspective I have of growing up in the U.S. is much bigger than here. In general, I would say that there are more pros than cons." (Marco Stefanini)

In 2012 the company's management was already envisioning digital transformation as a dominant paradigm and since then it had invested in new technologies, preparing the company for the future and for going public:

"But with the company already in a different status, a new activity involving the world of digital transformation, which is invaluable when you're talking about going public, because investors want to invest in companies that have an entrepreneurial spirit within 
this new context. We are already a stronghold in Industry 4.0. Today [2012], we are a reasonably diversified economic group, including fintechs. [...] So, the change we made has placed us on a different level of operations, including differentiated margins." (Ailtom Barberino)

In an interview in 2019 for the newspaper Correio Brasiliense (Cilo, 2019), Marco Stefanini, the company's Global CEO, stressed the importance of acquisitions for the digital transformation of the company:

"We have been in the process of acquiring tech companies and startups for almost 10 years. The goal is to strengthen our digital ecosystem. Currently, our group has almost 20 companies within that environment. [...] The focus is to buy companies that can add services to our portfolio so that we can offer what we call a 'full course' to the customer, with solutions capable of being integrated with other technologies offered by Stefanini. We have a lot of demand from sectors such as manufacturing, banking, retail, insurance, and pharmaceuticals, which need end to end solutions, that is, full services that require new products and solutions. [...] The main reason is the intense process of digital transformation that Brazil and the rest of the world have been going through. We have to position ourselves in that new environment." (Marco Stefanini)

Stefanini's IPO was originally planned for 2020, but was postponed to 2021 due to the Covid-19 pandemic. At the time of completion of the work, the IPO was planned to take place in New York - probably on the Nasdaq - and the company was working on an IPO plan.

In 2021, Stefanini's main international market was North America, encompassing the US and Canada. According to Barberino, the operation "already had a life of its own" and carried out its own acquisitions. In addition, Stefanini North America ran the Asia region:

"In terms of management and operation, Stefanini is divided into four regions. First, there's Brazil, which, due to the size of the operation, we treat as a region in itself. Then, there is the LATAM region, which includes all of Latin America, except Brazil. Then, there is North America (NA), which includes the US and Canada. And lastly, there is the EMEA region (Europe, Middle East and Africa). There is also an APAC (Asian Pacific) region, but it is subordinate to North America, meaning APAC is a North American initiative. All expansion in Asia has always been conducted via North America. So, practically speaking, Stefanini has five regions, but NA and APAC count as one. Each of them has a regional CEO and they all answer to the global CEO, Marco Stefanini." (Ailtom Barberino)

The second most important market so far in 2021 has been Latin America. In Europe, the countries of Eastern Europe have shown impressive growth due to the exports of products to the other European countries. These are called "near shore" suppliers, installed in the same region as the client countries. Within Eastern Europe, Romania has stood out, followed by Poland, Hungary, Moldova and Ukraine. Barberino 
noted: "From Eastern Europe we serve the rest of Europe because the costs are very attractive - both services and R\&D innovation laboratories and BPO services."

Stefanini's international trajectory reflects Marco Stefanini's profile, according to Carla Ferber, Head of Marketing at Stefanini North America:

"While at the same time you have the company's global personality and guidelines, the company is usually the reflection of the owner. The speed of growth comes from the owner's mentality ... [...] Stefanini's differential in the market reflects who Marco Stefanini is; he's informal; he's agile; he's flexible, and he has a very large sales force, which is aimed at the customer." (Carla Ferber)

\subsection{3 \\ Entry and operations in the United States}

Stefanini's entry into the US was a "dream" according to Barberino, but one that was very difficult to implement. Even so, in 2001 the company started its activities in there by establishing an office in Fort Lauderdale, Florida, which, according to Barberino, was a gateway for Latin companies, and Stefanini's executives believed that it would be easier to start business activities at that location. The office initially consisted of only the manager and a secretary. However, the endeavor proved to be more difficult than initially imagined:

"From the office in Fort Lauderdale, Florida, [Antonio Moreira] would have to cover the entire North American market. Before boarding a plane, the first obstacle to overcome would be to break through the barrier that exists for every Brazilian company: to be received in a simple meeting. Hence the question: What American or European would possibly associate the country of samba, soy, beer, beach, soccer and women in bikinis with methodical technology services? [...] At the time, no Brazilian tech company had attempted to explore developed markets in a structured manner. [...] For that reason, [...] in early 2001 Marco [Stefanini] and Antonio [Moreira] were definitely trailblazing. And, as always, the pains of trailblazing are enormous. Not only was the Brazil brand weak in the sector, but there was no customer to use as a reference. [...] The next few months would drag on. A lot of attempts; few results." (Godinho, 2011, p. 155).

Global Vice President Ailtom Barberino realized that the company suffered a lack of knowledge at the time about the practices of American companies, which he called a "reading error":

"We didn't have recognition from the U.S. market regarding what we could do, what we could deliver. We depended a lot on offshore development, and we didn't have local delivery. I think there was a reading error because we wanted to deliver to the U.S. from Latin America. But the U.S. market did not think Latin America was mature enough to deliver to the U.S. So, it wasn't buying from Latin America. But - yes - the U.S. was buying from Mexico... only that these services were performed in Mexico by American 
companies. [...] The Mexican operation was able to serve the U.S. well because the Americans operated the platform, not the Mexicans. [...] The main exposure of the U.S. in terms of services was with India, in addition to Mexico. [...] And that was for us a costly mistake because it meant years of trying to establish an operation without succeeding." (Ailtom Barberino)

An external event, the September 11, 2001 terrorist attack, made the process even more difficult, as the uncertainty it produced had a cautioning effect among U.S. companies, which would rather go with the usual suppliers than try new suppliers:

"...more than a year had passed since we opened the office in the U.S., and Antonio [Moreira] was facing a strong tide against the market. [...] A lot of phone calls, a lot of plane trips, a lot of time spent, but very few results. A few contracts were signed, but nothing important: in general, small, peripheral and unprofitable services." (Godinho, 2011, p.159)

There was clearly a credibility barrier when it came to technology products from Latin America. That barrier became clear to Barberino in a conversation with a CEO:

"He [the CEO] said to me: 'Ailtom, do you know why you're not growing here?' I said 'no.' 'Because you don't have a showcase here.' [...] We didn't have an example to offer: a reference from a local American company that used the services of a Latin company. I think that his analysis was right on, because that was it. You don't have a reference from anyone really big who uses something you have done; something that can be your benchmark. Yes, I think that was a big problem, a real barrier." (Ailtom Barberino)

Even the clients that Stefanini was already serving in Brazil, such as Johnson \& Johnson, did not purchase their services in the U.S.

"The interesting thing is that at the beginning we hoped to have the support of those customers that we had developed and that could help us by opening doors in other countries. Mainly parent companies that had subsidiaries in Brazil. Our first customer at Stefanini was Johnson \& Johnson. J\&J is a 32-year contract customer and we thought they would be able to open a door for us there in the U.S. But that didn't happen. We were unable to win the American J\&J, even though we did provide quality services here in Brazil. Johnson did open the door for us in Mexico, but not in the U.S. And that was the case with several other American companies, which we already served here in Brazil. But we achieved nothing from it. The first company that was our client, which opened a door for us in the U.S., was Clorox, an American company with local operations in California. Clorox gave us an opportunity. It was the first." (Ailtom Barberino)

Communication also emerged as a barrier for the company due to the lack of fluency of Stefanini executives and technicians in English. Even those who spoke the language well did not have the desired fluency, particularly when it came to the technical language necessary for the development of IT projects. In addition to the language barrier, there were cultural differences, as explained by Carla Ferber, Head of 
"I'll give you an example. We moved to an open office. Only the meeting room was closed. So, sometimes someone is talking to someone else and a third person is listening. [...] The Brazilian automatically looks over the top of the screen and gives an opinion. For the American, it's disrespectful to listen to someone else's conversation, to meddle. Interrupting someone to speak is a lack of respect; it's the last straw. That kind of informality is more Brazilian, a more Brazilian style of working." (Carla Ferber)

In 2002, Stefanini obtained a significant contract with Kimberly-Clark in the U.S., prompting the company to open an office in Atlanta to serve that client. After that, although slowly, the American branch managed to close other contracts and "establish references for Stefanini in the United States" (Godinho, 2011, p.163). Nonetheless, the company suffered strong competition from the Indians, who competed on the basis of prices and were advancing in terms of quality and training. Thus, in 2002 Stefanini obtained the CMM (Capability Maturity Model) certification already used by Indian software companies and which was considered necessary to compete in the North American market.

According to Barberino, the operation only started to generate more revenue when Stefanini was finally able to initiate the first offshore project for an American company from Iowa. Stefanini developed an offshore platform for that client in Brazil, in Minas Gerais, with a team dedicated exclusively to the project. Stefanini had to send the team to the U.S. to live in the city where the company was located. The team spoke English well. Consequently, the arrangement worked. It had taken some time for the company to finally realize that it was necessary to have an advanced team with a good grasp of the language.

For Barberino, being a Brazilian company entering the American market is a disadvantage due to the stereotypes of Brazil and Brazilians abroad:

"If we were Germans looking to open a new market, we would have a better chance; I think the conversation would be different. If an American were to hire a German, he would know the German is disciplined; he would know that he will stay focused; he would know the qualities of the German people. But the American would not see the Brazilian like that. And that's where we had a problem. And I think that, right now, that problem is being exported again all over the world, in that our control of Covid-19 is a wreck. So this is how an American sees us: 'Brazilians are a nice people, but they need discipline, focus. I need things that I don't think Brazilians have.' It's a matter of maturity. And then there's the language barrier, like when I put the American project manager to talk to the team in Brazil. And there's also the issue of discipline, which they think we don't have. Adding up all those attributes, it's a disadvantage. We [Brazilians] do not have a good image of those who work well, work hard, who are focused, who produce. [...] So, they think we don't have good productivity, that we have a project management problem, a decision problem. Things like that are not a good package deal, are they? First, you have to try to sell. We usually say - and it's a fact - that for you to position yourself in a country, you have to sell your country first. Second, you need to 
convince the buyer that you can develop and deliver with quality. And finally, you have to convince them that you can be a long-term player, that you will be resilient, and that you will be able to keep on with that company. You have to convince the person three times: you have to sell your country, sell your company, your brand, and then sell credibility as to continuity."

With the acquisition of TechTeam in 2010, all that changed. TechTeam already had 3,000 employees in the United States, and the availability of that local group made all the difference for Stefanini. In addition, at the time of the acquisition by Stefanini, TechTeam was present in 17 countries and had a very strong presence in the U.S. With Stefanini already operating in 18 countries, the acquisition led the company to be present in 23 countries. As confirmed by the company's management, the TechTeam acquisition provided Stefanini with rapid international growth. Stefanini had already thought about entering the Chinese market, but it did not succeed until 2010. TechTeam was strong in Europe and Asia, and it was present in locations where the company would like to be present.

"In 2010, TechTeam already had positions in Europe, with offices in Belgium (TechTeam's headquarters are in Belgium). It was already in Belgium, and wellpositioned in Germany, Denmark, Switzerland, Sweden, France, and in many other countries, including Romania itself. The operation in Romania was actually a TechTeam acquisition, so that propelled growth in Eastern Europe. When we acquired TechTeam, we gained a market that we didn't have before. And we also added a volume to our European operation that we had not yet achieved. TechTeam had done a great job of expansion in Europe and we bought that operation. As a result, we grew quickly in Europe and started to experience organic growth within the operation that TechTeam had created, using our own portfolio of services and products." (Ailtom Barberino)

TechTeam was located in Southfield, in the metropolitan area of Detroit, where the North American auto industry was concentrated. It was a region that was experiencing a period of decline. The company had suffered from the problems of the local industry, which motivated its sale. In an interview with Revista PIB (2012), Marco Stefanini explained the initial difficulties:

"In the case of TechTeam, the results were not all that bad. It had three straight years of reduced revenue and losses. This year [2012], it will make a small profit and it will grow; i.e. it has already changed. But it still doesn't look like Stefanini. That is my biggest challenge for the years to come. I would say that our success abroad is partial, precisely because we still need to work harder on the issue of culture. One way to do that is to appoint a Stefanini person to direct the units abroad and to instill the culture of working hard and producing a lot." (Marco Stefanini)

Carla Ferber (Head of Marketing North America) explained that TechTeam was a company with a more traditional culture. It was not based in a large capital, but in a 
smaller city. Thus, the profile of the executives was quite different from what it would be in a large metropolis such as New York or Chicago.

"When I arrived here, there was a feeling of being accepting of the local culture, but also adding a little bit of the Stefanini way of being, of working. Today it has changed completely; the Stefanini way of doing business permeates it a bit more, with respect to the local norms. But in the beginning, it was an American company that had been bought by a Latin, Brazilian company, and there was some embarrassment because of it. I started with two other Brazilians. Today we have a large mix, including Latins and women... Stefanini's diversity..." (Carla Ferber)

Ferber explained how the company positions itself when presenting itself in order to overcome the barriers of being a Brazilian company in the U.S.:

"[The company] does not position itself as a Brazilian multinational; it emphasizes its capabilities. If a customer is a multinational with a very strong presence in North and South America, then I'm interested in playing the Latin card. If it doesn't matter, we don't introduce ourselves like that. When you enter our website or any positioning matter or with the sales team, we don't present ourselves as a Brazilian multinational. Five years ago, when we would talk about Brazil, people would think of soccer, carnival, naked women and beer - not technology. For you to prove yourself for outsourcing, you have to be able to offer the cheapest labor, which is how we got here. Today the company wants to be a digital player, so it has to take the stigma out of cheap Latin labor and show capabilities, efficiency, innovation." (Carla Ferber).

\subsection{4 \\ Institutions in Brazil}

Marco Stefanini, founder and Global CEO of Stefanini IT, in an interview with UOL Economia (2018), summarizes the difficulties a Brazilian tech company faces when trying to have credibility abroad, and how that would imply the need to present itself as a multinational, and not as a Brazilian company:

"There are no big advantages in being a Latin tech company. Unfortunately, Brazil is still not known as a tech country worldwide. From a brand point of view, it adds nothing. At least Brazil is a neutral country. It's a very nice country from the flesh-and-blood point of view, but from the business point of view, it is pretty much ignored; it is not yet associated with business very much. [...] We have an origin, which is Brazilian, and obviously we are proud to be Brazilians, but the fact of the matter is that we have to highlight ourselves as being a global company, with deliveries distributed all over the world ...." (Marco Stefanini)

Barberino stated that Stefanini has already made efforts to convince associations and the government to seek to build a more favorable image for Brazilian technology companies:

"We fought a lot within the association and even with the government; we argued a lot; we fought a lot about the issue. We would say: Stop selling Brazil abroad as carnival, 
soccer, happiness and fun. That is not what customers want to hear when they contract for a service. When they contract a project, they don't want to know about carnival, soccer or happiness; they want to know about seriousness, commitment, quality. That's what they want to find out." (Ailtom Barberino)

However, for Barberino, some Brazilian institutions were and are important for the expansion of the international performance of Brazilian companies. He cited Apex (Brazilian Trade and Investment Promotion Agency) in particular:

"I think that the one who did the best job, who did his homework - I always say that was Minister Furlan, because he created Apex. He had the smarts to create an agency that focused on exporting products and services from Brazil. That agency's mission was to showcase what Brazil was doing. So, it held several summits and put on events abroad, showing off Brazilian products, showing off Embraer and Petrobras (which, despite its problems, developed a large oil production platform), showcasing the technology of our agriculture, based on Embrapa. Also, it started to show that Brazil had laboratories, had scientists to develop ideas, to develop projects, and that it also had the capacity to develop products with global quality. That helped a lot. But we still haven't won..." (Ailtom Barberino)

Barberino also highlighted other aspects in the Brazilian environment that hinder internationalization. First, Brazilian institutions do not encourage Brazilian companies to internationalize via direct investment abroad:

"We don't have that incentive. That is something that we strive for a lot because Marco is also the president of FET, which is the Forum of Transnational Companies, and this is something that we discuss a lot. There's no incentive in Brazil today for any international expansion of services, of service companies. There are incentives for product exporters, but none for internationalization, unlike a lot of countries that really encourage the development of companies abroad. We still don't have a program to help us do that." (Ailtom Barberino)

Furthermore, Barberino mentioned how Brazil's high level of taxation and bureaucracy hinder even the creation of new companies:

"Brazil is the only country in the world where the entrepreneur pays taxes before even starting to operate. These things need a thorough review and course correction. Just because you created a company, a legal entity, you already have to pay taxes and set-up fees for your company; you have to pay every year; you have to collect other annual fees that have to do with the existence of your company, without generating one [Brazilian] real. So, it doesn't work. Startups really suffer here! " (Ailtom Barberino)

In an interview with UOL Economia (2018), Marco Stefanini highlighted other aspects that make it difficult for a Brazilian company to do business:

"As a society, as a country, Brazil still does not see the great opportunities and threats that the tech movement holds. If you look at the leadership of most countries, the discourse is much more up-to-date. Brazil not only does not support the changes, but the discourse is also weak.... [...] In fact, it's the opposite [of other nations]. [...] The direction is far below that of other countries. We are falling behind." (Marco Stefanini) 
"Today [2018], I would say that the level of pressure that we suffer from costs is much higher here in Brazil. This represents a higher turnover of contracts. Currently, of the 40 countries in which Stefanini operates, [Brazil] is certainly one of the most difficult countries to operate in. There is a second point, which is the unfavorable economic environment.... [...] Brazil is going through a period of three years of crisis, but from the IT point of view, it's been longer - at least five years, during which we have been under considerable pressure due to cost and competitiveness issues. [...] In fact, Brazil today, due to the result of the crises, is much more difficult to work with than the global [market]. The matter of price, competition, the power in the area of purchasing is much greater here in Brazil than abroad." (Marco Stefanini)

In another interview, published in Correio Brasiliense (Cilo, 2019), Stefanini was even more emphatic when he stated that, "without reforms, Brazil is economically unviable."

\section{6 \\ Discussion}

The internationalization of Stefanini IT Solutions can be divided in four "waves", or stages, which can be clearly differentiated considering regions and countries entered, entry modes used, and the strategic issues behind these moves (Table 10).

Table 10 - Stages in Stefanini's Internationalization Process

\begin{tabular}{|l|l|l|l|}
\hline Stage & $\begin{array}{l}\text { Countries/ } \\
\text { Region }\end{array}$ & Entry Mode & Strategic Issues \\
\hline $\begin{array}{l}1 . \\
1996-\end{array}$ & Latin America & $\begin{array}{l}\text { Acquisition } \\
\text { (Argentina) } \\
\text { Greenfield } \\
\text { (others) }\end{array}$ & $\begin{array}{l}\text { - Defensive strategy } \\
\text { - Risk diversification } \\
\text { - To become an international player }\end{array}$ \\
\hline $\begin{array}{l}2 . \\
2001- \\
2003\end{array}$ & U.S. & Greenfield & $\begin{array}{l}\text { - Presence in a key international market } \\
\text { - Organic growth }\end{array}$ \\
\hline $\begin{array}{l}3 . \\
2003- \\
2010\end{array}$ & $\begin{array}{l}\text { Europe and other } \\
\text { countries outside } \\
\text { the Americas }\end{array}$ & Greenfield & $\begin{array}{l}\text { - Expansion beyond the Americas } \\
\text { - Network development in foreign markets } \\
\text { - Organic growth }\end{array}$ \\
\hline $\begin{array}{l}\text { World } \\
2020-\end{array}$ & $\begin{array}{l}\text { Acquisitions } \\
\text { and } \\
\text { ventures }\end{array}$ & $\begin{array}{l}\text { - Rapid international expansion } \\
\text { - Fast corporate growth } \\
\text { - To become a global player } \\
\text { - Diversification of the firm's portfolio } \\
\text { - Acquisition of innovative firms in in } \\
\text { digital transformation segment } \\
\text { - Access to world-class practices }\end{array}$ \\
\hline
\end{tabular}


Internationalization only happened ten years after the company's inception, and can be characterized as a defensive move to diversy risks, but also aiming at upgrading from a purely domestic operation to an international firm. Such change was deemed necessary to face the competition of global players, and it coincided with the deregulation of the domestic IT industry (Da Rocha, Moraes \& Mello, 2019). The first move was the acquisition of a small company in Argentina, followed by a series of greenfield investments in other Latin American countries. The second stage was characterized by entering in a strategically relevant market for the IT industry, the U.S. The entry mode chosen was an office in Florida, because of the cultural proximity with Latin America (O'Grady \& Lane, 1996). Later the company opened other offices in the U.S. The third wave marked the entry of the firm in Europe and other countries outside the Americas. The mode of entry was always greenfield investments, first to culturallyclose countries and then to countries more culturally distant. The fourth wave is marked by expansion through acquisitions and joint ventures. The first, and sizeable, acquisition was the U.S. IT firm TechTeam. This move meant a substantial jump in corporate size (the acquired firm had 3,000 employees), as well as the acquisition of a portfolio of products, clients, and positions in foreign markets. The acquisition turned Stefanini into a global player, with subsidiaries, offices and laboratories in several countries and continents. From there on, the company continued to embark in several acquisitions in Brazil and in foreign countries. In addition, global expansion was accelerated as the acquired companies expanded their international reach by means of organic growth.

The entry in the U.S. and subsequent acquisitions were decisive to Stefanini's internationalization process, because this acquisition was the one that changed the nature and status of the firm, from a Brazilian or Latin American firm, to a truly global one. Yet this entry was by no means easy, according to the interviews and secondary data sources. The issues and corresponding liabilities faced by Stefanini in the U.S can be divided according to the three liabilities: foreigness, emergingness and outsidership (Table 11).

Table 11 - Issues and corresponding liabilities faced by Stefanini in the U.S.

\begin{tabular}{|l|l|l|}
\hline $\begin{array}{l}\text { Type of } \\
\text { Liability }\end{array}$ & Issues & Selected excerpts of interviews \\
\hline $\begin{array}{l}\text { Liability of } \\
\text { Foreignness }\end{array}$ & $\begin{array}{l}\text { Company and brand } \\
\text { unknown in the U.S. }\end{array}$ & $\begin{array}{l}\text { "We didn't have recognition from the U.S. market } \\
\text { regarding what we could do, what we could deliver." } \\
\text { "We did not have a recognition from the North } \\
\text { American market regarding what we could do, what }\end{array}$ \\
\hline
\end{tabular}




\begin{tabular}{|c|c|c|}
\hline & & $\begin{array}{l}\text { we could deliver. We were very dependent on } \\
\text { offshore development." }\end{array}$ \\
\hline & $\begin{array}{l}\text { Lack of knowledge } \\
\text { in the U.S. of the } \\
\text { Brazilian IT industry }\end{array}$ & $\begin{array}{l}\text { "At the time, no Brazilian tech company had } \\
\text { attempted to explore developed markets in a } \\
\text { structured manner." }\end{array}$ \\
\hline & $\begin{array}{l}\text { Lack of knowledge } \\
\text { of local practices }\end{array}$ & $\begin{array}{l}\text { "...a costly mistake because it meant years of trying } \\
\text { to establish an operation without succeeding." }\end{array}$ \\
\hline & $\begin{array}{l}\text { Lack of fluency in } \\
\text { the local language }\end{array}$ & $\begin{array}{l}\text { "And then there's the language barrier, like when I } \\
\text { put the American project manager to talk to the team } \\
\text { in Brazil." }\end{array}$ \\
\hline & $\begin{array}{ll}\text { Lack } & \text { of } \\
\text { understanding } & \text { of } \\
\text { cultural differences }\end{array}$ & $\begin{array}{l}\text { "For the American, it's disrespectful to listen to } \\
\text { someone else's conversation, to meddle. [...] That } \\
\text { kind of informality is }[\ldots] \text { a more Brazilian style of } \\
\text { working." }\end{array}$ \\
\hline & Lack of credibility & $\begin{array}{l}\text { "We can be competitive in terms of costs, but we } \\
\text { have not yet managed to win the trust of the United } \\
\text { States." }\end{array}$ \\
\hline $\begin{array}{lr}\text { Liability of } \\
\text { Emergingness }\end{array}$ & $\begin{array}{l}\text { Inconsistent country } \\
\text { image }\end{array}$ & $\begin{array}{l}\text { "What American or European would possibly } \\
\text { associate the country of samba, soy, beer, beach, } \\
\text { soccer and women in bikinis with methodical } \\
\text { technology services?" } \\
\text { "... when we would talk about Brazil, people would } \\
\text { think of soccer, carnival, naked women and beer - } \\
\text { not technology." } \\
\text { "Unfortunately, Brazil is still not known as a tech } \\
\text { country worldwide. From a brand point of view, it } \\
\text { [the country name] adds nothing." }\end{array}$ \\
\hline & $\begin{array}{l}\text { Inconsistent region } \\
\text { (Latin } \\
\text { image }\end{array}$ & $\begin{array}{l}\text { "...the U.S. market did not think Latin America was } \\
\text { mature enough to deliver to the U.S." } \\
\text { "They didn't buy it because they didn't believe that } \\
\text { Latinos could offer quality service development." }\end{array}$ \\
\hline & $\begin{array}{l}\text { Negative country } \\
\text { image }\end{array}$ & $\begin{array}{l}\text { "And I think that, right now, that problem is being } \\
\text { exported again all over the world, in that our control } \\
\text { of Covid-19 is a wreck." }\end{array}$ \\
\hline & $\begin{array}{l}\text { Lack of credibility } \\
\text { associated to national } \\
\text { stereotypes }\end{array}$ & $\begin{array}{l}\text { "If we were Germans looking to open a new market, } \\
\text { we would have a better chance." } \\
\text { "[...] this is how an American sees us: 'Brazilians are } \\
\text { a nice people, but they need discipline, focus. I need } \\
\text { things that I don't think Brazilians have.' }\end{array}$ \\
\hline & $\begin{array}{l}\text { Lack of home } \\
\text { country support to } \\
\text { internationalization }\end{array}$ & $\begin{array}{l}\text { "There's no incentive in Brazil today for any } \\
\text { international expansion of services, of service } \\
\text { companies." }\end{array}$ \\
\hline & $\begin{array}{l}\text { Lack of home } \\
\text { country investment } \\
\text { in developing a } \\
\text { favorable country } \\
\text { image }\end{array}$ & $\begin{array}{l}\text { "We fought a lot within the association and even with } \\
\text { the government }[\ldots] \text {. We would say: Stop selling } \\
\text { Brazil abroad as carnival, soccer, happiness and fun. } \\
\text { That is not what customers want to hear when they } \\
\text { contract for a service. [...] they want to know about } \\
\text { seriousness, commitment, quality." }\end{array}$ \\
\hline $\begin{array}{l}\text { Liability of } \\
\text { Outsidership }\end{array}$ & $\begin{array}{l}\text { Lack of local } \\
\text { contacts }\end{array}$ & $\begin{array}{l}\text { "...the barrier that exists for every Brazilian } \\
\text { company: to be received in a simple meeting." }\end{array}$ \\
\hline & Lack of referrals & $\begin{array}{l}\text { "We didn't have an example to offer: a reference } \\
\text { from a local American company..." } \\
\text { "[...] there was no customer to use as a reference." }\end{array}$ \\
\hline
\end{tabular}




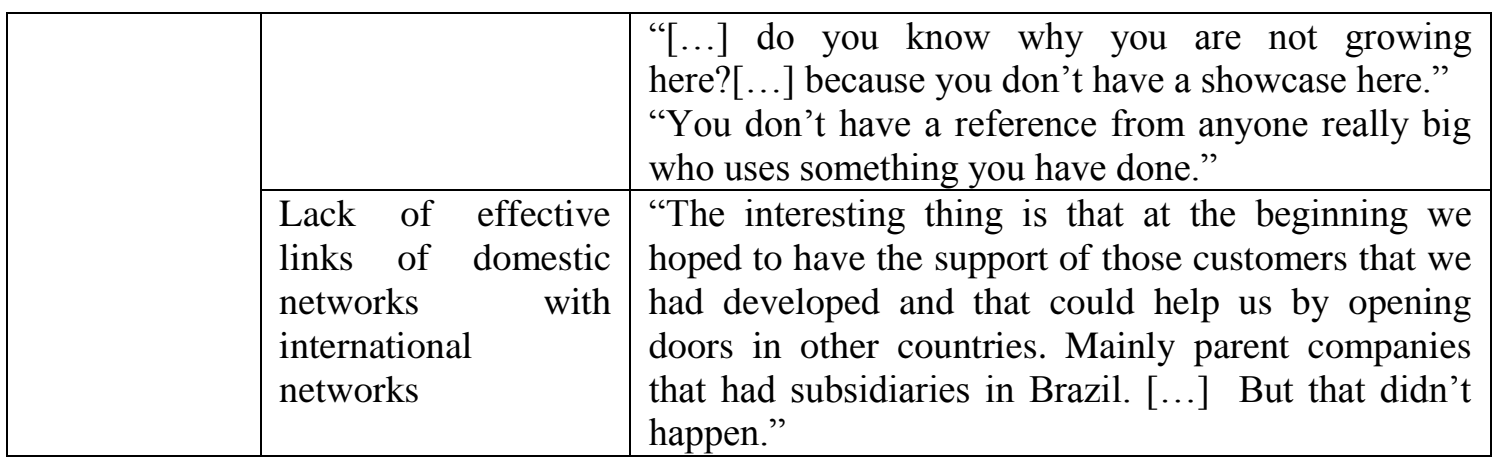

In the first block, concerning the issues related to the liability of foreignness, most problems perceived by the firm's executives are organization-related (lack of knowledge of local practices and cultural differences, lack of language skills etc.) and only one problem is environmental-related (lack of awareness in the U.S. market of the Brazilian IT industry) (Gaur, Kumar \& Sarathy, 2011). The issues related to the liability of emergingness, as perceived by the firm's executives are mainly environment-related (such as inconsistent or negative country and region image, and inadequate national stereotypes) and government-related (lack of home country support to firm internationalization and lack of investments in developing a favorable country image) (Zhou, 2018). Finally, all issues raised relative to the liability of outsidership are organization-related (lack of local contacts, of referrals, and of linkages between home and host country networks). All of them refer to not belonging to international networks which are deemed critically important to the success of the firm's internationalization (Johanson \& Vahlne, 2009). Of all this issues, by far the ones perceived as most difficult to overcome were the environment-related issues affecting the liability of emergingness and the issues related to liabilities of outsidership.

Having faced all these issues to establish a meaningful position in the U.S. market, Stefanini's management employed several strategies to gain legitimacy to operate in the U.S., and, as a consequence, to become a truly global player. Table 12 presents the strategies employed during the four stages of internationalization with a presence in the U.S.

Table 12 - Strategies for legitimation employed by Stefanini in the U.S. according to the stages of firm internationalization

\begin{tabular}{|c|c|c|}
\hline Stage & Strategies & Results \\
\hline $\begin{array}{l}1 \\
1996-2000\end{array}$ & (No operations in the U.S.) & \\
\hline $\begin{array}{l}2 \\
2001-2003\end{array}$ & $\begin{array}{l}\text { - Establish a local office } \\
\text { - Efforts to develop a local network (meetings, }\end{array}$ & First contracts \\
\hline
\end{tabular}




\begin{tabular}{|l|l|l|}
\hline & contacts, etc.) & \\
\hline 3 & $\begin{array}{l}\text { - Efforts to generate good referrals } \\
\text { - New offices in the U.S. }\end{array}$ & Slow organic growth \\
\hline 4 & $\begin{array}{l}\text { - Acquisition of a relatively large local company with } \\
\text { operations several countries } \\
\text { - Use of the network of the acquired firms to establish } \\
\text { the parent company in other host markets } \\
\text { - Presenting the company a global player (neither } \\
\text { Brazilian nor Latin American) }\end{array}$ & $\begin{array}{l}\text { Fast international } \\
\text { growth }\end{array}$ \\
\hline
\end{tabular}

In the first stage of internationalization, the firm had no operations in the U.S. Only in the second stage it opened an office in Florida. However, the first movements were very timid, and required very limited resources. Yet the firm was slowly acquiring knowledge on the new institutional environment, including business practices and the negative impact of liabilities of emergingness and outsidership. As a result, during the second and the third period, the U.S. operation grew very slowly. The leap occurred when the firm made a large acquisition of a U.S. company that had operation in several countries. The decision to expand through acquisition allowed the firm to participate in the already established networks of the acquired firms, thus overcoming the liability of outsidership. This strategy helped the firm to achieve the desired referrals and recognition. In particular, this move permitted the firm to present itself as a U.S,. company, and not as a Brazilian or Latin-American company. As pointed out by one of the interviewees, "for you to position yourself in a country, you have to sell your country first." And with the image of Brazil being completely disconnected from technology, the solution envisaged for the company to succeed globally was not to associate the Company/brand image to the country image (although not denying it), as explicitly indicated by the company's founder.

Thus, legitimation by acquisition of a local company in the host market addressed the three liabilities: of foreigness, by acquiring knowledge on all aspects of the institutional environment of the host country; of emergingness, by detaching the company image from its national origins; and of outsidership, due to the already established connections of the acquired companies in the host market and in other international markets. Therefore, the process of gaining legitimacy in a developed host market by the Brazilian firm addressed mostly the cultural-cognitive and the pragmatic dimensions of legitimacy (Zhang et al., 2020), where the problems resided. This was achieved by means of an isomorphic strategy, by which the firm attached to its company 
image the attributes and image of a local company, in order to gain acceptance in the host market, contrary to Kostova, Roth and Dacin's (2008) arguments.

\section{7 \\ Final Remarks}

This study examined how an entrepreneurial firm from an emerging market overcomes national institutional voids by expanding internationally, particularly to countries of high institutional quality, and examines the liabilities faced by the firm and how it employs specific legitimation practices to develop its cross-border activities. The contributions of the study are an in-depth examination of the barriers associated to the three types of liabilities - foreignness, emergingness and outsidership - to the successful entry and operation of a high-tech firm from an emerging country in a developed market, identifying the nature of these barriers, and the firm responses along its internationalization process to overcome these liabilities and gain legitimacy in the foreign market. The study presents relevant contributions for other emerging market firms, from the same and also from other segments, in showing how an emerging market firm uses legitimacy strategies to gain space and conquer reliability in host markets in high institutional contexts. This study is also relevant and helps government agencies that support the internationalization of emerging market firms to focus on the gaps and opportunities, such as financial support as well as working on the brand image of the country in foreign markets.

As to the limitations of the study, in addition to those related to the research method used, the case study, the interviews were conducted with only two top executives, but both placed in strategic positions in the firm. In addition, the use of a large amount of secondary data, including interviews with the company founder and CEO in several business magazines and newspapers, as well as a biographical book, and several other sources provided a wealth of data that allowed to overcome the limitations in terms of number of interviews.

The study offers several opportunities for further research. Smaller-sized entrepreneurial firms (Keupp \& Gassmann, 2009), and firms from other segments could be units of analysis to understand how firms from emerging economies overcome the liabilities of foreigness, emergingness and outsidership. Also a quantitative study with entrepreneurial high-tech firms originating from countries whose country image is not 
favorable to technology should provide the opportunity to test whether the legitimation strategies adopted are similar and identify new patterns. More country image studies associated to the acquisition of firms in advanced countries by firms from emerging economies should also help to improve our understanding of this issue.

\section{8 \\ References}

Abdi, M., \& Aulakh, P. (2012). Do country-level institutional frameworks and interfirm governance arrangements substitute or complement in international business relationships?. Journal of International Business Studies, 43, 477-497.

Aldrich, H. E., \& Fiol, C. M. (1994). Fools rush in? The institutional context of industry creation. Academy of management review, 19(4), 645-670.

ABES (2020). Brazilian Software Market: Scenario and Trends, 2020. São

Paulo: Associação Brasileira das Empresas de Software. Available at: https://abessoftware.com.br/wp-content/uploads/2020/10/ABES-

EstudoMercadoBrasileirodeSoftware2020.pdf

Acemoglu, D., Johnson, S., \& Robinson, J. A. (2001). The colonial origins of comparative development: An empirical investigation. American Economic Review, 91(5), 1369-1401.

Adomako, S., Amankwah-Amoah, J., Dankwah, G. O., Danso, A., \& Donbesuur, F. (2019). Institutional voids, international learning effort and internationalization of emerging market new ventures. Journal of International Management, 25(4), 100666.

Audretsch, D., \& Caiazza, R. (2016). Technology transfer and entrepreneurship: cross-national analysis. The Journal of Technology Transfer, 41(6), 1247-1259.

Bendickson, J. S., Irwin, J. G., Cowden, B. J., \& McDowell, W. C. (2020). Entrepreneurial ecosystem knowledge spillover in the face of institutional voids: groups, issues, and actions. Knowledge Management Research \& Practice, 19(1), 117 126.

Bowen, H. P., \& De Clercq, D. (2008). Institutional context and the allocation of entrepreneurial effort. Journal of International Business Studies, 39(4), 747-767. 
Bruton, G. D., Lau, C. M., \& Obloj, K. (2014). Institutions, resources and firm strategies: a comparative analysis of entrepreneurial firms in three transitional economies. European Journal of International Management, 8(6), 697-720.

Chen, J., Saarenketo, S., \& Puumalainen, K. (2016). Internationalization and value orientation of entrepreneurial ventures - a Latin American perspective. Journal of International Entrepreneurship, 14(1), 32-51.

Cheng, H. L., \& Yu, C. M. J. (2008). Institutional pressures and initiation of internationalization: Evidence from Taiwanese small and medium-sized enterprises. International Business Review, 17(3), 331-348.

CNN Brasil (2020). CNN Brasil Business - Stefanini cresce $20 \%$ na pandemia e enxerga o IPO cada vez mais próximo. Available at: https://www.cnnbrasil.com.br/business/2021/01/22/stefanini-cresce-20-na-pandemia-eenxerga-o-ipo-cada-vez-mais-proximo

Correio Braziliense (2019). Correio Braziliense. Sem as reformas, o Brasil é economicamente inviável. Available at: https://www.correiobraziliense.com.br/app/noticia/economia/2019/02/14/internas_econ omia,737452/entrevista-com-marco-stefanini.shtml

Da Rocha, A., Moraes, S.T.A., \& De Mello, R. C. (2020). Entrepreneurial behavior of mature firms in internationalization: evidence from a high-tech industry. Base Revista de Administração e Contabilidade da Unisinos, 16(4), 523-551.

Danis, W. M., Chiaburu, D. S., \& Lyles, M. A. (2010). The impact of managerial networking intensity and market-based strategies on firm growth during institutional upheaval: A study of small and medium-sized enterprises in a transition economy. Journal of International Business Studies, 41(2), 287-307.

Deng, Z., \& Sinkovics, R. R. (2018). Rapid expansion of international new ventures across institutional distance. Journal of International Business Studies, 49(8), 1010-1032.

Elg, U., Ghauri, P. N., Child, J., \& Collinson, S. (2017). MNE microfoundations and routines for building a legitimate ansd sustainable position in emerging markets. Journal of Organizational Behvior, 38(9), 1320-1337.

Eisenhardt, K. M. (1989). Building theories from case study research. The Academy of Management Review, 14(4), 532-550.

Escandon-Barbosa, D., Urbano-Pulido, D., \& Hurtado-Ayala, A. (2019). Exploring the relationship between formal and informal institutions, social capital, and 
entrepreneurial activity in developing and developed countries. Sustainability, 11(2), 550.

Gammeltoft, P., Pradhan, J.P., \& Goldstein, A. (2010). Emerging multinationals: home and host country determinants and outcomes. International Journal of Emerging Markets, 5(3/4), 254-265.

Gaur, A. S., Kumar, V., \& Sarathy, R. (2011). Liability of foreignness and internationalisation of emerging market firms. In Dynamics of globalization: Locationspecific advantages or liabilities of foreignness?. (p.211-233). Bingley: Emerald.

García-Cabrera, A. M., García-Soto, M. G., \& Durán-Herrera, J. J. (2016). Opportunity motivation and SME internationalisation in emerging countries: Evidence from entrepreneurs' perception of institutions. International Entrepreneurship and Management Journal, 12(3), 879-910.

Ghauri, P. (2004). Designing and conducting case studies in international business research. In Marschan-Piekkari, R., \& Welch, C. (Eds.). Handbook of Qualitative Research Methods in International Business (p.109-124). Cheltenham, UK: Edward Elgar.

Godinho, R (2011). O Filho da Crise. São Paulo: Matrix.

Han, X., Liu, X., Xia, T., \& Gao, L. (2018). Home-country government support, interstate relations and the subsidiary performance of emerging market multinational enterprises. Journal of Business Research, 93, 160-172.

Hobdari, B., Gammeltoft, P., Li, J., \& Meyer, K. (2017). The home country of the MNE: The case of emerging economy firms. Asia Pacific Journal of Management, $34,1-17$.

Johanson, J., \& Vahlne, J. E. (2009). The Uppsala internationalization process model revisited: From liability of foreignness to liability of outsidership. Journal of International Business Studies, 40(9), 1411-1431.

Khanna, T., \& Palepu, K. (1997). Why focused strategies may be wrong for emerging markets. Harvard Business Review, 75(4): 41-51.

Khanna, T., Palepu, K. G., \& Sinha, J. (2005). Strategies that fit emerging markets. Harvard Business Review, June, 2-18.

Kiss, A. N., \& Danis, W. M. (2008). Country institutional context, social networks, and new venture internationalization speed.European Management Journal, 26(6), 388-399. 
Kiss, A. N., \& Danis, W. M. (2010). Social networks and speed of new venture internationalization during institutional transition: A conceptual model. Journal of International Entrepreneurship, 8(3), 273-287.

Kostova, T., \& Marano, V. (2019). Institutional theory perspectives on emerging markets. In: Grosse, R., \& Meyer, K. E. (eds.) The Oxford Handbook of Management in Emerging Markets. (pp. 99-126). New York: Oxford University Press.

Kostova, T., Roth, K., \& Dacin, M.T. (2008). Institutional theory in the study of multinational corporations: a critique and new directions. Academy of Management Review, 33(4), 994-1006.

Liu, Y., \& Yu, Y. (2018). Institutions, firm resources and the foreign establishment mode choices of Chinese firms: The moderating role of home regional institutional development. Journal of Business Research, 93, 111-121.

Lu, Y., Zhou, L., Bruton, G., \& Li, W. (2010). Capabilities as a mediator linking resources and the international performance of entrepreneurial firms in an emerging economy. Journal of International Business Studies, 41(3), 419-436.

Luo, Y. (2005). Transactional characteristics, institutional environment and joint venture contracts. Journal of International Business Studies, 36, 209-230.

Marano, V., Tashman, P. \& Kostova, T. (2017). Escaping the iron cage: Liabilities of origin and CSR reporting of emerging market multinational enterprises. Journal of International Business Studies, 48, 386-408.

Meyer, K. (2001). Institutions, transaction costs, and entry mode choice in Eastern Europe. Journal of International Business Studies, 32, 357-367.

Meyer, K. E., Estrin, S., Bhaumik, S. K., \& Peng, M. W. (2009). Institutions, resources, and entry strategies in emerging economies. Strategic Management Journal, 30, 61-80.

Meyer, J.W., \& Rowan, B. (1977). Institutionalized organizations: formal structure as myth and ceremony. American Journal of Sociology, 83, 340-363.

Miles, M. B., \& Huberman, A. M. (1994). Qualitative Data Analysis: An Expanded Sourcebook. Sage.

Muralidharan, E., \& Pathak, S. (2017). Informal institutions and international entrepreneurship. International Business Review, 26(2), 288-302.

O'Grady, S., \& Lane, H. W. (1996). The psychic distance paradox. Journal of International Business Studies, 27(2), 309-333. 
Oparaocha, G. O. (2015). SMEs and international entrepreneurship: An institutional network perspective. International Business Review, 24(5), 861-873.

Papyrina V. (2007). When, how, and with what success? The joint effect of entry timing and entry mode on survival of Japanese subsidiaries in China. Journal of International Marketing, 15(3), 73-95.

Pinkham, B. C., \& Peng, M. W. (2017). Overcoming institutional voids via arbitration. Journal of International Business Studies, 48(3), 344-359.

Prashantham, S., Eranova, M., \& Couper, C. (2018). Globalization, entrepreneurship and paradox thinking. Asia Pacific Journal of Management, 35(1), 19.

Puffer, S. M., McCarthy, D. J., \& Boisot, M. (2010). Entrepreneurship in Russia and China: The impact of formal institutional voids. Entrepreneurship Theory and Practice, 34(3), 441-467.

Revista Pib (2012). Entrevista Marco Stefanini. 12.01.2012. Available at: http://www.revistapib.com.br/noticias_visualizar.php?id=802

Rodrik, D. (2004). Institutions and economic performance - getting institutions right. CESIfo DICE report, ISSN 1613-6373, ifo Institut für Wirtschaftsforschung an der Universität München, München, 2(2), 10-15.

Rodrik, D. (2017). Rescuing economics from neoliberalism. Boston Review, 6, 6-10.

Roy, J., \& Oliver, C. (2009). International joint venture partner selection: The role of the host-country legal environment. Journal of International Business Studies, 40, 779-801.

Rule, P., \& John, V. M. (2015). A necessary dialogue: Theory in case study research. International Journal of Qualitative Methods, 14(4), 1-11.

Salimath, M. S., \& Cullen, J. B. (2010). Formal and informal effects on entrepreneurship: a synthesis of nation-level research. International Journal of Organizational Analysis, 18(30), 358-385.

Scott, W. R. 1987). The adolescence of institutional theory. Administrative Science Quarterly, 32, 493-511.

Sethi, D., \& Judge, W. (2009). Reappraising liabilities of foreignness within an integrated perspective of the costs and benefits of doing business abroad. International Business Review, 18(4), 404-416. 
Shapiro, D.M., Li, J., \& Feng, C.M. (2020) Exploring the liability of origin: lessons from Smithfield Foods and Meat Processing in the US during Covid-19. AIB Insights, 20(3), published online.

Shirokova, G., \& McDougall-Covin, P. (2012). The role of social networks and institutions in the internationalization of Russian entrepreneurial firms: Do they matter?. Journal of International Entrepreneurship, 10(3), 177-199.

Sigmund, S., Semrau, T., \& Wegner, D. (2015). Networking ability and the financial performance of new ventures: moderating effects of venture size, institutional environment, and their interaction. Journal of Small Business Management, 53(1), 266283.

Suddaby, R., Bitektine, A., \& Haack, P. (2017). Legitimacy. Academy of Management Annals, 11, 451-478.

Tang, R. W., \& Buckley, P. J. (2020). Host country risk and foreign ownership strategy: Meta-analysis and theory on the moderating role of home country institutions, International Business Review, 29(4), published online.

Terjesen, S., \& Hessels, J. (2009). Varieties of export-oriented entrepreneurship in Asia. Asia Pacific Journal of Management, 26(3), 537-561.

Tiwari, S. K., Sen, S., \& Shaik, R. (2016). Internationalization: a study of small firms from emerging markets. Journal of Developing Areas, 50(6), 355-364.

Tomizawa, A., Zhao, L., Bassellier, G., \& Ahlstrom, D. (2020). Economic growth, innovation, institutions, and the Great Enrichment. Asia Pacific Journal of Management, 37(1), 7-31.

Turcan, R. V., \& Fraser, N. (2016). An ethnographic study of new venture and new sector legitimation: Evidence from Moldova. International Journal of Emerging Markets, 11(1), 72-88.

UOL Economia (2018). UOL Economia. Tecnologia a construir. Available at: https://www.uol/economia/especiais/entrevista-uol-lideres-marco-

$\underline{\text { stefanini.htm\#tecnologia-a-construir }}$

Vahlne, J. E., Schweizer, R., \& Johanson, J. (2012). Overcoming the liability of outsidership - the challenge of HQ of the global firm. Journal of International Management, 18(3), 224-232.

Vahlne, JE., \& Johanson, J. (2017). From internationalization to evolution: The Uppsala model at 40 years. Journal of International Business Studies, 48, 1087-1102. 
Walder, A. G. (2011). From control to ownership: China's managerial revolution. Management and Organization Review, 7(1), 19-38.

Webb, J. W., Khoury, T. A., \& Hitt, M. A. (2020). The influence of formal and informal institutional voids on entrepreneurship. Entrepreneurship Theory and Practice, 44(3), 504-526.

Wei, T., Clegg, J. \& Ma, L. (2015). The conscious and unconscious facilitating role of the Chinese government in shaping the internationalization of Chinese MNCs, International Business Review, 24(2), 331-343.

Welch, C., Piekkari, R., Plakoyiannaki, E., \& Paavilainen-Mäntymäki, E. (2011). Theorising from case studies: Towards a pluralist future for international business research. Journal of International Business Studies, 42(5), 740-762.

Wu, J., Wang, C., Hong, J., Piperopoulos, P., \& Zhuo, S. (2016). Internationalization and innovation performance of emerging market enterprises: The role of host-country institutional development. Journal of World Business, 51(2), 251263.

Volchek, D., Jantunen, A., \& Saarenketo, S. (2013). The institutional environment for international entrepreneurship in Russia: Reflections on growth decisions and performance in SMEs. Journal of International Entrepreneurship, 11(4), 320-350.

Yaprak, A., Yosun, T., \& Cetindamar, D. (2018). The influence of firm-specific and country-specific advantages in the internationalization of emerging market firms: Evidence from Turkey. International Business Review, 27(1), 198-207.

Yin, R. K. (2017). Case study research and applications: Design and methods. Newbury Park: Sage.

Zaheer, S. (1995). Overcoming the liabilities of foreignness. Academy of Management Journal, 38(2), 341-363.

Zhang, J., Deephouse, D.L., Van Gorp, D., \& Ebbers, H. (2020). Individuals' perceptions of the legitimacy of emerging market multinationals: Ethical foundations and construct validation. Journal of Business Ethics. https://doi.org/10.1007/s10551$\underline{020-04599-x}$

Zhang, W., \& White, S. (2016). Overcoming the liability of newness: Entrepreneurial action and the emergence of China's private solar photovoltaic firms. Research Policy, 45(3), 604-617. 
Zettinig, P., \& Benson-Rea, M. (2008). What becomes of international new ventures? A coevolutionary approach. European Management Journal, 26(6), 354-365.

Zhou, N. (2018). Overcoming the liability of emergingness. Academy of Management Proceedings $2018 . \quad$ Available at: https://journals.aom.org/doi/abs/10.5465/AMBPP.2018.11328abstract 
Paper 3 - Institutional Distance and Perceived Institutional Familiarity - A Case Study of a German Information Technology Company

\section{Abstract}

This study uses an in-depth case study to examine the interplay between institutional distance and perceived institutional familiarity between headquarters and subsidiary in a context of large institutional differences. The case selected portrays a German IT company entering Turkey. A longitudinal approach was used based on retrospective interviews and secondary data. The study confirms, at a micro level, that historical ties and the proximity of immigration groups in the home country may increase the attractiveness of a host country for foreign direct investment in the country of origin of these immigrants. In such circumstances, the firm may use members of the immigrant group to staff the subsidiary and thus build an institutional "bridge" capable of translating differences and blending capabilities, even when the institutional distance between the two countries is increasing. The study also provides evidence that perceived familiarity has a potential neutralizing impact on institutional distance concerning market entry. Moreover, perceived institutional familiarity in the cognitive pillar may help to bridge differences in the normative and regulatory pillars.

\section{1}

\section{Introduction}

The concept of distance has received substantial attention in the International Business (IB) field. Several aspects of distance have been examined in IB studies: geographic distance, psychic distance, cultural distance, and more recently, institutional distance. All these constructs are similar, but they differ as to what they include, or do not include, in their conceptual domain. This paper is concerned with institutional distance (Kostova et al., 2020), that is, the differences between the institutional 
environment of the home country of a firm and the country that hosts a foreign direct investment of this same firm (host country). In the center of the debate on the impact of institutional distance on international business is the decision to establish a subsidiary in a host country that substantially differs from the home country in terms of institutional dimensions (regulatory, normative, or cognitive). Different hypotheses have been advanced by scholars to explain the dynamics of this decision, but no definitive answer has been given yet. Van Hoorn and Maseland (2016, p.374) claim that IB research using an institutional perspective fails to explain "how institutions matter" and suggest a need for "a more careful theoretical and empirical distinction between the effects of institutions and institutional distance on cross-border business activities."

Bae and Salomon (2010, p.339) have already argued, a decade ago, that the understanding of the institutional distance construct was still quite limited, particularly concerning how it impacted firm decisions in an international context, that is, "the issue of mechanisms that underlie the workings of institutional dimensions." They posed three relevant questions. The first question was about the relative weight of different dimensions of institutional distance in international business decisions, and whether their relative importance changed across time. The second question was whether one dimension could counterbalance the impact of another dimension (e.g., cultural similarity could help overcome, or reduce, regulatory distance), and, conversely, whether these dimensions might have an independent impact on specific international business decisions. The third question addressed the issue of how these dimensions coevolve. To the researcher's knowledge, despite many studies have looked at institutional distance and provided some evidence in a way or another, these questions remain largely open for further research.

Another construct, which has been investigated more recently, is perceived institutional familiarity (Schwens \& Kabst, 2011), which deals with an apparently opposite situation, that is, when management perceives a host country as familiar (but not necessarily similar to the home country). However, the literature has not addressed the interplay between these two constructs - institutional distance and perceived institutional familiarity - in the context of entry and operation in a host country with large institutional differences.

Therefore, this study aims at investigating the following research questions: (1)

How is the interplay between a high level of institutional distance between the headquarters and a subsidiary, and the perceived institutional familiarity with some 
aspects of the host environment of the entrepreneurs leading the firm? (2) How does institutional distance and perceived familiarity impact the decisions along the subsidiary's trajectory in time?

Using an in-depth case study, this article examines the entry and operation of an entrepreneurial company, currently in a process of international expansion. Specifically, the study looks at the establishment of a subsidiary in a country with profound differences in the three pillars of the institutional environment: regulatory, normative and cognitive. The case selected for the study deals with the internationalization of Adesso, a German multinational company in the information technology (IT) sector. The study focuses specifically on the company's entry and operation in Turkey. Thus, the article proposes to explore the interplay between two constructs that coexist in the institutional theory literature: institutional distance and institutional familiarity and how they impact the FDI decision.

\section{2 \\ Theoretical Background}

This section discusses three relevant topics to answer the research question. First, the institutional distance construct and the ways in which it has been measured in the literature are examined. Second, the impact of the construct on international business decisions is examined. Third, the perceived institutional familiarity construct is discussed.

\subsection{1}

\section{Institutional distance}

The institutional distance construct refers to the differences between countries regarding the institutions that predominate in them. Table 1 presents some definitions of this construct, which became popular in IB (Bae \& Solomon, 2010; Kostova \& Zaheer, 1999; Kostova et al., 2020; Rana \& Nipa, 2019) due to the expansion of multinationals from developed countries to less developed markets, whose institutional environments differed from those of the multinationals' home countries. 
Table 1 - Definitions of institutional distance according to the literature

\begin{tabular}{|c|c|}
\hline Definition & Author \\
\hline $\begin{array}{l}\text { "The difference between the institutional profiles of two } \\
\text { countries, typically the home and the host country of an } \\
\text { MNC." }\end{array}$ & Kostova et al $(2019$, p. 468) \\
\hline $\begin{array}{l}\text { "The difference between the regulatory, cognitive and } \\
\text { normative environments of the home and host countries of } \\
\text { multinational enterprises (MNEs)." }\end{array}$ & $\begin{array}{l}\text { Shirodkar \& Konara (2017, } \\
\text { p.180) }\end{array}$ \\
\hline $\begin{array}{l}\text { "The institutional distance concept helps measure the } \\
\text { difference of various institutional features between two or } \\
\text { more countries, for example, political risks, regulative } \\
\text { differences, norms affecting authority and trust, executive } \\
\text { rationales and mind-sets for decision making, etc." }\end{array}$ & Rana \& Nipa (2019, p.5) \\
\hline $\begin{array}{l}\text { "The extent of difference between countries in institutional } \\
\text { context." }\end{array}$ & Salomon \& Wu (2012, p.9) \\
\hline
\end{tabular}

For Kostova (2020), the institutional distance is based on Scott's 'three pillars' (1995) and can be defined as the difference between regulatory, normative and cognitive institutions between two or more countries. This is explained by the way in which different countries impose different ways of legitimizing functions (Kostova, 2020). For North (1990), the institutional distance construct has its roots in institutional economics. The formal institutional distance includes differences in laws and regulations, as well as differences in rules that define ways of doing business and formal governance rules; the informal institutional distance, on the other hand, includes differences between norms, values and shared beliefs, as well as differences in commonly adopted practices, in addition to language differences between countries (Abdi \& Aulakh, 2012; Estrin, Baghdasaeyan \& Meyer, 2009; Slangen \& Beugelsdijk; 2010; Zhu, Xia \& Makino, 2015).

Measuring institutional distance is commonly done using objective indicators. Databases such as the World Bank's World Governance Indicators (WGI), the Heritage Foundation's Economic Freedom Index (EFI), the IMD's World Competitiveness Yearbook (WCY) and the Global Competitiveness Report (GCR) (World Economic Forum) are generally used to measure the regulatory institutional distance (voice and responsibility, political stability and absence of violence, government effectiveness, regulatory quality, rule of law, corruption control, fiscal freedom, government spending, freedom of business, freedom of work, monetary freedom, freedom of trade, freedom of investment) (Kostova et al., 2020). Kostova et al. (2020) also state that governance indicators (WGI) and the Economic Freedom Index (EFI) can also be used for normative distance measures. 
The dimensions of cognitive distance are commonly measured using the cultural dimensions of Hofstede (2011). Hofstede (2011, p.3) defines culture as "the collective programming of the mind that distinguishes the members of one group or category of people from others." Also, he defines "cultural dimension" as "an aspect of a culture that can be measured relative to other cultures." Since 1980 Hofstede has developed several studies involving executives, the purpose of which was to identify the cultural dimensions related to work. The first studies, which are presented in the book Culture's Consequences (Hofstede, 1980), entailed four cultural dimensions. The four dimensions initially identified were: Power Distance, Uncertainty Avoidance, Individualism versus Collectivism, and Masculinity versus Femininity. Later, other studies (Hofstede \& Bond, 1988; Hofstede, 1991) identified a fifth dimension, which would be present in Asian cultures: Long Term versus Short Term Orientation. Finally, a sixth dimension was included: Indulgence versus Restraint (Hofstede, Hofstede \& Minkov, 2010; Hofstede, 2011). The definition of each dimension according to Hofstede is presented in Table 2.

Table 2 - Hofstede's Cultural Dimensions

\begin{tabular}{|l|l|}
\hline Cultural Dimension & Conceptualization \\
\hline Power Distance & $\begin{array}{l}\text { "related to the different solutions to the basic problem of human } \\
\text { inequality." }\end{array}$ \\
\hline Uncertainty Avoidance & $\begin{array}{l}\text { "related to the level of stress in a society in the face of an } \\
\text { unknown future." }\end{array}$ \\
\hline $\begin{array}{l}\text { Individualism versus } \\
\text { Collectivism }\end{array}$ & "related to the integration of individuals into primary groups." \\
\hline $\begin{array}{l}\text { Masculinity versus } \\
\text { Femininity }\end{array}$ & $\begin{array}{l}\text { "related to the division of emotional roles between women and } \\
\text { men." }\end{array}$ \\
\hline $\begin{array}{l}\text { Long Term versus Short } \\
\text { Term Orientation }\end{array}$ & $\begin{array}{l}\text { "related to the choice of focus for people's efforts: the future or } \\
\text { the present and past." }\end{array}$ \\
\hline $\begin{array}{l}\text { Indulgence versus } \\
\text { Restraint }\end{array}$ & $\begin{array}{l}\text { "related to the gratification versus control of basic human desires } \\
\text { related to enjoying life." }\end{array}$ \\
\hline
\end{tabular}

Source: Organized from Hofstede $(2011$, p.8)

Power Distance thus refers to whether or not the less privileged members of a society believe that power is distributed unevenly among those who participate in it. Uncertainty Avoidance is related to the level of stress with which members of a society deal with an unknown future and how comfortable or uneasy they are with unstructured situations. Individualism and Collectivism are opposites on a continuum and refer to the degree to which members of a society are concerned with the collective well-being or if they seek individual or small group interests (such as the family). The Masculinity 
versus Femininity dimension, on the other hand, deals with the predominant values in a society: masculine values such as assertiveness and competition, or feminine values such as care and modesty. In male societies, there is a strong differentiation between the emotional roles of men and women, while in female societies this difference, although existing, is much smaller. In female societies women participate more in the political arena. The fifth dimension, Long Term versus Short Term Orientation, refers to the time horizon to which the society directs its efforts. Values such as consumption and slow economic growth are linked to short-term orientation, whereas savings, availability of resources for investment and rapid economic growth characterize long-term oriented societies. The Indulgence versus Restraint dimension was added in 2010 and has to do with the search for gratification versus the control of human desires. An indulgent society enjoys life and has fun, while in a more restrictive society rules of conduct control the desire for gratification (Hofstede, 2011).

In addition to Hofstede's cultural dimensions, several other studies in the area of Comparative Management have identified other sets of dimensions, such as the GLOBE project (Taras et al., 2002). Nevertheless, due to its simplicity and the small number of dimensions, Hofstede's contribution continues to be widely used by scholars of International Business (Hutzschenreuter et al., 2015; Taras et al., 2009; Tung \&Verbeke, 2010).

\subsection{2 \\ The role of institutional distance in IB decisions}

How do firms cope with institutional distance? This question has been addressed by several studies, but there is surprisingly little agreement among them. Most studies focus on the role of institutional distance on host market selection, and entry and operation mode decisions. As to market entry, Xu and Shenkar (2002, p. 614) suggest that "firms will refrain from investing in markets that are institutionally distant, because business activities in those markets require conformity to institutional rules and norms that conflict with those of the home country." Yet Phillips et al. (2009) propose that when considering distant markets, it is the combination of difference and uncertainty that will keep a firm away or not from an institutionally distant market. However, other studies show that several mechanisms may influence the choice of a foreign market with high institutional distance. For example, Quer et al. (2019) found that Chinese firms 
enter markets with high institutional distance without having any prior experience, when these countries had been visited by Chinese government officials, indicating that political ties between countries may help overcome institutional distance. From a similar perspective, Kedia and Bilgili (2015) find that historical ties between the home and the host country can reduce institutional distance in terms of market selection. Similar findings are reported by Liou and Rao-Nicholson (2017) in the context of South African firms.

Concerning the entry and operation mode, there is also substantial evidence available, but they often also point out to different, although not always conflicting, possibilities. For example, Gaur and Lu (2007) find that the largest the institutional distance, the more important is to have more ownership of a subsidiary, but Hernández and Nieto (2015) observe that firms use lower commitment entry modes when entering markets with a lower level of regulatory development. In terms of acquisitions, there is evidence that firms in high-tech industries, when faced with high institutional distance and having experience with acquisitions prefer full acquisitions than partial ones (Elango, Lahiri \& Kundu, 2013). Regarding the impacts of different dimensions of institutional distance (a question previously posed by Bae and Salomon, 2010), research with Finnish and Central and Eastern European firms showed that high normative distance favors the choice of wholly-owned subsidiary, but that regulatory distance does not influence the decision (Arslan \& Larimo, 2010). Shirodkar and Konara (2017) advance that high institutional distance negatively impacts subsidiary performance in emerging markets, but this impact is reduced when there is only partial ownership. In the context of emerging market firms, Liou, Chao and Yang (2016) find that a large informal institutional distance favors low levels of ownership, but large formal institutional distance favors majority control of the subsidiary.

Other decisions concerning the subsidiary are also influenced by institutional distance. For example, Salomon and $\mathrm{Wu}$ (2012) find that some firms adopt local isomorphism, that is, they imitate domestic firms in order to adapt to the new institutional environment. However, Fortwengel (2017) claims that international firms may behave in ways that deviate from the established behavior of domestic firms. Another study (Van den Waeyenberg \& Hens, 2012) conciliates both approaches, suggesting that certain capabilities can be transferred (mainly procedural capabilities), while new ones need to be developed, typically by means of partnerships and alliances with local players. A study with foreign subsidiaries of Japanese firms (Ando \& Paik, 
2012) finds that staffing decisions are associated to the level of institutional distance; firms with international experience increase the number of home country nationals in markets with high institutional distance, but, in general, the ratio of home country nationals to local employees decreases with higher institutional distance. Another study shows that the quality of the relationship between the subsidiary and the headquarters of Chinese firms is positively related to the degree of institutionalization of headquarters practices within the subsidiary (Li, Jiang \& Shen, 2016).

\subsection{3}

\section{Perceived institutional familiarity}

The perceived institutional familiarity construct is new in the area of international entrepreneurship. The construct is conceptualized as "the extent to which the firm's management assumes to be familiar with the rules, norms, and values in terms of, for instance, formal legal decisions or formal regulative issues." (Schwens \& Kabst, 2011, p.61). This definition is restrictive, because it takes into consideration mainly the regulatory and normative pillars of the institutional environment but does not consider the cognitive pillar.

Pedersen and Pedersen (2004) define the lack of familiarity with foreign markets as the perceived lack of knowledge regarding an operation in a foreign market (Pedersen \& Petersen, 2004). According to Eriksson et al. (1997), knowledge of the foreign market can be of two kinds: institutional knowledge and market knowledge. Institutional knowledge refers to knowledge about rules, norms and values for a particular country. Market knowledge refers to the knowledge about suppliers, distributors, customers, and competitors. The authors operationalize the construct "lack of market knowledge" using two indicators: lack of foreign subsidiaries or representatives or companies abroad; and lack of cooperation agreements with partners of several kinds. The "lack of institutional knowledge" construct has indicators such as knowledge of language, laws, norms and standards in foreign markets. They also refer to a third construct, "lack of knowledge of internationalization", which encompasses the lack of experience in doing business abroad and the lack of unique knowledge or competence. The authors suggest that the experience in internationalization impacts market knowledge and institutional knowledge. 
The original Uppsala model (Johanson \& Vahlne, 1977) already considered that the psychic distance between the home country and the country of destination would impact market selection and entry mode decisions. Firms with limited international experience tend to choose foreign markets similar to their home country, which tended to be, but not necessarily, geographically closer. However, as firms accumulate experiential knowledge in a foreign market, and, therefore, it becomes more familiar, the impact of psychic distance decreases.

Pedersen \& Petersen (2004) identified three different situations by which perceived familiarity with the host country business environment evolves after a firm enters a new foreign market. The first situation assumes that the opportunities for preentry learning are limited; learning occurs post-entry. This is in line with the Uppsala model, which predicts that experiential learning can only occur once the firm actually enters a foreign market, and what can be obtained pre-entry is objective knowledge, which is not as valuable and useful. In addition, the Uppsala model predicts that knowledge acquisition occurs in a stepwise manner. The second situation considers that entrant firms experience a shock effect in the 'post-entry' period, due to lack of familiarity with the foreign market. Finally, the third situation assumes that the shock effect increases with the time of operations.

Schwens and Kabst (2011) developed and tested a model based on data from German technology companies. In this study, the authors examine the construct of perceived institutional familiarity, which is seen as composed of foreign market analysis (the extent to which the company collects specific market information before entering the market), interaction with foreign market participants (the extent to which the company interacts with customers, suppliers and other cooperative partners in the foreign market) and exposure to particularities of the foreign market (the extent to which the company is exposed to new market segments, different market forces or changes in customer preferences in the foreign market). The authors found that previous analysis of the foreign market is positively related to perceived institutional familiarity and they suggest that the systematic approach to supporting internationalization in the context of technology companies is important even before entry, although technology companies proactively internationalize. Hence, the authors argue that what technology companies know about foreign markets arises both systematically and proactively. Their recommendation is to investigate these complex topics with in-depth empirical research using mixed method designs, including case study research. 
The economics literature has looked at a similar construct, cultural proximity, which has been found to influence trade (Felbermayr \& Toubal, 2010) and foreign direct investment flows (Fiorini et al., 2021). Wang et al. (2014) assert that it is easier for firms to engage in business with culturally close partners because of reduced uncertainty, which, in turn, makes it easier to share knowledge. These authors see cultural proximity as "a culture-specific advantage for a specific group of firms" (p. 9). Interestingly, Buch et al. (2006) investigated the relationship between investment flows and migration in Germany, finding that countries to which Germans migrated in the past are a preferred recipient for German FDI. Akcaoglu and Wehner (2018) claim that the large immigration of Turks to Germany and their German citizenship has influenced the flows of trade and investment between the two countries, with Germany becoming the largest trading partner and one of the largest investors in Turkey. Schäffler et al. (2017), examining German FDI in the Czech Republic, find a positive influence of cultural proximity and cross-border networks. Buch et al. (2003) find that among the factors that increase German FDI in foreign countries are a common language. a common border, low country risk and a high degree of freedom.

In the present study, the interplay between institutional distance and perceived institutional familiarity is examined, adopting Kostova et al.'s (2020) definition of institutional distance, but extending Schwens and Kabst's (2011) conceptualization of perceived institutional familiarity to include the three domains of the institutional environment: regulatory, normative, and cognitive.

\section{3 \\ Method}

This article uses the case study research method, which allows for the analysis of a specific situation within its context (Ghauri, 2004). The method is particularly useful when the research aims to investigate poorly structured problems that would not readily lend themselves to the use of quantitative methods.

Theoretical sampling was used to select the case to be studied. Theoretical sampling "simply means that cases are selected because they are particularly suitable for illuminating and extending relationships and logic between constructs" (Eisenhardt \& Graebner, 2007, p.27). A single case was chosen to explore the relationships between the institutional distance and perceived institutional familiarity constructs in the context 
of the internationalization of a developed country company that begins operations in an emerging market, in which the institutional environments differ strongly in what refers to the three institutional pillars: regulatory, normative and cognitive. The case was chosen using the following criteria:

(i) the company should present the characteristics of an entrepreneurial company;

(ii) it should come from a country of high institutional quality;

(iii) it should have achieved a leadership position in the IT industry in its area of operation;

(iv) it should present a relevant internationalization trajectory; and

(v) it should have entered an emerging market whose institutional environment was significantly different from the institutional environment of its home country.

Thus, after checking other possibilities, the Adesso SE case was selected because it met all the above-stated conditions and because accessing it would be facilitated by the Technical University of Dortmund, where the researcher carried out the study during a research internship.

Table 3 - Characteristics of the selected case

\begin{tabular}{|l|l|}
\hline Company & Adesso SE \\
\hline Country of origin & Germany \\
\hline Year founded & 1997 \\
\hline First Internationalization & 2007 (10 years after its founding) \\
\hline Revenue & 449.704 million Euros (2019) \\
\hline Product portfolio & Custom software solutions for business, IT services \\
\hline
\end{tabular}

To carry out the study, secondary data and primary data were collected. The secondary data were obtained on the company's website through documents available on the website and in the annual reports of the Adesso group, newspaper and blog articles, and the group's newsletter.

The primary data were obtained through in-depth interviews with the company's main executives involved with strategic internationalization decision-making, in addition to an internationalization specialist (Table 4). The interviews were conducted in Germany, Adesso SE's country of origin, both in person and online, in the interviewees' native language, with the exception of Adesso's CEO in Turkey. The script consisted of open-ended questions, with new questions being added throughout 
the process as the interviewees' narratives opened the door to exploring new issues. In total, there were four interviews, which were recorded and transcribed.

Table 4 - Interviewee Profile

\begin{tabular}{|l|l|l|l|l|}
\hline Name & Volker Gruhn & $\begin{array}{l}\text { Rüdiger } \\
\text { Striemer }\end{array}$ & Burak Bari & Dominik Stute \\
\hline $\begin{array}{l}\text { Current } \\
\text { Position }\end{array}$ & $\begin{array}{l}\text { Founder/President } \\
\text { of the } \\
\text { Administrative } \\
\text { Council }\end{array}$ & $\begin{array}{l}\text { Co- } \\
\text { founder/Member } \\
\text { of the Council }\end{array}$ & $\begin{array}{l}\text { CEO Adesso } \\
\text { Turkey }\end{array}$ & $\begin{array}{l}\text { Responsible for the } \\
\text { internationalization } \\
\text { area at the Dortmund } \\
\text { Chamber of } \\
\text { Commerce }\end{array}$ \\
\hline Nationality & German & German & Turkish & German \\
\hline
\end{tabular}

The data were analyzed following the procedure recommended by Ghauri (2004), which initially consists of a detailed description of the case studied, followed by a comparison of the evidence found using the theoretical patterns examined in the relevant literature (pattern-matching analysis). There was concern with the triangulation of the data obtained, in order to guarantee the reliability and validity of the research. The triangulation took place by comparing the data from the different interviews and comparing the data obtained through primary and secondary sources.

\section{4 \\ The Technology Information Industry in Germany and the Dortmund Area}

In Germany the sector is represented by approximately 100,000 companies with an estimated revenue of 230 billion euros (Deloitte, 2019). The sector is responsible for approximately $7 \%$ of Germany's GDP. In recent years Germany has faced strong global competition due to digitization, which has led to the evolution of the software segment and IT services. The German technology market has experienced strong growth since 2000 and more than doubled its revenue by $2018(+104 \%)$. The sector has followed the trend of rapid digitization, meeting the demand for different software formats, and offering a wide variety of complex digital solutions and IT services. The German IT sector is characterized by strong integration with the mechanical engineering, financial services, telecommunications and public administration sectors. With regard to exports, the software and services sector had a worth of 27 billion euros and the hardware segment 78 billion euros. Destination countries are fragmented, but software and service exports are aimed mainly at German-speaking countries (Austria and Switzerland) and 
hardware exports are geared toward major European markets, particularly Britain, France and Italy (Deloitte, 2019 ).

The general structure of the IT sector, both in Germany and in other European countries, is characterized predominantly by small and medium-sized companies, which, due to their skills, flexibility and strategic agility, provide dynamism to the sector. However, the sector does not lead the global IT trends, as explained by Dominik Stute, of the Dortmund Chamber of Commerce, in an interview with the researcher:

"We don't have a Google or Facebook... Maybe that allows for better dynamics, as small businesses can change course more quickly, can react differently, are a little more detailed and, in some way, cover all areas... But in the international context, things could be better. Like in the IT sector, maybe all the big players are in the USA and China, which is why that here in Germany you may be good at what you do, but you are not the trendsetter, nor are you the one who defines things... How can I put it?... You react well; you are good at what you do, but you don't lead."

In the interviewee's opinion, German IT products have a great advantage in terms of reputation, quality and processes when compared with competitors from other countries, but they present, as a disadvantage, "German perfectionism," which, in his opinion, would be "the great villain" for the development and evolution of companies, especially technology startups:

"Before anything, in the IT area, the main thing is the good German reputation - 'Made in Germany' - which carries a certain basic confidence. The advantages are there, but there are also the disadvantages. I think the advantages are protection, reliability, sufficiency, quality, European servers... These are advantages for Germans. But at the same time there are also disadvantages. Things are a bit more complicated when it comes to startups. In comparison with other countries, in Germany you need a little more time. Germans always want to bring the perfect product to the market, so you don't always develop the prototype so fast. Companies typically lose out to competition [in speed of development]. I think it is the result of the German mentality. You focus and work on a product until it's perfect and that can take three years if you're lucky. The Americans and the Chinese can introduce a semi-finished product into the market after just a year..."

The city of Dortmund is located in the state of Ruhr and Westphalia and is the birthplace of Adesso. The city was an important supplier of coal and a producer of steel during the Industrial Revolution. Exactly for these characteristics, it was strongly affected by bombings during the Second World War, but it was rebuilt and renewed from the 1950s onwards, becoming an important technology hub. Dortmund is one of the largest IT centers in Germany, bringing together a large number of related companies and institutions. The region has universities and research institutes that support technological advancement. The Technical University of Dortmund is the second most important in the region. It has the Center for Entrepreneurship and Transfer 
(CET), which maintains contacts with associations of interest to the technology area, such as the regional association of IT entrepreneurs in the East Ruhr and Westphalia Region, with around 60 member companies. The network is particularly strong in the region around Dortmund.

\section{5 \\ The Case of Adesso SE}

\subsection{1 \\ Background}

Adesso SE was founded in 1997 in Dortmund, Germany, at the time when one of its founders, Volker Gruhn, Doctor in Computer Science worked as an Assistant Professor at the Technical University of Dortmund. At the time of its founding, Adesso sought to offer customized software processes and solutions to companies, with a focus on the German-speaking market. Almost 25 years after its founding, Adesso is one of the most dynamic IT companies in Germany and Central Europe (Adesso Group, 2019) with sales growth of more than $20 \%$ in 2019 . The company has grown based on a history of mergers, acquisitions and investment in the product portfolio.

In 2007 the company entered the international market for the first time through investments. However, the strategic focus on internationalization was only declared in 2018, when the company was already present with investments in five countries. With a total of 3,328 employees in Germany and 705 abroad in 2019, Adesso was considered a large company in the sector in its region, but not in comparison with the major IT companies worldwide, as noted by Dominik Stute of the Dortmund Chamber of Commerce:

“... in North Rhine-Westphalia we have a structure of small and medium-sized companies in the IT area. Even Adesso and Materna, which are the main IT companies in the region, are relatively small if you compare them to other, very large IT companies."

Adesso's international growth is evidenced by the growth in the number of its employees abroad, which increased by $46 \%$ in 2019 , greater than the increase in the number of employees in Germany, which was $19 \%$. In addition, it is a company with a good working environment, having repeatedly received the "Best Place to Work" award. The company is publicly traded. In 2019 it took a strategic step towards the 
consolidation of its international strategy, becoming a European company (Societas Europaea / SE).

In its 2019 report, Adesso defined its mission as offering customers a specialized consultancy based on in-depth knowledge of the IT industry, in order to provide customized and innovative software solutions. The company's objective was defined as helping customers to make the most of their business potential, enabling their future flexibility (Adesso Group, 2019). The company's differentials, according to Burak Bari, CEO of Adesso Turkey, "are quality, service and product, and what results from that," based on a long-term relationship of trust with customers and suppliers, which results from a company's "approach" and "thinking” in relation to building partnerships.

In 2021, in addition to Adesso SE's headquarters in Dortmund, the company maintained 19 other offices in Germany's main economic regions. In addition to Adesso SE, its headquarters and largest operating unit, the Adesso Group has 25 subsidiaries, four associated companies and a joint venture. Adesso works with two distinct segments: IT Services and IT Solutions. While the IT Services segment offers customized, project-oriented services in the areas of consulting and software development, the IT Solutions businesses market their own standard software solutions or products. Table 5 presents company data and Figure 1 shows the sales growth. Table 6 displays the timeline with the evolution of the company.

Table 5 - Adesso SE data

\begin{tabular}{|l|l|l|l|l|}
\hline Indicator & $\begin{array}{l}2019 \\
\text { (in million } \\
\text { euros) }\end{array}$ & $\begin{array}{l}2018^{*} \\
\text { (in million } \\
\text { euros) }\end{array}$ & $\begin{array}{l}\text { Growth } \\
\text { (in million } \\
\text { euros) }\end{array}$ & $\begin{array}{l}\text { Growth } \\
\%\end{array}$ \\
\hline Sales Revenue & 449.704 & 375.648 & 74.056 & 20 \\
\hline Domestic & 360.987 & 308.742 & 52.245 & 17 \\
\hline International & 88.717 & 66.906 & 21.811 & 33 \\
\hline Employees & 4,033 & 3,280 & 753 & 23 \\
\hline In the country & 3,328 & 2,797 & 531 & 19 \\
\hline Abroad & 705 & 483 & 222 & 46 \\
\hline
\end{tabular}

Source: prepared by the author, based on Adesso Group's (2019) Annual Report 


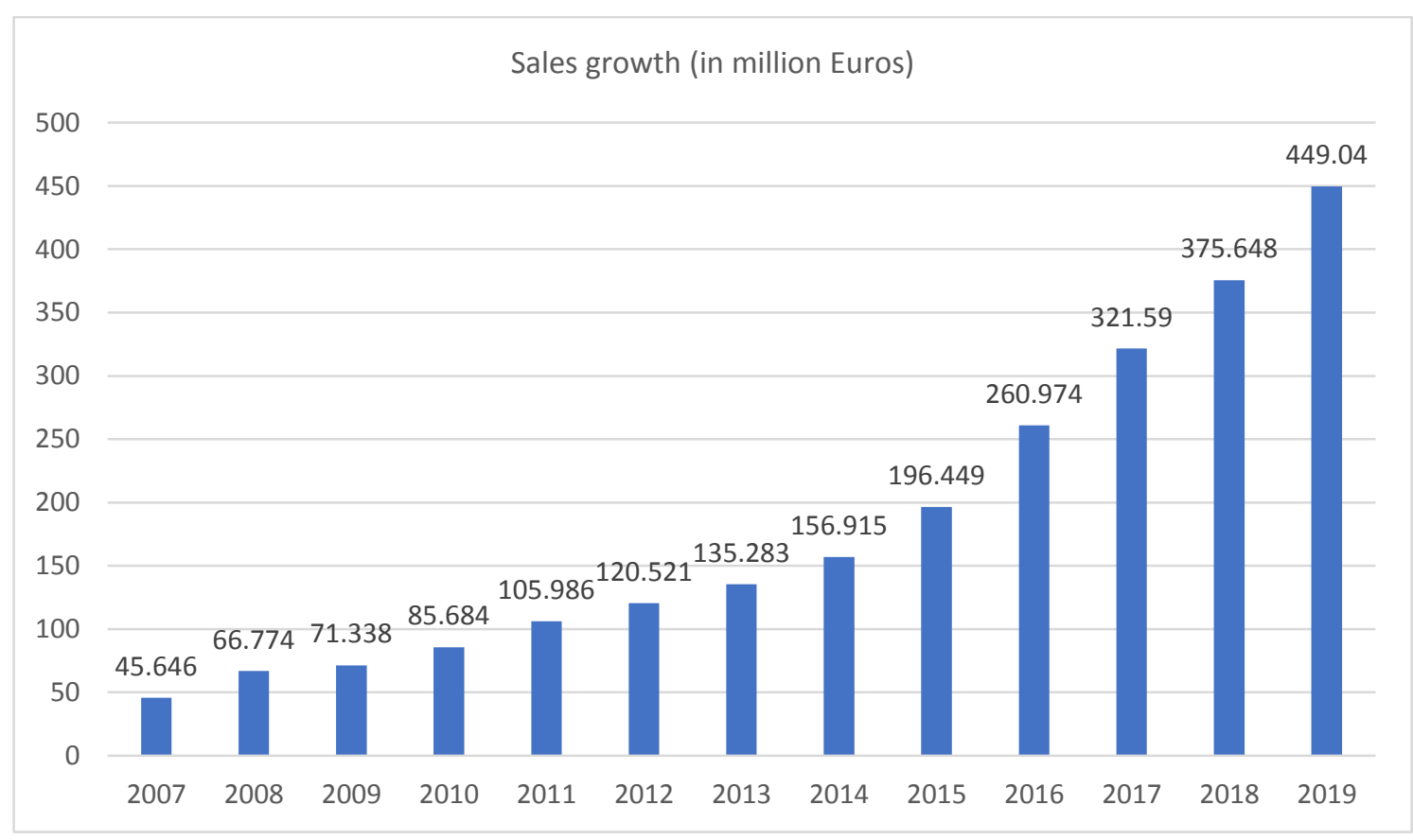

Figure 1 - Sales growth (in million euros)

Source: prepared by the author, based on Adesso Group's (2019) Annual Report

Table 6 - Adesso SE Time Line

\begin{tabular}{|c|c|}
\hline $\begin{array}{l}\text { Early years (1997- } \\
\text { 1999) }\end{array}$ & $\begin{array}{l}1997 \text { - Adesso founded as a consultancy for software process } \\
\text { management in Dortmund, Germany. } \\
1998 \text { - First project for the insurance industry. } \\
1999 \text { - First project for the lottery industry; Development of the first } \\
\text { products; Foundation of the companies e-Spirit AG and Adesso Mobile } \\
\text { Solutions GmbH. }\end{array}$ \\
\hline ears (2000- & $\begin{array}{l}2000 \text { - No. of employees increases to 100; Adesso reorganized as AG } \\
\text { (corporation). } \\
2003 \text { - No. of employees increases to } 200 \text {. } \\
2005 \text { - "Best Employer in Germany" award. } \\
2006 \text { - Expansion into the healthcare sector by acquiring control of } \\
\text { Gadiv GmbH. }\end{array}$ \\
\hline $\begin{array}{l}\text { Mergers, } \\
\text { acquisitions and } \\
\text { internationalization } \\
(2007-2010)\end{array}$ & $\begin{array}{l}2007 \text { - Internationalization with contracts in Russia, Spain and } \\
\text { Luxembourg; Opening of offices in Switzerland, Luxembourg and the } \\
\text { United Kingdom; Reverse IPO via merger with BOV AG. } \\
2008 \text { - No. of employees increases to 500; Best employer award "Top } \\
\text { Job." } \\
2009 \text { - Listed among the top } 20 \text { IT consulting and systems integration } \\
\text { companies in Germany; Access to the Austrian market through } \\
\text { acquisitions and formation of Adesso Austria GmbH. } \\
2010 \text { - Acquisition of the shareholder control of Evu.it GmbH to } \\
\text { reinforce the portfolio of services for the utilities sector and SAP } \\
\text { technologies; Another "Great Place do Work" award. Merger with } \\
\text { Sitgate AG to expand consultancy services in the IT management } \\
\text { sector }\end{array}$ \\
\hline $\begin{array}{l}\text { Expansion and } \\
\text { growth of portfolio } \\
(2011-2017)\end{array}$ & $\begin{array}{l}2011 \text { - Entry into the USA with opening of the Boston office; Revenue } \\
\text { exceeds } 100 \text { million euros. } \\
2012 \text { - No. of employees increases to more than 1,000; Purchase of } \\
\text { majority shares of the e-business specialist ARITHNEA GmbH; }\end{array}$ \\
\hline
\end{tabular}




\begin{tabular}{|c|c|}
\hline & $\begin{array}{l}\text { Another "Great Place do Work" award. } \\
2013 \text { - Entry into Turkey through a subsidiary based in Istanbul; Start } \\
\text { of operations of Adesso Hosting Services GmbH and Adesso } \\
\text { Transformer GmbH. } \\
2014 \text { - Expansion of the portfolio in the insurance sector, with an } \\
\text { integrated project. } \\
2015 \text { - The number of employees increases to more than 1,500; } \\
\text { Largest acquisition in the history of Adesso, the Swiss company Born } \\
\text { Informatik AG; Full participation in PSLife GmbH (insurance). } \\
2016 \text { - Expansion in Germany to four new locations; Another "Great } \\
\text { Place to Work" award as the best employer in the German IT industry; } \\
\text { Acquisition of Smarthouse Media GmbH to supplement the banking } \\
\text { portfolio. } \\
2017 \text { - Revenue exceeds } 300 \text { million euros; Acquisition of UnitCon } \\
\text { GmbH as a strategic reinforcement of the subsidiary ARITHNEA in } \\
\text { the area of SAP Customer Engagement, Business Analytics and } \\
\text { HANA. }\end{array}$ \\
\hline $\begin{array}{l}\text { Focus on } \\
\text { international } \\
\text { strategy (2018-2019) }\end{array}$ & $\begin{array}{l}2018 \text { - Foundation of companies in Spain and Bulgaria; The number of } \\
\text { employees exceeds 3,200; Best employer in the IT sector large } \\
\text { company category. } \\
2019 \text { - Conversion from being a German to a European company } \\
\text { (Societas Europaea / SE); founding of national Adesso companies in } \\
\text { the Netherlands and Hungary. }\end{array}$ \\
\hline
\end{tabular}

Source: prepared by the author, based on https://www.adesso-group.de/en/adesso-

group/konzern/meilensteine/index.jsp

\subsection{2 \\ Internationalization trajectory}

In its first years of existence, from 1997 to 1999, the company dedicated itself to establishing its bases within German-speaking countries, to which it exported its products. Between the years 2000 and 2006, the company sought growth, expanding in order to offer products to other sectors. In 2007 the company opened its first international front by establishing offices in Switzerland, Luxembourg, and the United Kingdom. That same year it also signed commercial contracts with Russia and Spain. In 2009 Adesso entered the Austrian market through acquisitions, establishing Adesso Austria GmbH. In its initial internationalization phase, Adesso focused on products and solutions and less on consultancy. The company was particularly successful with a content management system called FirstSpirit (Adesso Group, 2009, 2019).

In 2011 the company opened offices in the United States and in 2013, in Turkey. In the United States, its initial intention was only to sell products, but in a short time it also closed contracts for the provision of IT services. In 2018 Adesso adopted the objective of transforming the company into one of the main consultants for specific 
business processes of the IT industry in Central Europe by deciding to focus on strategic internationalization outside the German-speaking market. Adesso's management felt that the company had already grown enough and was now ready to take the next step towards internationalization (Adesso Group, 2013, 2018, 2019).

In 2018 Adesso established subsidiaries in Spain and Bulgaria, and in 2019 in the Netherlands and Hungary. The company had more difficulty entering the Dutch market in 2019. It was a highly diluted market, with around 75,000 existing IT companies, ranging from small companies of up to ten employees to large companies, which were known suppliers of IT services. International expansion has been a key strategic issue for the company since 2018, along with regional expansion. In 2019, in line with its international strategy, Adesso implemented important structural changes and became Societas Europaea (SE). In this new format, the European Forum was created, bringing together employees from Austria, Spain, Switzerland, Turkey, Bulgaria and Germany. It was a platform for the regular exchange of information between subsidiaries, with the objective of initiating transnational guidelines related to issues such as workplace safety, harassment, and equal opportunities (Adesso Group, 2019).

Initially, the internationalization strategy outside the German-speaking market was based on the sale of products. In 2019 sales to customers in Germany grew 17\%, while international sales growth was 33\%, reflecting the new strategy with an international focus. In 2019, Adesso's international facilities were located in five countries (Table 7) in the cities of Amsterdam, Barcelona, Basel, Bern, Boston, Budapest, Istanbul, Jerez de la Frontera, Lausanne, London, Lugano, Madrid, Sofia, Vienna and Zurich.

Table 7 - Adesso SE's Internationalization Trajectory

\begin{tabular}{|c|c|c|c|c|c|}
\hline $\begin{array}{l}\mathbf{2 0 0 7} \\
\text { Switzerland } \\
\text { United } \\
\text { Kingdom }\end{array}$ & $\begin{array}{l}2009 \\
\text { Austria }\end{array}$ & $\begin{array}{l}\mathbf{2 0 1 1} \\
\text { United States }\end{array}$ & $\begin{array}{l}\mathbf{2 0 1 3} \\
\text { Turkey }\end{array}$ & $\begin{array}{l}\mathbf{2 0 1 8} \\
\text { Spain } \\
\text { Bulgaria }\end{array}$ & $\begin{array}{l}\mathbf{2 0 1 9} \\
\text { Netherlands } \\
\text { Hungary }\end{array}$ \\
\hline
\end{tabular}

Source: prepared by the author, based on adesso-annual-report- 2019

Adesso's founder, Volker Gruhn, explained that entry into these countries did not always take place in a fully planned manner, but that once the company becomes installed in a country, it makes a commitment to stay:

"The decision to go to a new country is not always $100 \%$ planned; it is more situational; but once we are there, then we are there for good. Even though it is difficult at first, we strive to make it work. At first it 
was not very easy in Turkey. The Netherlands also had a very difficult initial situation, but we don't like to leave (laughs), so we try to continue."

\title{
4.5.3 \\ Entry into Turkey and the creation of Adesso Turkey
}

Entry into the Turkish market in 2013 was not as easy as expected, according to the company's co-founder, Dr. Volker Gruhn, for whom Adesso's introduction and consolidation in this new market was slower than expected. The original plans foresaw Adesso Turkey operating within the scope of serving the German-speaking market, but at the same time, it was also to be available to the local Turkish market. At the time of entry into Turkey, the company had already gone international and was established in German-speaking countries. Two factors contributed to the motivation for entering Turkey. First, at the time of the decision to enter, it was a country "in turmoil" moving towards westernization. Second, in Germany there was a significant contingent of citizens of Turkish origin. Prof. Rüdiger Striemer, the company's co-founder, who had been responsible for Adesso's initial internationalization phase in Turkey, explained:

\begin{abstract}
"Our desire was to expand the company geographically as well, and we thought about what the next country might be. We chose Turkey - I will explain briefly - for two reasons. First, at that time Turkey was in a completely different political situation, was highly oriented towards the West, and was struggling to become a member of the European Union. So, there was an orientation towards the West - which today is very different - and the economy was in a boom phase at the time - it was very dynamic and grew rapidly. It had a very close connection with Western markets, and that was one of the reasons. The second reason is more of a cultural one. You must think that the cultural difference is huge, and indeed it is. But based on our German history, we could see it in another light. We have many Turkish citizens who live here in Germany, who have studied here, who have acquired their professional experience here, who speak both languages and know both cultures. And that is why we thought that there was really great potential for employees who would make the 'cultural bridge,' that is, who would know both cultures, which in fact proved to be a viable hypothesis."
\end{abstract}

Germany and Turkey have large cultural differences, but they have a significant history of intercultural interaction. Turkey was Germany's ally in the First World War, but remained neutral in the Second World War. In the reconstruction process in Germany, Turkish labor played an important role, mainly in the 1960s and 1970s. As a result, among other factors, the region of Dortmund, located in the Ruhr region, concentrates a large number of citizens of Turkish origin, who, over generations, have acquired both nationalities. Prof. Volker Gruhn, co-founder of Adesso, explained: 
"In the case of Turkey, we considered the fact that we already had the part of the team that spoke German and had access to those who spoke Turkish, because in the Ruhr region, there are many citizens of Turkish origin. At the university, most non-German students are Turkish. That was a reason to think: Now with a rather large group like that we have an opportunity to reconcile the two cultures and, perhaps, to find some people who want to return to Turkey, or at least have people who speak good Turkish and German.”

Rüdiger Striemer, co-founder of Adesso, also comments on the differences between Turkey and Germany in the regulatory dimension:

"Labor legislation in Turkey is completely different from that of Germany, so employees are not as well protected against layoffs as in Germany, but it also means that work in Turkey is more dynamic, so changing jobs is common. It is common to work for one company for half a year and then move on to the next, which is almost impossible in Germany. In Turkey there is more staff turnover. There, an employee can tell you on Friday night that, starting Monday, he or she will be working elsewhere. Fortunately, that does not happen very often, because we also create a good working environment. But we discovered more different things: for example, it is possible for a legal entity to be the general manager of a company in Turkey, which is not possible in Germany, where the general manager can only be an individual. In Turkey our company has two managing directors: one is Burak Bari, the man I hired as managing director at the time, and the other managing director is Adesso SE itself. Bureaucracy is cumbersome in Turkey, and we could say that some regulations and practices are very different. For example, if I had to sign an official document at that time as a representative of the general director, someone would have to go to the registry office with me, and sign three copies of the document with a blue pen; in other words, there are highly bureaucratic processes that do not exist in Germany."

Despite the awareness of these differences, co-founder Striemer explained the philosophy behind international expansion to countries with large institutional differences:

"It is important that we accept from day one that there are these cultural differences. And it is very important not to try to export a German culture to another country, and to get involved with the local culture from day one. Be curious about this culture, try to understand the rules. Try as much as possible to learn how the culture and the rules work."

For the management of Adesso Turkey, the young Turkish executive Burak Bari was chosen. Bari had studied at an Austrian school in Istanbul and after earning a master's degree at the University of Istanbul, he went to study and work in Germany, having worked at two large German companies. When he crossed paths with Adesso, he saw an opportunity to return to his home country and became the CEO of the new company there. Bari explained how his experience with the German language and culture helped with the intercultural vision that was necessary for Adesso's adaptation in Turkey. According to him, cultural differences can be divided into two different 
domains: professional and day-to-day. Bari highlights, in particular, the emotional differences that can affect day-to-day operations as employees become emotionally involved, contrary to what happens in Germany. He highlighted another dimension where there are relevant differences: the long-term orientation in Germany versus the short-term in Turkey. CEO Bari explained:

\begin{abstract}
"The difference in everyday life is simple. We Turks are much more emotional; we are very "moved by emotion." That is an essential difference. Socialization is also a little different, in that we mix work and social life. I mean the job is not so separate; the job goes on one path and family or friends on another... All Turkish employees mix them automatically and that's socially acceptable, compared to Germans. Germans are very process-oriented - of course the emotional is important - but in my experience, work in Germany is not essentially connected with one's social life. There are people who try to combine the two, but there are also a whole lot of people who do not, nor do they want to do it. In Germany, coworkers plan with a long-term vision. I had a good example of vacation planning when I was working in Germany. We did our vacation planning for the year in advance. If I were to tell my Turkish coworkers to plan their holidays like that, they would not be able to manage very well. In Turkey everything is much more dynamic, much more agile, and those are the main differences. At Adesso, we do this concretely. I think this is really exciting - this understanding of the two cultures. I understand local practices and what customers say, but as I said, since my childhood, I have been exposed to the German language at school, and [later] at work in Germany... At Adesso I think we mix well. Adesso Turkey is important and is today one of the largest companies in the group. What we do is that we simply adopt this long-term planning and process orientation, that is, the professionalism on the German side, and the agility and emotions on the Turkish side. We mix it all together. That's it... on the one hand, a Turkish society, one that is more agile and emotional; on the other, the Germans with long-term processes and plans. I think Adesso Turkey has that benefit. This also helps in the market because few companies can create something like that - only those that allow this international culture. But a lot of companies in Turkey were constructed by a family or were created by a founder, so they behave very differently. That really makes us different in the Turkish market. I can tell you that."
\end{abstract}

Bari also highlighted the difficulties faced in entering the Turkish market, including the fact that Adesso Turkey served countries that were part of the so-called DACH region (German speaking countries), which could have caused a certain delay in the recognition of the parent company:

"We have two types of different projects, one of which is to internationalize software for the local market. Brand equity was certainly a big challenge, as was winning new customers for the Adesso brand. It actually took three to four years to build that. It took time to develop this unit, to build a certain customer base, and obtain recognition, which, of course, opens the door more easily. That was one problem. The second challenge was the delivery from Turkey to our customers, with Adesso SE. Adesso had never done that before. Adesso served directly from Germany the entire customer base in the DACH region and we started to supply from Turkey in 2015."

The development of the brand was also a difficult point in the entry of Adesso, previously unknown in Turkey, according to Bari: 
"When you enter a market, you can take brand equity with you. For example, if Apple goes to Africa, it is still Apple. There it has brand equity, recognition. We entered Turkey in 2013; we had very good customers and projects and we could show examples from Germany, but nobody knew what Adesso was. It took years to reach a point where the brand was really recognized. Adesso today has 5,000 employees and is present in 25 countries, but such was not the case at that time, when we were only in the Germanspeaking region and in Turkey. We had to build brand awareness and brand equity."

According to Bari, that was the biggest challenge when the company entered Turkey. The company has undergone other types of adaptations and bureaucratic processes, and procedures required in the country. The accounting, legal and financial procedures differed widely between Germany and Turkey, but did not interfere with Adesso's core product development processes. However, since Bari had been the head of a consulting firm prior to joining Adesso, his knowledge of Turkish bureaucratic processes facilitated Adesso's adaptation in Turkey:

"It was a little different with us, since I had had my own company. When I was studying, I already knew how the Turkish regulatory system worked. That was an advantage. So, the country was not different and unknown to me. Today we also have expert advice available, mainly in the areas of financial and legal accounting (legal matters with clients and employees)."

An important feature and differential of Adesso Turkey is that most of its employees have intercultural competence, that is, there is an expressive knowledge of German culture and language. The vast majority of Adesso Turkey's employees came from Germany and they are Turks who, like Burak Bari, chose to return home. Bari explained that, at the time of the interview, there were no German employees in the company who were not of Turkish origin. The explanation for this was in the difference in the salary structure between employees of the same level in Germany and Turkey. In Germany, the value of the executive's salary in euros cannot be compared to the same salary level as the Turkish executive with the local currency. The same is true in other Eastern European countries, such as Hungary and the Czech Republic, which are important industrial hubs and European suppliers.

"In fact, we have no employees who are $100 \%$ German and currently work in Turkey. I have examples of coworkers who had lived in Germany for 30 years, grew up there, studied there and then returned to Turkey. All of Turkish origin. We have many of these coworkers. They are also very comfortable because you always find part of the German mentality. Again, it would be different at a normal local IT company. You realize that with us the employees feel much more comfortable, of course, because most of them are familiar with the German way of working, the German approach, the German way of thinking; so it works very well for us." 
CEO Bari noted that Adesso Turkey is considered a relatively large company for the Turkish market. In Turkey, the IT market is diluted, with many small independent companies. At the beginning of 2021, Adesso Turkey had 350 employees, and was one of the largest in the segment in the country. The company adopted a higher price that was around $30 \%$ above the market, and it offered products with German quality and service. For Bari, the major disadvantage was the lack of flexibility in the cost structure of products and services:

"The downside is that when the customer says, 'OK, I want to develop this product,' or, 'I would like to have this service' and, of course, 'I want a lower price,' we just won't do that. It ends up being a disadvantage and then we just lose customers."

According to Bari, the German heritage of products and services has been seen as advantageous and recognized by customers. In addition to the differential associated with its German origin, Adesso Turkey adopted flexibility as a local competitive advantage, in addition to the long-term partnership with customers.

\begin{abstract}
"So we try to have a standard, but we allow for a certain agility that is common in the market. The only thing we don't get into is what we call 'quick and dirty,' that is, some hole-plugging solution. We don't do that. But I think we are a little more dynamic, agile, flexible in the general management of the project or service than a $100 \%$ German company would be, perhaps. [...] Another point is the partnership model. It's difficult to find a relationship with local customers like the one we have with Adesso's customers. It goes beyond the customer and supplier relationship; it's much more a partnership relationship, and this is also something that we really like to manage well. [...] At the end of the day, Adesso's differentials are quality, service and product, and what results from that. And that is the beauty that we inherited from Adesso Europa; it is the approach and thinking behind everything we do."
\end{abstract}

Regarding the future of Adesso's internationalization, co-founder Gruhn explained:

"Once we enter a country, the strategy is to grow in this country. The team there already understands this. They [the subsidiaries] are growth-oriented organizations. This is the focus of our planning. Our main focus in internationalization is growth in the countries where we are already located."

\title{
4.5.4 \\ Comparison of the institutional environments of Turkey and Germany
}

This section presents the differences between the institutional environments of Adesso's home country (Germany) and the subsidiary's host country (Turkey) using the World Governance Indicators of the World Bank and the Economic Freedom Index 
(EFI) of the Heritage Foundation to assess the regulatory and normative distances (Tables 8 and 9).

The Worldwide Governance Indicators (WGI) report aggregated and individual governance indicators for more than 200 countries and territories during the 1996-2019 period, for six dimensions of governance: voice and responsibility; political stability and absence of violence / terrorism; government effectiveness; regulatory quality; corruption control. The indicators are composed of the opinion of companies and experts from industrialized and developing countries (World Governance Indicators, 2019). The Economic Freedom Index (EFI) measures the economic freedom of 184 countries based on 12 quantitative and qualitative factors: rule of law (property rights, government integrity, judicial effectiveness); government size (government spending, tax burden, fiscal health); regulatory efficiency (freedom of business, freedom of work, monetary freedom); open markets (commercial freedom, investment freedom, financial freedom). each of the twelve economic freedoms within these categories is rated on a scale of 0 to 100. a country's overall score is derived from the average of these twelve economic freedoms, with equal weight being given to each (Economic Freedom Index, 2021).

Table 8 - WGI Indicators of Regulatory and Normative Distance between Germany and Turkey

\begin{tabular}{|l|l|l|}
\hline Indicators & Germany & Turkey \\
\hline Voice and accountability & 95,07 & 24,63 \\
\hline Political stability and absence of violence/ terrorism & 66,67 & 10,00 \\
\hline Government effectiveness & 93,27 & 54,33 \\
\hline Regulatory quality & 92,31 & 44,71 \\
\hline Control of corruption & 95,19 & 44,71 \\
\hline
\end{tabular}

Sources: World Governance Indicators (WGI) 2019, extracted from

https://info.worldbank.org/governance/wgi/Home/Reports

Table 9 - Economic Freedom in Germany and in Turkey

\begin{tabular}{|l|l|l|}
\hline Indicators & Germany & Turkey \\
\hline Economic Freedom & 72,5 (Mostly Free) & 64 (Moderately Free) \\
\hline
\end{tabular}

Sources: Economic Freedom Index (EFI) 2021, extracted from https://www.heritage.org/index/about

The indicators show substantial differences between Germany and Turkey in terms of regulatory and normative indicators. While Germany is very high in every indicator of regulatory and normative distance, Turkey scores are in the middle of the scale or even in the lower part of the scale (for instance, voice and accountability; and 
political stability and absence of violence/terrorism). In terms of economic freedom, Germany also scores higher ("mostly free"), than Turkey (moderately free), but not as different as in the WGI indicators.

Hofstede's six cultural dimensions were then used to compare the cognitive pillar of institutional distance between Germany and Turkey (Figure 2). Germany and Turkey show remarkable cultural differences, particularly concerning three dimensions: Power Distance, Individualism and Long-term Orientation. Germany's culture is less hierarchical than Turkey's, but Germans score much higher in Individualism, and also present a much higher score in Long-term Orientation than Turkey. In addition, the German society is more masculine, and less prone to uncertainty avoidance. The only cultural dimension in which the two countries present a similar score is Indulgence (both close to the center of the scale).

\section{Germany $\times$ Turkey $\times$}

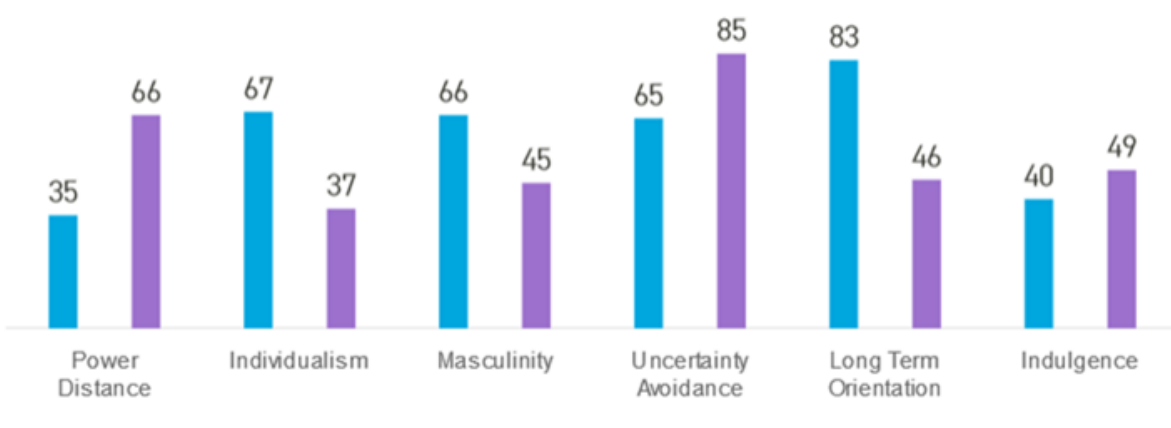

Figure 2 - Comparison of the Hoftsede Dimensions between Germany and Turkey Source: Retrieved from http://www.hofstede-insights.com/

Appendix 1 presents several charts comparing the differences between Germany and other countries where Adesso operated. The charts in Appendix 1 show that the dimensions are quite similar between Germany and other German-speaking countries, such as Austria and Switzerland. Compared to the Netherlands, Germany is more masculine, and to the United States, less individualistic and more long-term oriented. Bulgaria also shows remarkable cultural differences in relation to Germany (as does Turkey), but this country is mainly a production hub for Adesso. 


\section{6 Discussion}

The German company Adesso provides a conceptually interesting case of internationalization to an institutionally distant market. The company exported since its very early years to German-speaking countries in the so-called DACH region. Yet, it took Adesso two decades to establish offices abroad, and two additional years to acquire a foreign firm in Austria and establish its first subsidiary abroad, Adesso Austria. These steps were then followed by a much faster international expansion, until opening a subsidiary in Turkey in 2013. The subsidiary in Turkey was the first outside the German-speaking region. In addition, the company adopted a new business model, since the subsidiary was designed to serve the Turkish market as well as to export to other German-speaking countries. Germany, the home country of Adesso, and Turkey, the host country, share some historical aspects, but are vey different in terms of their institutional environments, as presented in the previous section. Yet the entry in Turkey, despite the institutional gap between the two countries, was considered feasible by the company founders, and even evaluated as no more difficult than entering the Netherlands, a country with a much more similar institutional profile (see Appendix 1).

The interviews showed that both co-founders were fully aware of the high institutional distance between Germany and Turkey, as stated by Rüdiger Striemer: "[...] the cultural difference is huge, and indeed it is." Yet, despite the differences, there were reasons to enter the Turkish market that included both market attractiveness and the perception that the institutional distance was already being reduced by several mechanisms external to the firm or that that the differences could be dealt with, thus making the entry in Turkey a "viable hypothesis."

Table 10 - Reasons to Enter Turkey despite Large Institutional Distance

\begin{tabular}{|l|l|}
\hline Reason & Explanation \\
\hline - Market attractiveness & "the economy was booming" \\
\hline $\begin{array}{l}\text { - Potential reduction of regulatory } \\
\text { institutional distance }\end{array}$ & $\begin{array}{l}\text { "struggling to become a member of the European } \\
\text { Union" }\end{array}$ \\
\hline $\begin{array}{l}\text { - Potential reduction of normative } \\
\text { institutional distance }\end{array}$ & "highly oriented towards the West" \\
\hline $\begin{array}{l}\text { - Use of resources to overcome } \\
\text { cognitive institutional distance }\end{array}$ & $\begin{array}{l}\text { "many Turkish citizens who live here in Germany } \\
{[\ldots] \text { who speak both languages and know both }} \\
\text { cultures [...] who would make the cultural bridge'. }\end{array}$ \\
\hline
\end{tabular}

Source: Interview with co-founder Rüdiger Striemer 
Adesso's management relied on a specific resource, which was the availability of human resources that could establish an institutional "bridge" between the two very different environments. In fact, at the same time differences were recognized, there was a perceived familiarity with the Turkish people, a result of the proximity of a large immigration group living in Germany and particularly in the Ruhr region, and of the permanent contact of the co-founders with Turkish-origin students at the Dortmund Technical University. Historical ties also played a role in the decision, as mentioned by Striemer: "based on our German history, we could see it in another light." These findings suggest that familiarity with a large immigration group (Akcaoglu \& Wehner, 2018) and historical ties (Kedia \& Bilgili, 2015; Liou \& Rao-Nicholson, 2017) do indeed influence the decision to enter an institutionally distant market.

Furthermore, the evidence shows that high institutional distance can be to some extent neutralized by perceived institutional familiarity in a specific dimension - the cognitive (cultural) pillar of institutionalism - in the entry decision. It should be noted, however, that the co-founders were familiar with cultural aspects of the large immigration in their region, and not with Turkey itself. Yet they understood that to take advantage of these resources available in their region would permit to bridge the differences in the regulatory and normative dimensions of the institutional environment, once the firm entered Turkey. Thus, the key dimension was cognitive and not regulatory or normative as Schwens and Kabst (2011) suggested.

To discuss in more depth the research problem addressed here, one has to differentiate two concepts: objective institutional difference and perceived institutional difference. Objective institutional distance is what is measured by the indicators WGI, EFI and Hofstede's cultural dimensions. Yet to understand the real impact of institutional difference, one must consider which are the differences perceived by the firm's top management that are considered relevant to the business operations. The two co-founders and the CEO of Adesso Turkey were asked which were the main differences perceived between the two countries (Table 11).

Table 11 - Perceived Differences between Germany and Turkey

\begin{tabular}{|l|l|l|}
\hline Dimension & German Co-Founders & Turkish CEO \\
\hline Regulatory & - Different firm governance rules & - Different accounting and financial \\
& - Different labor laws (more labor & systems \\
& protection in Germany) & - Different labor laws \\
& - Much more bureaucracy in Turkey & - Different employee compensation \\
\hline
\end{tabular}




\begin{tabular}{|l|l|l|}
\hline Normative & $\begin{array}{l}\text { than in Germany } \\
\text { - Judicial system in Turkey similar to } \\
\text { the German system }\end{array}$ & $\begin{array}{l}\text { systems (higher salaries in Germany } \\
\text { than Turkey) }\end{array}$ \\
\hline $\begin{array}{l}\text { - Differences in permanence in jobs } \\
\text { people remain in their jobs for a long } \\
\text { period of time; more fluid in Turkey, } \\
\text { people change jobs frequently) }\end{array}$ & $\begin{array}{l}\text { - Germans are more oriented towards } \\
\text { processes } \\
- \text { Differences in work practices } \\
\text { more meticulous and perfectionists } \\
\text { (longer work hours, differences in } \\
\text { work time) } \\
\text { - Differences in attitudes towards } \\
\text { and agile }\end{array}$ \\
$\begin{array}{l}\text { vacations (more planning in Germany } \\
\text { and differences of vacation periods) } \\
- \text { Differences in ways of doing } \\
\text { business (more business agreements } \\
\text { based on trust in Germany and based } \\
\text { on contracts in Turkey) }\end{array}$ & \\
\hline Cognitive & $\begin{array}{l}\text { - Turkish culture more creative, more } \\
\text { concerned with design and form than } \\
\text { Germany. }\end{array}$ & $\begin{array}{l}\text { Germans } \\
\text { - Turks are very social } \\
\text { - Work and social life are not separate } \\
\text { realms in Turkey as in Germany. } \\
- \text { Germans have a longer-term vision } \\
\text { compared to Turks }\end{array}$ \\
\hline
\end{tabular}

Source: Interviews with co-founders Rüdiger Striemer and Volker Gruhn, and with Burak Bari, CEO of Adesso Turkey.

Interestingly, differences in perceptions between the two co-founders and the Turkish CEO relate to which differences they consider more relevant. The German cofounders perceive more differences in the regulatory and normative dimensions, while the Turkish CEO focuses more in cognitive (cultural) and normative aspects.

As the firm decided to enter Turkey, a major decision was the choice of the subsidiary's leader. The hiring of Burak Bari was critical for the successful entry of Adesso in Turkey. Born and educated in Turkey, Bari had been exposed since very early in life to the German culture, which made him capable of translating Adesso's organizational culture, processes and routines to the new context. In addition, because he had owned a small firm in Turkey, Bari already had the contacts with suppliers, distributors and even local customers, which facilitated the Adesso's entry into the country, as indicated by Schwens and Kabst (2011). In addition to hiring a Turkish CEO, the staff at the subsidiary was also Turkish. According to co-founder Gruhn, Adesso's Turkish employees were to some extent different from the typical Turk, because most of them had had work experience in Germany, understood the two cultures, besides being younger and technology oriented. 
The new subsidiary faced several difficulties to get established in Turkey, which happened at a slower pace than expected. Yet the reasons for these difficulties were not caused by institutional distance, but rather associated to the fact that Adesso was still a much smaller company than its global competitors that had not yet established brand awareness and brand equity in Turkey. At the end of the process, however, Adesso was able to create competitive advantages by blending the strengths of both cultures, combining products of German origin developed with German processes by Turkish employees, adapted to the country and to local procedures. Excellence in processes, agility, and adaptability, together with a long-term orientation in the relationship with clients, became competitive advantages recognized in the new institutional environment served by Adesso. Therefore, Adesso neither adopted an isomorphic behavior (Salomon $\& \mathrm{Wu}, 2012$ ) nor a deviant behavior (Fortwengel, 2017), but rather blended resources and capabilities from the two environments.

In the case studied, the perception of institutional distance between the two countries increased after the subsidiary was established, due to changing conditions in the political environment. However, although some of the initial conditions that made Turkey a "viable" alternative had changed, and the institutional distance between the two countries was actually perceived to be increasing at the time of fieldwork, rather than being reduced, the changes did not seem to interfere on the decision to keep the Turkish subsidiary. The reasons were, instead of a reduction in perceived distance (an argument used in the Uppsala model concerning psychic distance), (i) knowledge acquired on how to deal with the differences, and (ii) a successful blend of competencies deriving from both countries' characteristics generated a competitive advantage that together with long-term relationship with local clients made Adesso competitive in the Turkish IT segment .

\section{7 \\ Final Remarks}

This article examined the interplay between institutional distance and the perceived institutional familiarity between headquarters and subsidiary in a context of large institutional differences. The choice of the case is justified by the fact that Turkey presents important differences in the institutional environment in comparison with Germany, but which are, in a way, mediated by the high incidence of Turkish 
immigrants living in Germany, which increases German familiarity with some of the aspects of Turkey's institutional environment, in particular those included in the cognitive pillar.

The study provides some interesting contributions to the understanding of the constructs of institutional distance and perceived institutional familiarity, and the interplay between them. First, the study confirms, at a micro level, that historical ties and the proximity of immigration groups in the home country may increase the attractiveness of a host country for foreign direct investment in the country of origin of these immigrants (Gheasi, Nijkamp \& Rietveld, 2013; Javorcik et al., 2011). Second, the findings suggest that perceived familiarity has a potential neutralizing impact on institutional distance concerning market entry (in this case, with a greenfield investment). Third, the study shows that the firm may use members of the immigrant group to staff the subsidiary and thus build an institutional "bridge" capable of translating differences and blending capabilities, even when the institutional distance between the two countries is increasing. Thus, the results show the importance of being open to the differences between the two countries, not with the intention of ending differences, but of adapting to them. Fourth, although the results show that perceived institutional familiarity manifested itself in the cognitive pillar, it is reasonable to suppose that it can happen in any of the three pillars. Moreover, perceived institutional familiarity in one pillar may help to bridge differences in the other two pillars. In addition to the limitations associated to method, the case study, the study uses a limited number of interviews - three top managers and one government institutional manager. However, secondary data helped to achieve triangulation, guaranteeing the consistency and reliability of the data presented in the case.

The study offers several opportunities for further research. The interplay between institutional familiarity and institutional distance needs to be investigated in other contexts, other industries and smaller-sized entrepreneurial firms (Keupp \& Gassmann, 2009) to understand whether the phenomenon presents different specificities. 


\section{8 References}

Abdi, M., \& Aulakh, P. S. (2012). Do country-level institutional frameworks and interfirm governance arrangements substitute or complement in international business relationships?. Journal of International Business Studies, 43(5), 477-497.

Adesso Group (2009, 2013, 2018, 2019) Annual Report. Germany, Adesso. Available at: https://www.adesso-group.de/en/investorrelations/veroeffentlichungen/financial-reports/index.jsp

Akcaoglu, E., \& Wehner, R. (2018). German FDI in Turkey: an analysis under the recent developments. Würzburg International Business Forum Conference Proceedings. University of Applied Sciences Würzburg-Schweinfurt, p. 105-112. Available at: file://C:/Users/Downloads/WIBF\%20IBC2018\%20CONFERENCE\%20PROCEEDIN GS\%20BOOK\%20(4).pdf

Ando, N., \& Paik, Y. (2013), Institutional distance, host country and international business experience, and the use of parent country nationals. Human Resource Management Journal, 23, 52-71.

Arslan, A. \& Larimo, J. (2010). Ownership strategy of multinational enterprises and the impacts of regulative and normative institutional distance: Evidence from Finnish foreign direct investments in Central and Eastern Europe. Journal of East-West Business, 16(3), 179-200.

Bae, J.-H. and Salomon, R. (2010). Institutional distance in international business research. In Timothy, D., Torben, P. and Laszlo, T. (Ed.) The Past, Present and Future of International Business \& Management(Advances in International Management, Vol. 23), Emerald Group Publishing Limited, Bingley, pp. 327-349.

Bell, J., McNaughton, R., \& Young, S. (2001). 'Born-again global' firms: An extension to the 'born global' phenomenon. Journal of International Management, 7(3), 173-189.

Bloodgood, J. M., Sapienza, H. J., \& Almeida, J. G. (1996). The internationalization of new high-potential US ventures: Antecedents and outcomes. Entrepreneurship Theory and Practice, 20(4), 61-76.

Buch, C. M., Kleinert, J., \& Toubal, F. (2003). Determinants of German FDI: New evidence from micro-data. Deutsche Bundesbank, Economic Research Centre 
Discussion Paper No. 09/03, March 2003. Available at SSRN: https://ssrn.com/abstract=392681 or http://dx.doi.org/10.2139/ssrn.392681

Buch, C.M., Kleinert, J. \& Toubal, F, (2006). Where enterprises lead, people follow? Links between migration and FDI in Germany. European Economic Review, 50(8), 2017-2036.

Boter, H., \& Holmquist, C. (1996). Industry characteristics and internationalization processes in small firms. Journal of Business Venturing, 11(6), 471487.

Crick, D., \& Spence, M. (2005). The internationalisation of 'high performing' UK high-tech SMEs: A study of planned and unplanned strategies. International Business Review, 14(2), 167-185.

Deloitte (2019). Data Nation Germany - The German Technology Sector, from hardware to software and services. Deloitte. Available at: https://www2.deloitte.com/de/de/pages/trends/study-german-technology-sector.html

Economic Freedom Index (EFI)(2021). Heritage Foundation. Available at: https://www.heritage.org/index/about

Eisenhardt, K. M., \& Graebner, M. E. (2007). Theory building from cases: Opportunities and challenges. Academy of Management Journal, 50(1), 25-32.

Elango, B., Lahiri, S., \& Kundu, S.K. (2013). Ownership choice in hightechnology acquisitions. $R \& D$ Management, 43(5), 501-516.

Eriksson, K., Johanson, J., Majkgard, A., \& Sharma, D. D. (1997). Experiential knowledge and cost in the internationalization process. Journal of International Business

Studies, 28(2), 337-360.

Estrin, S., Baghdasaryan, D., \& Meyer, K. E. (2009). The impact of institutional and human resource distance on international entry strategies. Journal of Management Studies, 46(7), 1171-1196.

Felbermayr, G. J., \& Toubal, F. (2010). Cultural proximity and trade. European Economic Review, 54(2), 279-293.

Fiorini, M., Giovannetti, G., Lanati, M., Santi, F. (2021). Asymmetric cultural proximity and greenfield foreign direct investment. World Economy, 1-32. https://doi.org/10.1111/twec.13088 
Gaur, A.S., \& Lu, J.W. (2007). Ownership strategies and survival of foreign subsidiaries: Impacts of institutional distance and experience. Journal of Management, 33(1), 84-110.

Ghauri, P. (2004). Designing and conducting case studies in international business research. In R. Marschan-Piekkari \& Welch, C. (Eds.) Handbook of Qualitative Research Methods for International Business, (pp.109-124). Cheltenham, UK: Edward Elgar.

Gheasi, M., Nijkamp, P., \& Rietveld, P. (2013). Migration and foreign direct investment: education matters. The Annals of Regional Science, 51(1), 73-87.

Global Competitiveness Report (GCR) (2020). World Economic Forum. Available at: https://www.weforum.org/reports/the-global-competitiveness-report-2020

Hernández, V., \& Nieto, M. J. (2015). The effect of the magnitude and direction of institutional distance on the choice of international entry modes. Journal of World Business, 50(1), 122-132.

Hofstede, G. (1980). Culture's Consequences: International Differences in Work-Related Values. Newbury Park, CA: Sage.

Hofstede, G. (2011). Dimensionalizing cultures: The Hofstede model in context. Online Readings in Psychology and Culture, 2(1), 2307-0919.

Hofstede, G., \& Bond, M. H. (1988). The Confucius connection: From cultural roots to economic growth. Organizational Dynamics, 16(4), 5-21.

Hofstede, G., Hofstede, G. J., \& Minkov, M. (2010). Cultures et organisations: Nos programmations mentales. Paris: Pearson Education France.

Hofstede, G. (1991). Empirical models of cultural differences. In N. Bleichrodt \& P. J. D. Drenth (Eds.), Contemporary Issues in Cross-Cultural Psychology (p. 4-20). Swets \& Zeitlinger Publishers.

House, R., Javidan, M., Hanges, P., \& Dorfman, P. (2002). Understanding cultures and implicit leadership theories across the globe: an introduction to project GLOBE. Journal of World Business, 37(1), 3-10.

Hutzschenreuter, T., Kleindienst, I., \& Lange, S. (2016). The concept of distance in international business research: a review and research agenda. International Journal of Management Reviews, 18, 160-179.

Javorcik, B. S., Özden, Ç., Spatareanu, M., \& Neagu, C. (2011). Migrant networks and foreign direct investment. Journal of Development Economics, 94(2), 231-241. 
Johanson, J., \& Vahlne, J. E. (1977). The internationalization process of the firm - a model of knowledge development and increasing foreign market commitments. Journal of International Business Studies, 8(1), 23-32.

Kedia, B. L., \& Bilgili, T. V. (2015). When history matters: The effect of historical ties on the relationship between institutional distance and shares acquired. International Business Review, 24(6), 921-934.

Keupp, M. M., \& Gassmann, O. (2009). The past and the future of international entrepreneurship: a review and suggestions for developing the field. Journal of Management, 35(3), 600-633.

Kogut, B., \& Zander, U. (1992). Knowledge of the firm, combinative capabilities, and the replication of technology. Organization Science, 3(3), 383-397.

Kostova, T., Beugelsdijk, S., Scott, W. R., Kunst, V. E., Chua, C. H., \& van Essen, M. (2020). The construct of institutional distance through the lens of different institutional perspectives: Review, analysis, and recommendations. Journal of International Business Studies, 51(4), 467-497.

Kostova, T., \& Zaheer, S. (1999). Organizational legitimacy under conditions of complexity: The case of the multinational enterprise. Academy of Management Review, 24(1), 64-81.

Li, J., Jiang, F. \& Shen, J. Institutional distance and the quality of the headquarters-subsidiary relationship: The moderating role of the institutionalization of headquarters' practices in subsidiaries. International Business Review, 55(2), 589-603.

Liou, R.S., Chao, M. C.-H. \& Yang, M. (2016). Emerging economies and institutional quality: Assessing the differential effects of institutional distances on ownership strategy. Journal of World Business, 51(4), 600-611.

Liou, R-S., \& Rao-Nicholson, R. (2017). Out of Africa: The role of institutional distance and host-home colonial tie in South African Firms' post-acquisition performance in developed economies. International Business Review, 26(6), 1184-1195.

North, D. C. (1990). A transaction cost theory of politics. Journal of Theoretical Politics, 2(4), 355-367.

Pedersen, T., \& Petersen, B. (2004). Learning about foreign markets: are entrant firms exposed to a "shock effect"?. Journal of International Marketing, 12(1), 103-123.

Quer, D., Rienda, L., Andreu, R., \& Miao, S. (2019). Host country experience, institutional distance and location choice of Chinese MNEs: The moderating effect of government official visits. Cross Cultural \& Strategic Management, 26(1), 24-45. 
Rana, M. B., \& Nipa, F. S. (2019). Entrepreneurship in an institutionally distant context: Bangladeshi Diaspora Entrepreneurs in Denmark. In Diaspora Networks in International Business (pp. 529-555). Springer, Cham.

Salomon, R., \& Wu, Z. (2012). Institutional distance and local isomorphism strategy. Journal of International Business Studies, 43(4), 343-367.

Sapienza, H. J., Autio, E., George, G., \& Zahra, S. A. (2006). A capabilities perspective on the effects of early internationalization on firm survival and growth. Academy of Management Review, 31(4), 914-933.

Schwens, C., \& Kabst, R. (2011). Internationalization of young technology firms: A complementary perspective on antecedents of foreign market familiarity. International Business Review, 20(1), 60-74.

Scott, W. R. (1995). Institutions and Organizations: Foundations for organizational science. London: Sage.

Schäffler, J., Hecht, V. \& Moritz, M. (2017). Regional determinants of German FDI in the Czech Republic: new evidence on the role of border regions. Regional Studies, 51(9), 1399-1411.

Shirodkar, V., \& Konara, P. (2017). Institutional distance and foreign subsidiary performance in emerging markets: Moderating effects of ownership strategy and hostcountry experience. Management International Review, 57(2), 179-207.

Singh, J. V., Tucker, D. J., \& House, R. J. (1986). Organizational legitimacy and the liability of newness. Administrative Science Quarterly, 31, 171-193.

Slangen, A. H., \& Beugelsdijk, S. (2010). The impact of institutional hazards on foreign multinational activity: A contingency perspective. Journal of International Business Studies, 41(6), 980-995.

Tung, R., \& Verbeke, A. (2010). Beyond Hofstede and GLOBE: Improving the quality of cross-cultural research. Journal of International Business Studies, 41, 12591274.

Van Den Waeyenberg, S. \& Hens, L. (2012). Overcoming institutional distance: Expansion to base-of-the-pyramid markets. Journal of Business Research, 65(12), 1692-1699.

Van Hoorn, A., \& Maseland, R. (2016). How institutions matter for international business: Institutional distance effects vs institutional profile effects. Journal of International Business Studies, 47, 374-381. 
Wang, J., Liu, X., Wei, Y., \& Wang, C. (2014). Cultural proximity and local firms' catch up with multinational enterprises. World Development, 60, 1-13.

World Bank's World Governance Indicators (WGI) (2019), World Bank's. Available at: https ://info.worldbank.org/governance/wgi/Home/Reports

World Competitiveness Yearbook (WCY)(2020. IMD. Available at: / https://www.imd.org/wcc/world-competitiveness-center/

Zaheer, S. (1995). Overcoming the liability of foreignness. Academy of Management Journal, 38(2), 341-363.

Zhu, H., Xia, J., \& Makino, S. (2015). How do high-technology firms create value in international M\&A? Integration, autonomy and cross-border contingencies. Journal of World Business, 50(4), 718-728.

\section{9}

\section{Appendix 1 - Hofstede's Cultural Dimensions - Other Countries}

\section{Germany $\times$ Switzerland $\times$}

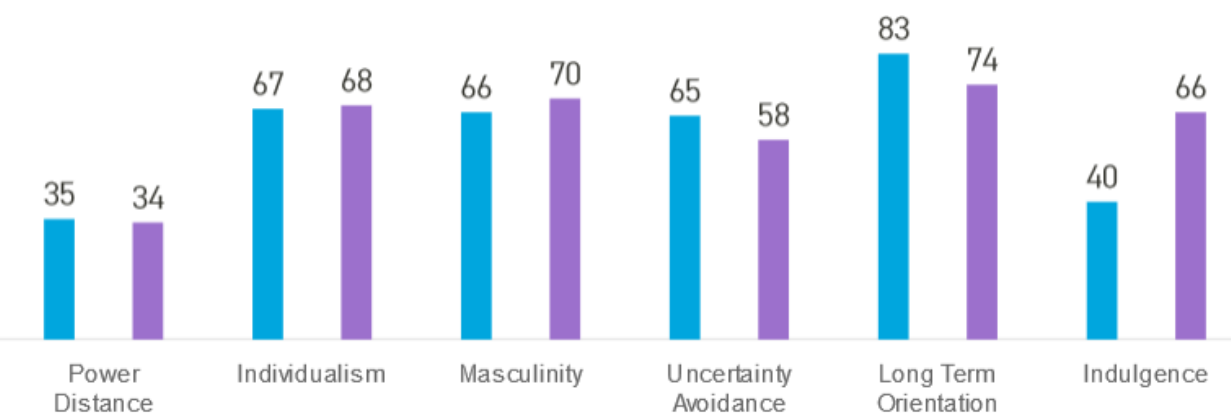

Figura 1a - Comparativo de Hoftsede, dos países de entrada da Adesso SE (Alemanha e Suiça) Fonte: elaborado pelo autor, com base em https ://www.hofstede-insights.com/ 


\section{Germany $\times$ United Kingdom $\times$}

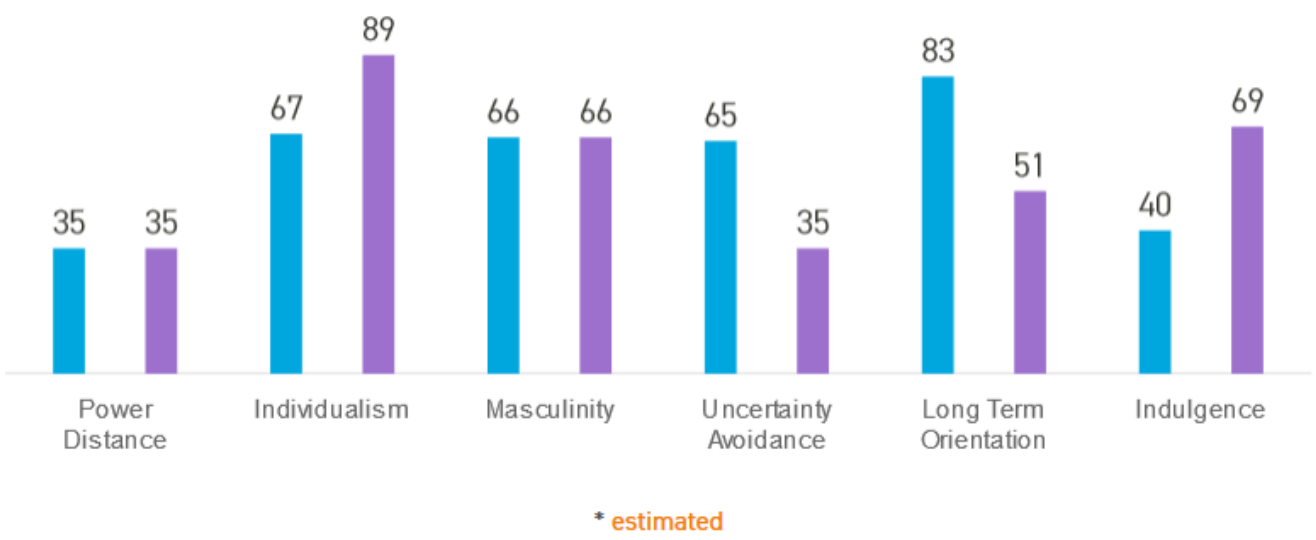

Figura 1b - Comparativo de Hoftsede, dos países de entrada da Adesso SE (Alemanha e Reino Unido) Fonte: elaborado pelo autor, com base em https://www.hofstede-insights.com/

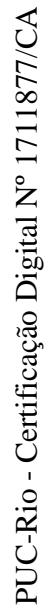

\section{Austria x Germany x}

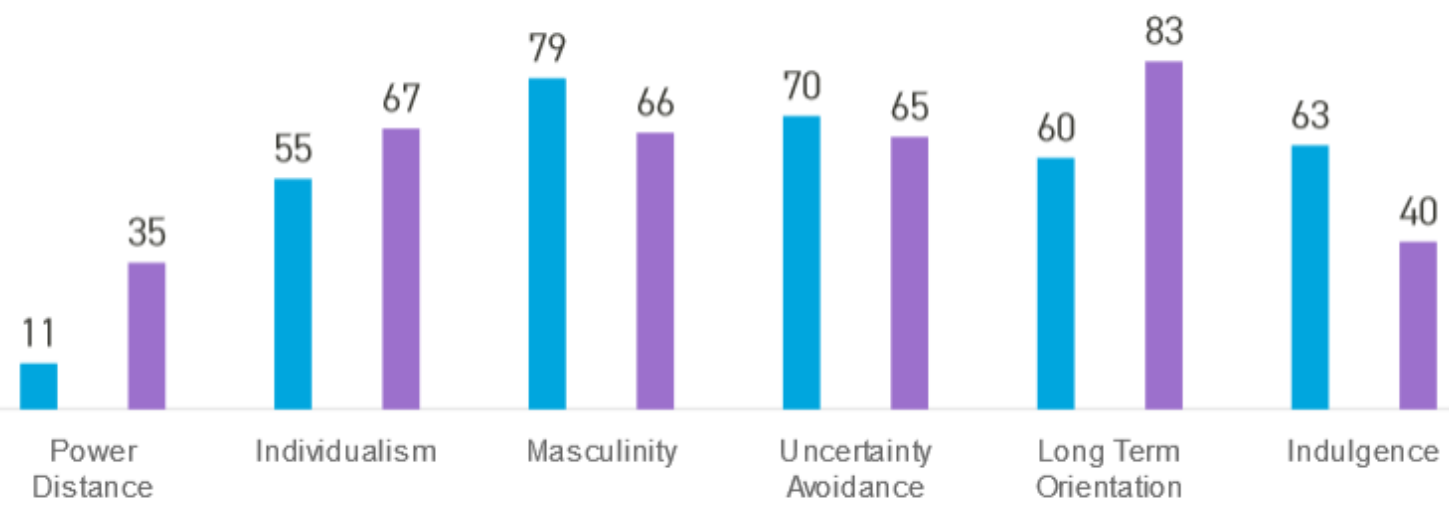

Figura 1c - Comparativo de Hoftsede, dos países de entrada da Adesso SE (Alemanha e Áustria) Fonte: elaborado pelo autor, com base em https://www.hofstede-insights.com/ 


\section{Germany $\times$ United States $\times$}

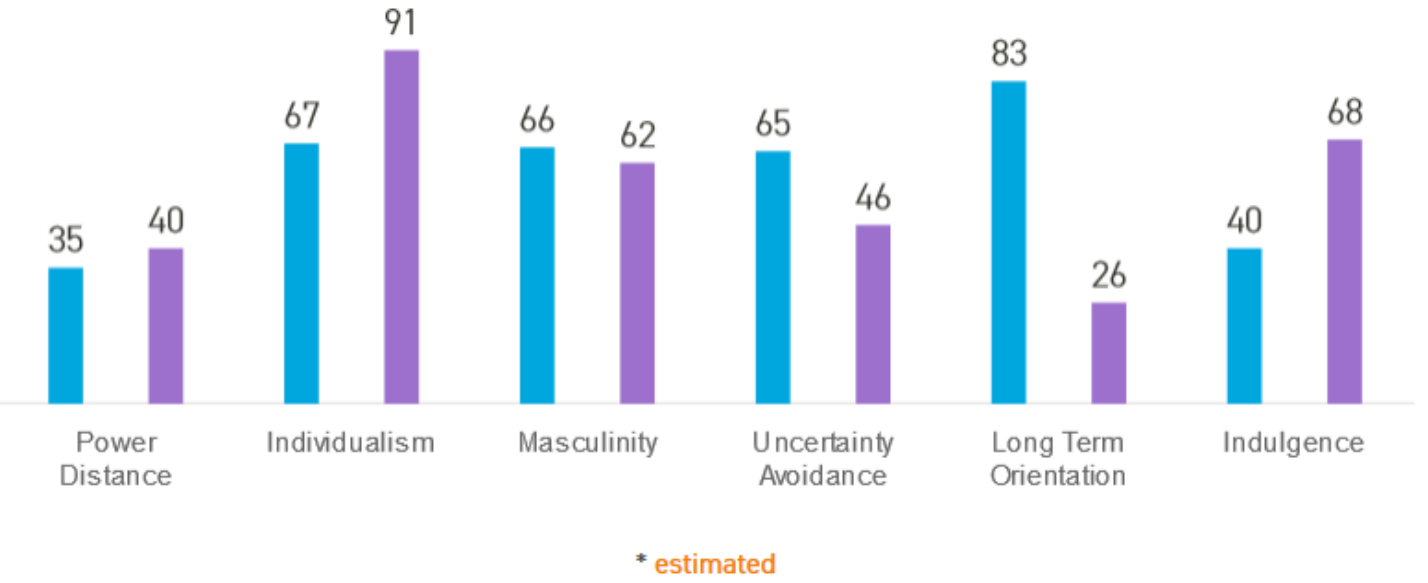

Figura 1d-Comparativo de Hoftsede, dos países de entrada da Adesso SE (Alemanha e Estados Unidos) Fonte: elaborado pelo autor, com base em https://www.hofstede-insights.com/

\section{Germany $\times$ Spain $\times$}

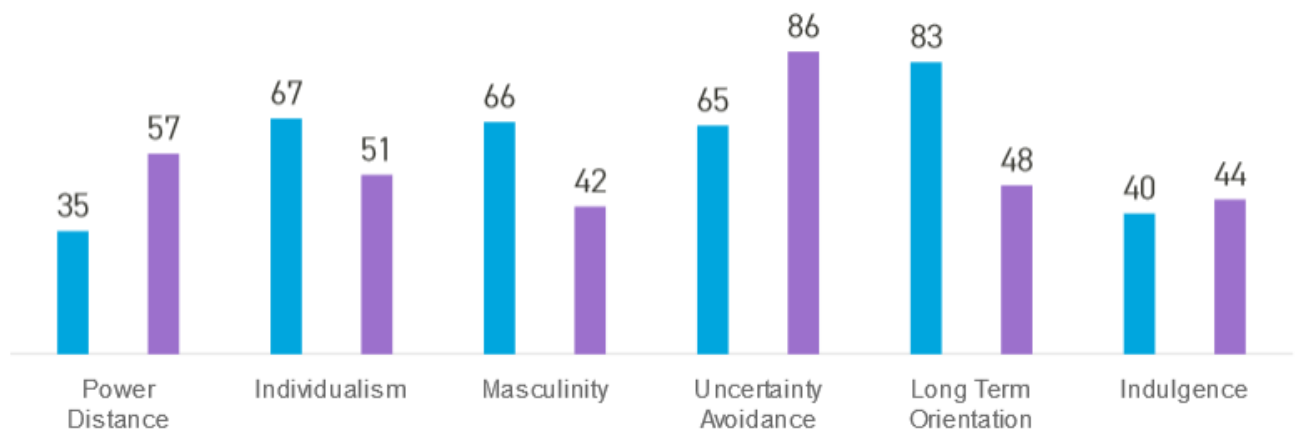

Figura 1e - Comparativo de Hoftsede, dos países de entrada da Adesso SE (Alemanha e Espanha) Fonte: elaborado pelo autor, com base em https://www.hofstede-insights.com/ 


\section{Bulgaria $\times$ Germany $\times$}

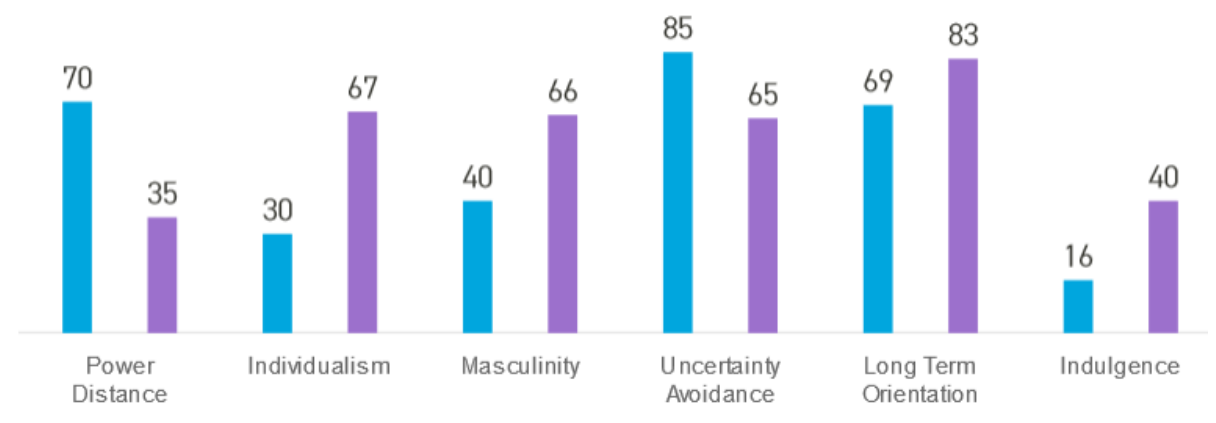

Figura 1f - Comparativo de Hoftsede, dos países de entrada da Adesso SE (Alemanha e Bulgaria) Fonte: elaborado pelo autor, com base em https://www.hofstede-insights.com/

\section{Germany $\times$ Hungary* $\times$}

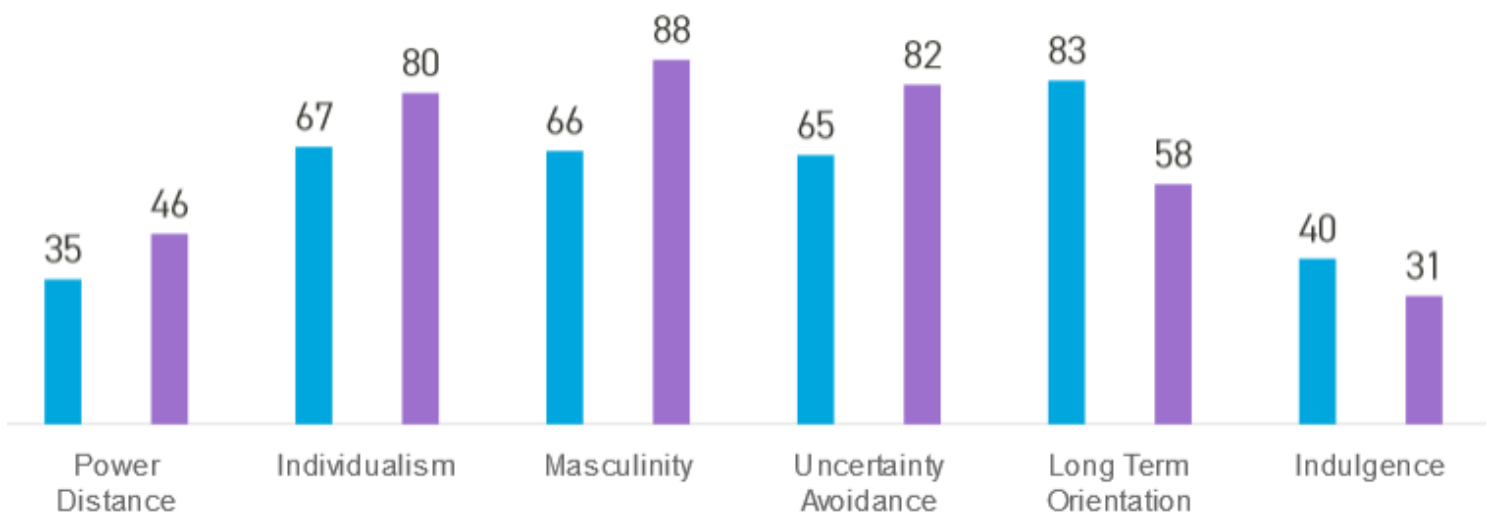

Figura 1g - Comparativo de Hoftsede, dos países de entrada da Adesso SE (Alemanha e Hungria) Fonte: elaborado pelo autor, com base em https://www.hofstede-insights.com/ 


\section{Germany $\times$ Netherlands $\times$

80

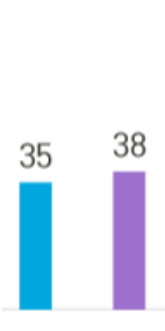

Power Distance

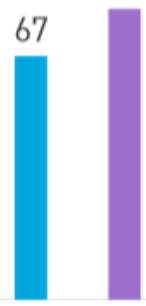

Individualism

83

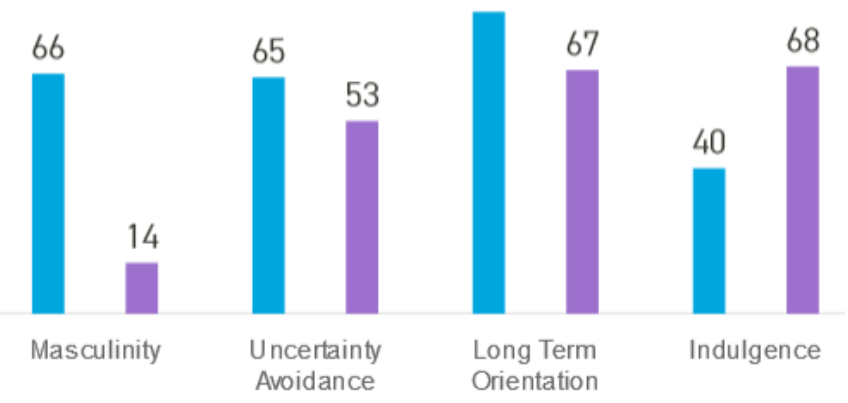

Figura 1h - Comparativo de Hoftsede, dos países de entrada da Adesso SE (Alemanha e Holanda) Fonte: elaborado pelo autor, com base em https://www.hofstede-insights.com/ 


\section{Conclusion}

This chapter presents an overview of the thesis, summarizes the contributions and presents suggestions for future research.

\section{1 \\ Thesis Overview and Cross-Case Comparison}

Institutional theory has become a major theoretical perspective in the field of International Business, due to the understanding that the institutional environment of the home and of the host country play a critical role in the firm's entry and operation in a foreign market. The area of International Entrepreneurship, which focuses on the internationalization of entrepreneurial firms and comparative entrepreneurship, has not given the same attention to institutional theory. However, home and host country institutional environments are critical for the internationalization of entrepreneurial firms. Therefore, this thesis examined international entrepreneurship under the perspective of institutional theory.

This thesis presents a bibliometric review of the literature on international entrepreneurship that uses institutional theory, covering the period between 2008 and 2020, and two in-depth longitudinal case studies. Although there are several literature reviews covering the field of international entrepreneurship, only one focused on studies that used institutional theory, but covered only articles published until 2008. Therefore, this thesis contributed to fulfill this gap. The bibliometric study examined a total of 65 articles, of which a large number looked at comparative entrepreneurship issues, and a smaller number focused on the internationalization of entrepreneurial firms. Nevertheless, more recent studies seem to dedicate a growing attention to institutional issues impacting the internationalization of entrepreneurial firms.

The empirical part of this thesis consists of two case studies reported in two different chapters. The two separate cases helped to achieve a deeper understanding of different aspects of the effects of home country institutions on the firm 
internationalization process of mature entrepreneurial firms. Regarding case similarities, both firms have reached a leading position in the software industry in a world region (Latin America and Central Europe); and both presented similar core business and products. Both firms only started international activities close to a decade after their inception, when they were already mature firms. Both show the characteristics of entrepreneurial firms. By 2020, the two firms were large, but only relatively large when compared to industry standards. Yet Stefanini presented a faster growth than Adesso. In fact, Stefanini's first acquisition in the U.S. was almost the size of Adesso at the time of this study. Table 1 compares the characteristics of the two companies in 2019.

Table 1 - Comparison of the characteristics of Stefanini IT and Adesso SE

\begin{tabular}{|l|c|c|}
\hline \multicolumn{1}{|c|}{ Firm Characteristic } & Stefanini IT & Adesso SE \\
\hline Year of inception & 1987 & 1997 \\
\hline Internationalization & 1996 (9 years later) & 2007 (10 years later) \\
\hline Total sales & US\$ 786.596.397 (2020) & U\$S 534 million (2019) \\
\hline Main product lines & $\begin{array}{c}\text { Applications, ITO, BPO, } \\
\text { Software Solutions, } \\
\text { Business }\end{array}$ & $\begin{array}{c}\text { Business processes and } \\
\text { customized software } \\
\text { solutions, IT services }\end{array}$ \\
\hline No. of employees & 25.000 & 4.033 \\
\hline No. of employees in the country & 13.000 & 3.328 \\
\hline No. of employees abroad & 12.000 & 705 \\
\hline Ownership & Privately held & Public \\
\hline
\end{tabular}

In 2019, Stefanini had around 25,000 employees worldwide, almost half of them outside Brazil, while Adesso had a total of 3,328 employees in Germany and 705 abroad. Despite this difference, Adesso is considered a large company in the sector in its region, but not in comparison with the major IT companies worldwide. Considering specifically the internationalization trajectories of the two firms, the comparison shows that while both companies started their international expansion following a step-by-step gradual commitment (Johanson \& Vahlne, 1977, 2009), their strategies started to radically differ after some years of international experience. While Adesso expanded mainly by organic growth, Stefanini at a given moment in its trajectory adopted acquisitions as a mechanism to gain legitimacy and accelerate growth.

Why did these firms differ in their strategy pace after similar initial international trajectories? The case studies show very clearly that the main reason relates to the type of problems they faced when entering specific international markets: Stefanini in the 
U.S. and Adesso in Turkey. Both firms did not have a brand reputation when they entered these host markets, but their home country reputation strongly differed. Although Germany is not considered a leader in innovation and trends in the IT segment, the country has a strong reputation in terms of quality and processes. In Brazil, the IT segment is dominated by large multinational firms and it is very oriented towards the domestic market with few domestic companies having internationalized. And while German firms benefit from the home country positive image, Brazilian firms are impacted by the home country's lack of reputation as a supplier of technology abroad and by negative national stereotypes.

Therefore, the two firms faced different problems. While Adesso had to develop brand awareness in a country (Turkey) where Germany already had a strong reputation, Stefanini needed to overcome the negative impact of its home country image and national stereotypes. Both firms, however, had to adopt strategies to overcome liabilities of foreignness and of outsidership. Adesso faced very high institutional distance to the host market, but the home country institutional environment (Germany) already provided the answer, with a large number of individuals with dual citizenship and bilingual. So, Adesso responded by building an institutional "bridge" using members of the immigrant group to staff the new subsidiary in Turkey in order to reduce the impact of institutional distance. This solution was probably better than an acquisition in Turkey, because Adesso did not have to face the problems of integration of two companies from very different institutional environments in the three pillars (regulatory, normative and cognitive). By doing so, Adesso addressed the liability of foreignness and the liability of outsidership simultaneously. As to Stefanini, the strategic response required to overcome more challenging problems. Stefanini responded by acquiring a large local company with the purpose of gaining legitimacy, overcoming institutional voids, and neutralizing the liabilities of foreignness, emergingness and outsidership. In fact, all the different issues associated to the liabilities faced by the firm were resolved with the acquisition, which permitted to distance the firm from the home country's image. 


\section{2 Contributions of the Study}

The study provides several contributions to the understanding of international entrepreneurship using an institutional perspective.

First, the study provides a review of the bulk of the literature on international entrepreneurship using an institutional perspective, identifying the main themes that emerged in the last years. Although there is a concentration on comparative entrepreneurship studies, the review also shows that several themes have emerged more recently, including those related to the strategic behavior of entrepreneurial firms when facing institutional challenges in their internationalization, to firm's resources and capabilities to internationalize, and to the outcomes of internationalization.

Second, the empirical studies look specifically at the long-term international trajectory of mature entrepreneurial firms, one from an emerging market and the other from an advanced economy. The results help to improve our knowledge of the poorly understood linkage between home country institutions and entrepreneurial internationalization (Estrin et al., 2016; Marano et al., 2016). The analysis and comparison of these two successful firms may contribute to the debate on how home country institutions influence internationalization within different contexts of emerging and developed markets. The evidence provided show unequivocally the influence of home country institutions on the internationalization strategy chosen by each firm.

Third, the study addresses specifically the specificities of the different types of liabilities and delineates processes of gaining legitimacy by an emerging market multinational. This study's in-depth, longitudinal investigation provides a variety of details on these issues.

Fourth, the study examines the interplay between institutional distance and institutional familiarity, providing some evidence on the nature and outcomes of these two constructs when establishing a subsidiary in a country with large institutional distance from the home country.

Fourth, another contribution refers to additional support to the claim that acquisitions have been often preferred by emerging market firms; in the case studied, as a mechanism not only to overcome liabilities and gain legitimacy but specifically to distance the firm from a negative country-of-origin image in a specific industry. 


\section{3 Suggestions for Future Research}

The study offers several opportunities for further research. There is still a broad space for research that contributes to the understanding of the internationalization of entrepreneurial firms. The review of the literature identified a limited number of studies that examines home country factors and focuses on the challenges faced by entrepreneurial firms entering host countries with different institutional environments. The interplay between institutional familiarity and institutional distance needs to be investigated in other institutional environments, other industries and smaller-sized entrepreneurial firms to understand whether the phenomenon presents different manifestations and specificities in other contexts.

Further research could provide additional evidence about the specificities of liabilities of foreignness, emergingness and outsidership faced by firms in different industries of emerging economies, particularly by smaller-sized entrepreneurial firms. A quantitative study with entrepreneurial high-tech firms originating from countries whose country image is not favorable to technology should provide the opportunity to test whether the legitimation strategies identified in this study are similar in other contexts and identify new patterns.

\section{4 \\ References}

Estrin, S., Meyer, K. E., Nielsen, B. B., \& Nielsen, S. (2016). Home country institutions and the internationalization of state owned enterprises: A cross-country analysis. Journal of World Business, 51(2), 294-307.

Marano, V., Arregle, J. L., Hitt, M. A., Spadafora, E., \& Van Essen, M. (2016). Home country institutions and the internationalization-performance relationship: A meta-analytic review. Journal of Management, 42(5), 1075-1110. 